\title{
Magnetostratigraphy and magnetic susceptibility of the best developed Pleistocene loess-palaeosol sequences of Ukraine: implications for correlation and proposed chronostratigraphic models
}

\author{
Dmytro V. HLAVATSKY ${ }^{1, *}$ and Vladimir G. BAKHMUTOV ${ }^{1}$
}

1 National Academy of Sciences of Ukraine, Institute of Geophysics, Akademika Palladina Ave. 32, 03142 Kyiv, Ukraine

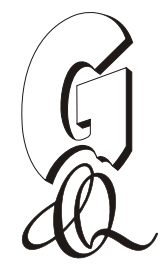

\begin{abstract}
Hlavatskyi, D.V., Bakhmutov, V.G., 2020. Magnetostratigraphy and magnetic susceptibility of the best developed Pleistocene loess-palaeosol sequences of Ukraine: implications for correlation and proposed chronostratigraphic models. Geological Quarterly, 64 (3): 723-753, doi: 10.7306/gq.1544
\end{abstract}

Associate Editor: Jacek Grabowski

We provide a revised magnetostratigraphy and magnetic susceptibility stratigraphy of the most complete and thickest (to nearly $60 \mathrm{~m}$ ) loess-palaeosol sequences in Ukraine spanning the past $1 \mathrm{My}$ : the Roksolany (Black Sea Lowland) and Vyazivok (Dnieper Lowland) sections. The Matuyama-Brunhes boundary has been detected in both sequences in stratigraphically different palaeosol units according to current regional chronostratigraphic schemes. Hypotheses of a large magnetic lock-in depth at Vyazivok and lithostratigraphic incompleteness at Roksolany do not resolve this inconsistency. Instead, new chronostratigraphic models following the Chinese loess designation system, which are supported by correlation of the magnetic susceptibility records with the marine isotope record and established magnetostratigraphic control points, are proposed. We conclude that the Matuyama-Brunhes reversal in the Roksolany and Vyazivok sections belongs to the same palaeosol unit, the Shyrokyne (according to our nomenclature, the U-S7), which corresponds to MIS 19. This novel interpretation resolves the inconsistency of the stratigraphic position of the Matuyama-Brunhes boundary in Ukrainian loess, ends long-standing debate regarding the chronostratigraphy of the Roksolany section, and allows precise correlation of the most representative loess-palaeosol sequences of Ukraine with those in the Danube Basin and the Chinese Loess Plateau. It is considered that the Roksolany Tephra in MIS 6 loess unit can be related to the L2 Tephra which is widely distributed in southeastern European loess records and lacustrine archives. In the light of our results, the Roksolany sequence may serve as a national lectostratotype of the Middle Zavadivka (U-L4) loess unit corresponding to MIS 10. Additionally, a generalized pedostratigraphic column of the past $1 \mathrm{My}$ for central and southern Ukraine has been constructed and correlated with the Hungarian, Serbian and Chinese loess stratigraphies, as well as with the marine isotope record down to MIS 25.

Key words: Pleistocene, loess, magnetostratigraphy, magnetic susceptibility, Matuyama-Brunhes boundary, Ukraine.

\section{INTRODUCTION}

Loess deposits are unique continental successions of the Quaternary. They contain one of the most complete records of global climate change of this geological period, particularly of glaciations and interglaciations of the last million years, and are widespread, mostly at intermediate latitudes of the Northern Hemisphere. Loess sequences consist of loess-palaeosol alternations where loess layers are relatively fresh aeolian deposits formed during colder climate periods, whereas palaeosols develop on a loess layer by pedogenic processes during warmer

\footnotetext{
* Corresponding author, e-mail: hlavatskyi@gmail.com
}

Received: February 18, 2020; accepted: May 29, 2020; first published online: September 1, 2020 and wetter conditions. Palaeoclimatic studies (Heller and Liu, 1984; Kukla et al., 1988; Ding et al., 1994, 2002; Jordanova and Petersen, 1999; Lu et al., 1999; Heslop et al., 2000; Rousseau et al., 2001; Jordanova et al., 2007; Buggle et al., 2009; Marković et al., 2011; Fitzsimmons et al., 2012; Bolshakov, 2017 and others), carried out on key loess-palaeosol sequences of the Chinese Loess Plateau (CLP), Danube Basin and East European Plain, have shown that rock magnetic palaeoenvironmental proxies, primarily magnetic susceptibility (MS), display strong similarities and can be correlated with the marine oxygen isotope (marine isotope stage, MIS) scale (Shackleton et al., 1990; Lisiecki and Raymo, 2005).

Continental loess deposits also record geomagnetic field behaviour. The Matuyama-Brunhes boundary (MBB), the last palaeomagnetic reversal, which occurred 780 ka ago, in interglacial MIS 19 (Shackleton et al., 1990; Tauxe et al., 1996), is recorded in a wide range of geological archives (Singer et al., 2005; Liu et al., 2015). The Matuyama-Brunhes transition is the most closely studied polarity reversal and an important calibra- 
tion point on the geological timescale, connecting sedimentary and volcanic stratigraphies.

Ukraine hosts the largest European loess area (Haase et al., 2007). It belongs to the East European loess province located in the central part of the Eurasian loess belt (Veklich, 1968; Velichko, 1990). The regional Pleistocene stratigraphy has been defined through multidisciplinary studies, including research in pedostratigraphy, pedology, mineralogy, palynology and malacology (Krokos, 1932; Veklich et al., 1967, 1984a, 1993; Sirenko and Turlo, 1986; Gerasimenko, 2006; Matviishyna et al., 2010; Gozhyk, 2012; Sirenko, 2019 and many others). However, clear general stratigraphic correlation of the best developed loess-palaeosol sequences of Ukraine with other sequences in the Danube Basin or CLP has not yet been made. Meanwhile, detailed stratigraphic correlations have been achieved between loess sections in southeastern Europe and China (Marković et al., 2015; Necula et al., 2015; Sümegi et al., 2018).

The contradictory position of the MBB in different stratigraphic units within loess sequences, even within nearby areas of Ukraine, inevitably complicates regional correlations. According to detailed magnetostratigraphic studies of more than 60 loess-palaeosol sections in Ukraine and neighbouring territories (Tretyak et al., 1987, 1989; Tretyak and Vigilyanskaya, 1994; Vigilyanskaya and Tretyak, 2000, 2002; Vigilyanskaya, 2001), the MBB belongs within the lowermost part of the Shyrokyne soil unit (sh) ${ }^{1}$. In some sections the MBB was detected in the Berezan loess (br; Tretyak and Volok, 1976), Sula loess (sl; Tretyak, 1983) and upper part of the Martonosha soil (mr; Sirenko et al., 2008), and in western Ukraine it has been located in the Zahvizdya palaeosol S7 (which is comparable to the Martonosha unit; Nawrocki et al., 2002). In stratigraphic schemes proposed for the Ukrainian Quaternary, the MBB is placed in the Martonosha unit (MIS 17-19; Lindner et al., 2004, 2006; Matviishyna et al., 2010; Gozhik and Gerasimenko, 2011; Gozhyk, 2012). It is generally argued that the Shyrokyne interglacial occurred 0.85-1.2 Ma (Matviishyna et al., 2010) and corresponds to MIS 21-33 (Lindner et al., 2004, 2006), MIS 21-35 (Gozhyk, 2012) or MIS 21-37 (Matviishyna et al., 2010). The Pryazovya loess (pr) and upper part of the Shyrokyne soil, characterized by normal polarity, were correlated by Veklich (1987), Matviishyna et al. (2010), Gozhik and Gerasimenko (2011) with the Jaramillo subchron, while authors of focused palaeomagnetic studies (Tretyak et al., 1987; Tretyak and Vigilyanskaya, 1994) considered them to be part of the Brunhes chron. Only one correlation model has been proposed between stratigraphic schemes of the loess-palaeosol succession of Ukraine and the MIS scale in which the Shyrokyne unit was equated with MIS 17-19 (Bolikhovskaya and Molodkov, 2006); however, this concept did not gain general acceptance.

Revision of the chronostratigraphy of the longest loesspalaeosol archives in Ukraine based on updated magnetostratigraphic data, as well as substantiated MIS correlation, was thus necessary. In this paper, we summarize palaeomagnetic and palaeoclimatic results from the Roksolany and Vyazivok loess-palaeosol sequences, one of the best developed Pleistocene successions of the Ukrainian terrestrial stratigraphy.

\section{OVERVIEW OF STRATIGRAPHY AND MAGNETOSTRATIGRAPHY}

\author{
ROKSOLANY SECTION
}

The Roksolany (this is the correct spelling; in some papers known as Roxolany) section is located on the coast of the Dniester estuary west of Roksolany village (46 $11^{\circ} \mathrm{N}$; $\left.30^{\circ} 26^{\prime} \mathrm{E}\right)$, $40 \mathrm{~km}$ south of Odesa (Fig. 1). This section is one of the most representative exposures of Pleistocene loess in the Black Sea Lowland. The terrace deposits comprise the VII (Chepalyga, 1967) or VIII (Tsatskin et al., 1998) Dniester terrace alluvium which erosionally overlies the Pontic deposits (Gozhik et al., 2007). These units are covered by loess, loam and palaeosol succession almost $55 \mathrm{~m}$ thick. The significance of the Roksolany sequence for European loess research was noted by the Ukrainian-Polish field workshop held in 2013 (Bogutskyi and Tomenyuk, 2013), for which a collective monograph (Bogucki et al., 2013) was prepared.

The stratigraphy of the Roksolany section and the position of the MBB is a matter of debate. The succession was classified by P. Gozhik and colleagues (Gozhik, 1976; Guidebook, 1982; Gozhik et al., 1995, 2000, 2007; Bogucki et al., 2013; Łanczont et al., 2015; see left of Table 1) in accordance with domestic stratigraphic nomenclature (Veklich et al., 1967, 1984a, 1993; left-side of Table 2). The first palaeomagnetic studies (Tretyak, 1980, 1983; Tretyak et al., 1987, 1989; Tretyak and Vigilyanskaya, 1994) proposed that the entire Roksolany profile belongs to the Brunhes chron, despite many magnetozones of reversed polarity having been observed (Fig. 2). In the interpretation of Tretyak et al. (1987), Tretyak and Vigilyanskaya (1994), the MBB could not be determined in the section, since it was said to belong to the Shyrokyne unit and so would have to be outside the profile. However, Gozhik et al. (1995, 2000, 2007) suggested that the MBB at Roksolany should be located in the middle part of the Martonosha soil (Fig. 2).

In the 1990s, based on the combined results of investigations into this section (Tsatskin et al., 1998, 2001; Sartori, 2000; Gendler et al., 2006), a completely different pedo- and magnetostratigraphy was proposed, as well as correlation of the loess-palaeosol sequence with the MIS scale. Heller et al. (1996) and Tsatskin et al. (1998) placed the MBB at a depth of $34 \mathrm{~m}$ in the middle part of the section, in loess layer $L_{6}$, which corresponds to the Tyasmyn unit (ts), and MIS 6 according to the classification cited in Gozhik et al. $(1995,2000)$ and Bogucki et al. (2013). This is $12 \mathrm{~m}$ above the position of the MBB according to the previous interpretation (Fig. 2). This notion was the basis for constructing a new pedostratigraphic scheme for the western Black Sea region with its subsequent correlation with the oxygen isotope time scale (Tsatskin et al., 2001; see middle of Table 1).

The following palaeomagnetic interpretation of the Roksolany section after Dodonov et al. (2006) generally coincided with the results of Tsatskin et al. $(1998,2001)$ and Sartori $(2000)$, but with one difference: at the base of the loess-palaeosol sequence the Jaramillo subchron was identified.

Our initial palaeomagnetic studies of the Roksolany profile (Bakhmutov and Hlavatskyi, 2014; Bakhmutov et al., 2017;

\footnotetext{
${ }^{1}$ Hereafter the stratigraphic terminology is used in accordance with the nomenclature of the stratigraphic divisions of the Pleistocene (Veklich et al., 1967, 1984a) and the Stratigraphic Framework of the Quaternary deposits of Ukraine (Veklich et al., 1993; Gozhyk, 2012). In this system, warm stages/soil units are named by stratotype localities, and cold stages/loess units by the nearest rivers, lakes and seas. Each chronostratigraphic unit has its own index consisting of two letters.
} 


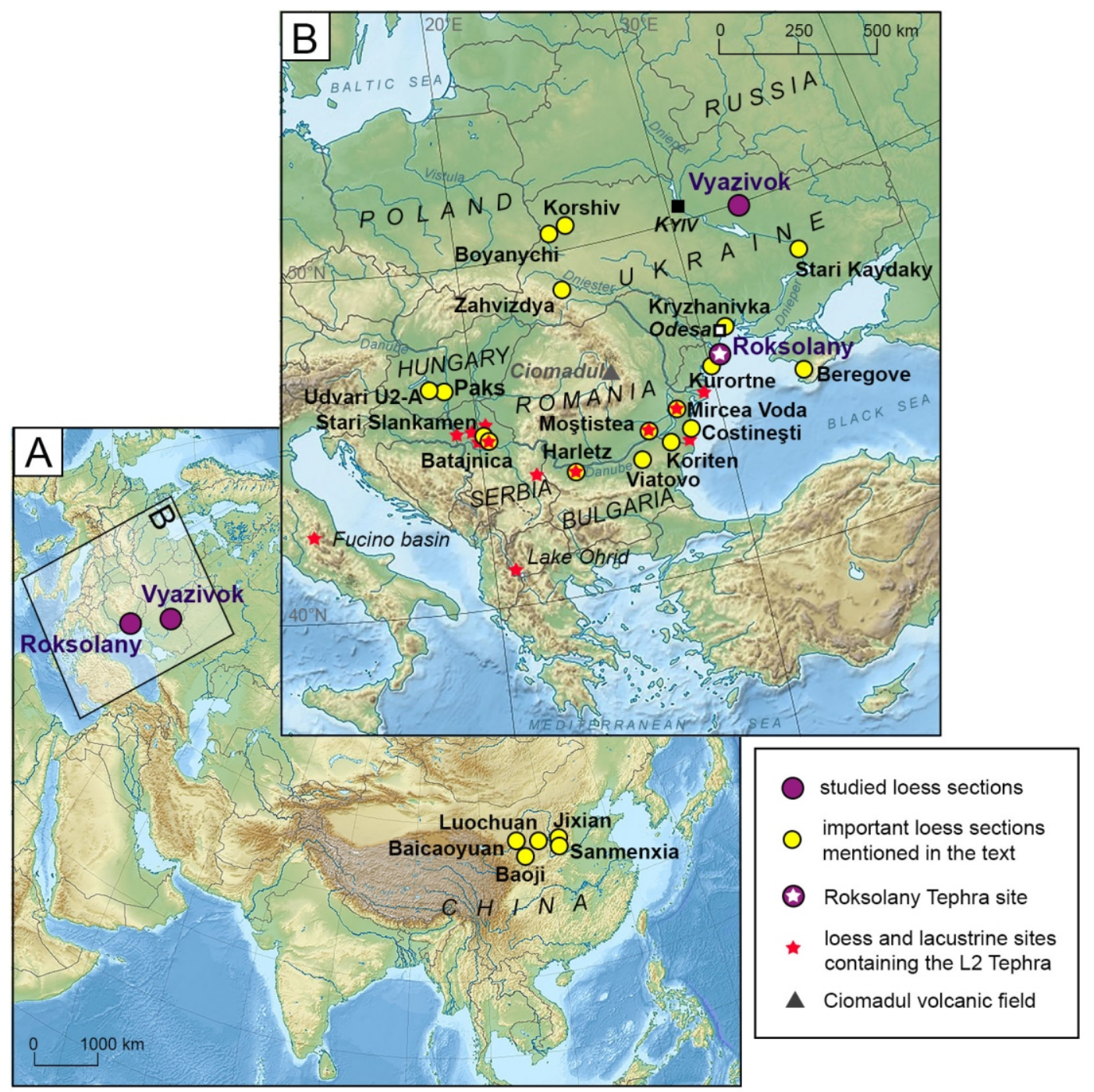

Fig. 1. Location maps indicating sections studied, selected most representative loess sequences and sites with identified L2 Tephra layer

A - Eurasia, B - Southeastern Europe. The geographical extent of the L2 Tephra according to Laag et al. (2018)

Hlavatskyi and Bakhmutov, 2019) revealed that the MBB is located at a depth of $46.6 \mathrm{~m}$ between two soils, which were classified by Gozhik et al. (2000, 2007) and Bogucki et al. (2013) as the Lubny (Ib, MIS 13-15) and Martonosha (MIS 17-19) units. A narrow zone of reversed polarity was also established at $42.0-42.5 \mathrm{~m}$ depth in the uppermost part of the Zavadivka soil (zv; Fig. 2).

We note here an incorrect citation of our previous study (Bakhmutov et al., 2017) in the recent paper of Bradák et al. (2019), in which the chronostratigraphy of the Roksolany section after Bogucki et al. (2013), including correlation between palaeosol $\mathrm{PK}_{4}$ and MIS 3, was mistakenly assigned entirely to us, although we cited all sources correctly, and noted previously that the modern stratigraphy of the Roksolany section most probably is incorrect (Hlavatskyi et al., 2016b; Hlavatskyi and Bakhmutov, 2018a, b). Therefore, to avoid further confusion, we need clarify critical chronostratigraphic issues in this study.

\section{VYAZIVOK SECTION}

The Vyazivok section is located in Vyazivok village $\left(49^{\circ} 57^{\prime} \mathrm{N} ; 32^{\circ} 57^{\prime} \mathrm{E}\right), \sim 8 \mathrm{~km}$ south of the city of Lubny, $180 \mathrm{~km}$ SE of Kyiv, on the western bank of the River Sula, a tributary of the Dnieper (Fig. 1). It represents one of the most complete Quaternary records in Ukraine and is the most complete section studied within the formerly glaciated Dnieper Lowland. This is a $59 \mathrm{~m}$ thick sequence of several well-developed palaeosols which alternate with thick loess units.

The Vyazivok section was originally described by Veklich et al. $(1967,1984 b)$ and studied later by many research groups (Matviishina et al., 2001; Rousseau et al., 2001; Vigilyanskaya, 2001; Gerasimenko, 2004, 2006; Gerasimenko and Matvijishyna, 2007). The sequence was the focus of the INQUA SEQS Conference held in 2001, where the loess stratigraphy, palaeopedology, palaeontological sequences, glacial phenomena and palaeomagnetic results were described in the excursion guide (Matviishina et al., 2001). There are no disputes about the stratigraphic subdivision of the section, but different authors correlate the stratigraphic units with the marine isotope record in different ways (see Table 2).

The first palaeomagnetic results of the uppermost part of the Vyazivok profile obtained by $O$. Tretyak and $Z$. Volok in the 1970s (in Veklich et al., 1984b) were interpreted from the base of the Sula loess - MIS 18 after Veklich (1995) or MIS 16 after Matviishyna et al. (2010). The interval studied demonstrated predominantly normal polarity, indicating deposition during the 
Chronostratigraphic models proposed for the Roksolany loess-palaeosol sequence

\begin{tabular}{|c|c|c|c|c|c|c|c|c|c|c|c|}
\hline \multicolumn{5}{|c|}{$\begin{array}{l}\text { Conventional stratigraphy, correlation with Chinese loess } \\
\text { stratigraphy and marine isotope stages (Gozhik, 1976; Gozhik et } \\
\text { al., 1995, 2000, 2007; Bogucki et al., 2013) }\end{array}$} & \multicolumn{2}{|c|}{$\begin{array}{l}\text { Pedostratigraphy and its } \\
\text { correlation with MIS } \\
\text { proposed by Tsatskin et } \\
\text { al. }(1998,2001) \\
\end{array}$} & \multicolumn{2}{|c|}{$\begin{array}{c}\text { Adapted } \\
\text { nomenclature } \\
\text { proposed by this } \\
\text { study } \\
\end{array}$} & \multirow{2}{*}{ 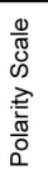 } & \multirow{2}{*}{ 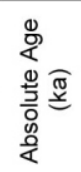 } & \multirow{2}{*}{ 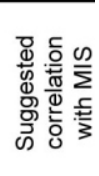 } \\
\hline & Palaeosol & & Loess & MIS & Palaeosol Loess & MIS & Palaeosol & Loess & & & \\
\hline \multirow[t]{10}{*}{ so } & Holocene soil (hl) & & & 1 & PK1 & 1 & R-SO & & & & 1 \\
\hline & & L1 & Prychornomorya(pč) & 2 & L1 & $2-4$ & & R-L1L1 & & & 2 \\
\hline & interstadial soil & & & & PK2 & 5 & R-L1S1 & & & & 3 \\
\hline & & L1 & Prychornomorya (pč) & 2 & L2 & 6 & & R-L1L2 & & & 4 \\
\hline & $\begin{array}{l}\text { Dofinivka } 1\left(\mathrm{df}_{1}\right) \\
\text { Dofinivka } 2\left(\mathrm{df}_{2}\right)\end{array}$ & & & & PK3 & $7-11$ & $\begin{array}{l}\text { R-S1S1 } \\
\text { R-S1S2 }\end{array}$ & & & & $\begin{array}{c}5 a-c \\
5 e\end{array}$ \\
\hline & & L1 & Bug (bg) & 2 & L3 & 12 & & R-L2 & & & 6 \\
\hline & Vytachiv (vt) & & & 3 & PK4 & $13-15$ & R-S2 & & & & 7 \\
\hline & & L1 & Uday (ud) & 4 & L4 & 16 & & R-L3 & 吕 & & 8 \\
\hline & interstadial soil & & & $5 a-d$ & PK5 & 17 & R-S3S1 & & 莖 & & $9 a$ \\
\hline & Pryluky (pl) & & & & PK6.1 & 19 & R-S3S2 & & ב & & $9 c$ \\
\hline \multirow{2}{*}{ S1 } & & & & $5 \mathrm{e}$ & PK6.2 & 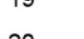 & R-S3S3 & & $\frac{\underline{c}}{\infty}$ & & $9 e$ \\
\hline & & L2 & Tyasmyn (ts) & 6 & L6 & 20 & & R-L4 & & & 10 \\
\hline \multirow{2}{*}{ S2 } & Kaydaky (kd) & & & 7 & PK7 & 21 & R-S4 & & & & 11 \\
\hline & & L3 & Dnipro (dn) & 8 & L7 & 22 & & R-L5 & & & 12 \\
\hline \multirow[t]{2}{*}{ S3 } & Potyagaylivka (pt) & & & 9 & incipient soil & 23 & R-S5 & & & & $13-15$ \\
\hline & & L4 & Oril (or) & 10 & & 24 & & R-L6 & & & 16 \\
\hline \multirow[t]{2}{*}{ S4 } & Zavadivka (zv) & & & 11 & PK8 & $25-27$ & R-S6 & & & 670 & 17 \\
\hline & & L5 & Tyligul (tl) & 12 & L8 & $28-30$ & & R-L7 & & & 18 \\
\hline S5 & Lubny (lb) & & & $13-15$ & PK9 & 31 & R-S7 & & & 780 & 19 \\
\hline \multirow[t]{2}{*}{ S7 } & Martonosha (mr) & & & $\begin{array}{l}17 \\
19\end{array}$ & PRY & & R-S8 & & 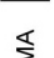 & & 21 \\
\hline & & L8 & Pryazovya (pr) & 20 & & & & R-L9L1 & $\frac{2}{t}$ & $850-$ & 22 \\
\hline \multirow[t]{3}{*}{ S8 } & Shyrokyne? (sh?) & & & 21 & & & R-L9S1 & & 5 & 900 & 23 \\
\hline & & & sandy & & & & & R-L9L2 & $\sum^{5}$ & & 24 \\
\hline & VII terr & allu & & & VIII terrace allu & vium & IX terrace al & Illuvium & & $<960^{*}$ & 25 \\
\hline
\end{tabular}

* Estimated age of alluvium deposits interpreted from index fossil mammals data (see text for further explanation). Other ages are supported by our magnetostratigraphic results

Chronostratigraphic models proposed for the Vyazivok loess-palaeosol sequence

\begin{tabular}{|c|c|c|c|c|c|c|c|c|c|c|c|}
\hline \multicolumn{3}{|c|}{$\begin{array}{l}\text { Stratigraphy (Veklich et al., 1967, 1984b; } \\
\text { Matviishina et al., 2001), and correlation with } \\
\text { marine isotope stages (Rousseau et al., } \\
\text { 2001; Gerasimenko, 2004, 2006) }\end{array}$} & \multicolumn{4}{|c|}{$\begin{array}{l}\text { Theoretical correlation of national } \\
\text { stratigraphy (Veklich et al., 1993) with } \\
\text { marine isotope stages (on the example of } \\
\text { the stratigraphy of Vyazivok) according to* }\end{array}$} & \multicolumn{2}{|c|}{$\begin{array}{l}\text { Adapted } \\
\text { nomenclature } \\
\text { proposed by this } \\
\text { study }\end{array}$} & \multirow{2}{*}{$\begin{array}{l}\frac{0}{\pi} \\
\text { D } \\
\frac{7}{2} \\
\frac{\pi}{0} \\
\frac{\pi}{0}\end{array}$} & \multirow{2}{*}{ 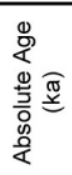 } & \multirow{2}{*}{ 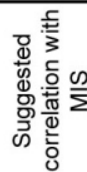 } \\
\hline Palaeosol & Loess & MIS & A & $B$ & C & $\mathrm{D}$ & Palaeosol & Loess & & & \\
\hline \multirow{2}{*}{ Holocene soil (hl) } & & 1 & 1 & 1 & 1 & 1 & V-SO & & & & 1 \\
\hline & Bug (bg) & 2 & $2-4$ & 2 & 2 & $2-4$ & & V-L1L1 & & & 2 \\
\hline \multirow{2}{*}{ Vytachiv (vt) } & & 3 & 5 & 3 & 3 & & V-L1S1 & & & & 3 \\
\hline & Uday (ud) & 4 & & 4 & 4 & & & V-L1L2 & & & 4 \\
\hline \multirow[t]{2}{*}{ Pryluky (pl) } & & $5 a-c$ & 5 & 5 & $5 a-c$ & 5 & V-S1S1 & & & & $5 a-c$ \\
\hline & Tyasmyn (ts) & $5 d$ & 6 & 6 & $5 d$ & & & V-S1L1 & & & $5 d$ \\
\hline \multirow{2}{*}{ Kaydaky (kd) } & & $5 e$ & 7 & 7 & $5 e$ & 5 & V-S1S2 & & & & $5 e$ \\
\hline & Dnipro (dn) & 6 & 8 & 8 & 6 & 6 & & V-L2 & 出 & & 6 \\
\hline \multirow[t]{2}{*}{ Potyagaylivka (pt) } & & & 9 & 9 & 7 & 7 & V-S2 & & 岌 & & 7 \\
\hline & Oril (or) & & 10 & 10 & 8 & 8 & & V-L3 & ב & & 8 \\
\hline \multirow{3}{*}{$\begin{array}{l}\text { Zavadivka } 3\left(\mathrm{Zv}_{3}\right) \\
\text { Zavadivka } 1\left(\mathrm{zv}_{1}\right)\end{array}$} & & & & & 9 & & V-S3 & & $\frac{\vec{r}}{\infty}$ & & 9 \\
\hline & & & 11 & 11 & 11 & 9 & V-S4 & & & & 11 \\
\hline & Tyligul (tl) & & 12 & 12 & 12 & 10 & & V-L5 & & 430 & 12 \\
\hline \multirow[t]{2}{*}{ Lubny (lb) } & & & $13-17$ & $13-15$ & $13-15$ & 11 & V-S5 & & & & $13-15$ \\
\hline & Sula (sl) & & 18 & 16 & 16 & 12 & & V-L6 & & & 16 \\
\hline \multirow[t]{2}{*}{ Martonosha (mr) } & & & $19-23$ & $17-19$ & $17-19$ & $13 ?-15$ & V-s6 & & & & 17 \\
\hline & Pryazovya (pr) & & 24 & 20 & 20 & 16 & & V-L7 & & & 18 \\
\hline Shyrokyne $3\left(\mathrm{sh}_{3}\right)$ & & & $25-\ldots$ & $21-23$ & $21-25$ & 17 & V-S7S1 & & & \multirow{3}{*}{780} & $19 a$ \\
\hline \multirow[t]{2}{*}{ Shyrokyne $1\left(\mathrm{sh}_{1}\right)$} & & & & $31-33$ & $31-37$ & 19 & V-S7S2 & \multirow{3}{*}{ V-L8 } & - & & $19 c$ \\
\hline & Illichivsk (il) & & & $34-36$ & $38-40$ & 20 & & & & & 20 \\
\hline Kryzhanivka (kr) & & & & $37-57$ & $41-\ldots$ & 21 & V-S8 & & $\sum$ & & 21 \\
\hline
\end{tabular}

* A - Veklich,1995; B - Gozhik et al., 2000; Lindner et al., 2004, 2006; C - Matviishyna et al., 2010; D - Bolikhovskaya and Molodkov, 2006

** $\mathbf{M}$ - Matuyama chron

Ages are distributed in accordance with our magnetostratigraphic data 


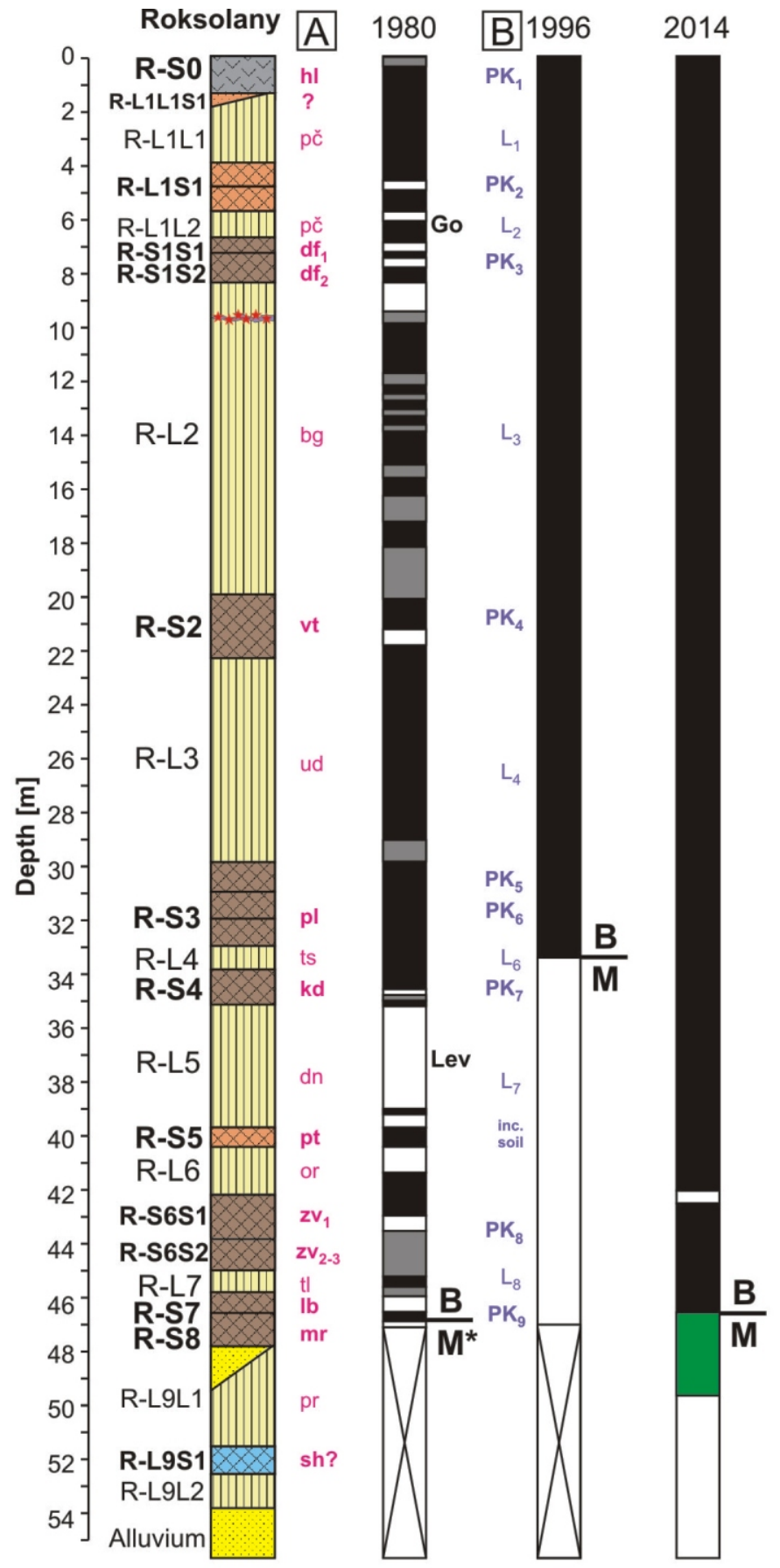

\section{Lithology}
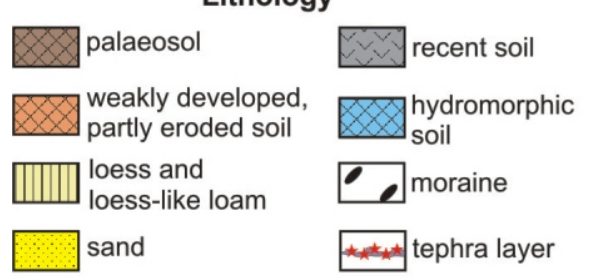

\section{Chron}

$B=$ Brunhes

$\mathrm{M}=$ Matuyama

Magnetic event

Go $=$ Gothenburg

$\mathrm{La}=$ Laschamp

Blk = Blake

Lev $=$ Levantine

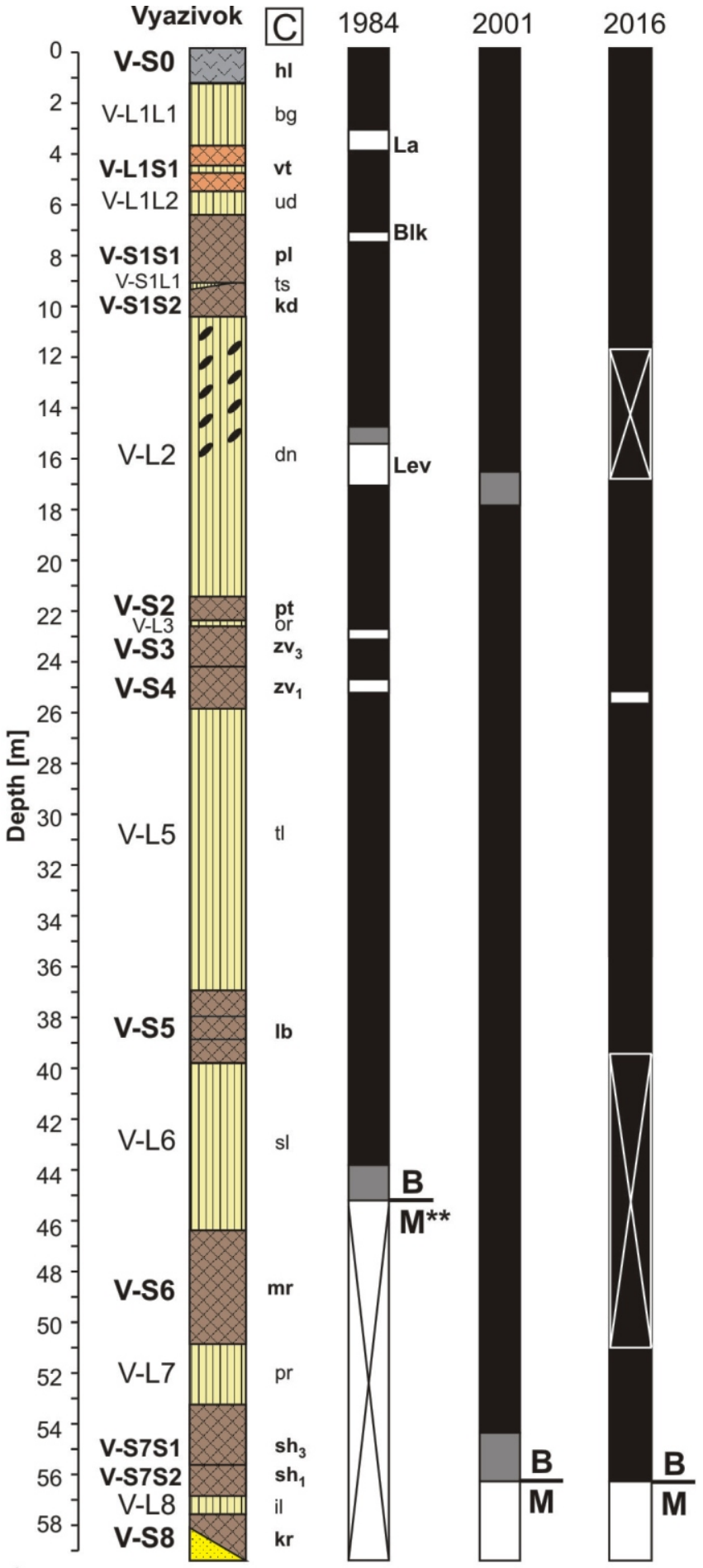

Polarity

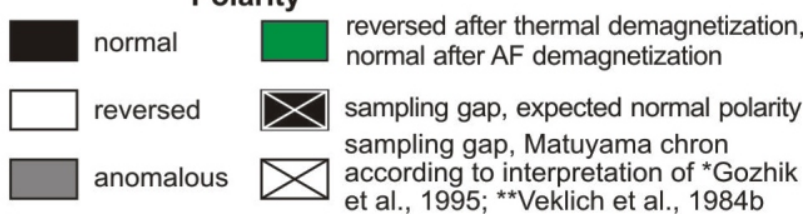

Fig. 2. Development of the geomagnetic polarity scales of the Roksolany and Vyazivok section

The initial data from the Roksolany section (Tretyak, 1980) was abandoned by Heller et al. (1996) and revised recently by Bakhmutov and Hlavatskyi (2014). Expected position of the MBB in the Vyazivok section (Veklich et al., 1984b) was refined by Vigilyanskaya (2001) and supported later by Hlavatskyi et al. (2016b). To the left of each lithological column the stratigraphic nomenclature proposed by this study is shown (see text for further explanation). A - stratigraphic subdivision from Gozhik et al. (1995, 2000, 2007) and Bogucki et al. (2013); B designation system proposed by Tsatskin et al. (1998); C - stratigraphic subdivision from Veklich et al. (1967) and Matviishina et al. (2001). For detailed litho- and pedostratigraphy see Figure 3 
Brunhes chron (Fig. 2). One last sample from the lowermost level of the Sula loess unit revealed the anomalous polarity and the position of the MBB was announced eventually at the top of the Martonosha palaeosol (Veklich et al., 1984b; see fig. 8 in Matviishina et al., 2001, and also Fig. 2 in this study). The suggestion that the MBB belongs to the Martonosha unit in the Roksolany and Vyazivok sections served as a basis for pan-European stratigraphic correlations (Chlebowski et al., 2003; Lindner et al., 2004, 2006) and in part for subsequent palaeoclimatic reconstructions (Matviishyna et al., 2010; Gozhik and Gerasimenko, 2011).

Later, the whole sequence was studied by Vigilyanskaya (2001; composite palaeomagnetic section in Matviishina et al. (2001: fig. 9; see also Fig. 2 in this study). The position of the MBB in the Martonosha unit was not confirmed, but it was placed below in the Shyrokyne palaeosol.

New palaeomagnetic results from the Vyazivok section were provided recently in Hlavatskyi et al. (2016b). The MBB was detected at a depth of $56.2 \mathrm{~m}$ within the lower Shyrokyne palaeosol $\mathrm{sh}_{1}$ (according to the stratigraphic subdivision of Matviishina et al., 2001), which is close to the previous palaeomagnetic interpretation of Vigilyanskaya (2001).

In Figure 3, we summarize morphological, pedological and palaeoenvironmental data from the loess-palaeosol successions investigated. The data were modified according to our current knowledge from Tsatskin et al. (1998), Gozhik et al. (2007), Bogucki et al. (2013) for the Roksolany section, and from Matviishina et al. (2001) and Rousseau et al. (2001) for the Vyazivok section.

\section{SAMPLING AND METHODS}

A representative collection of samples from the Roksolany section (127 oriented rectangular blocks and 203 mini-cores) was collected in 2012 and 2013 from 9 overlapping exposures (Fig. 4A, B). The magnetization of the rocks is too small to affect the compass needle, and the cores and blocks were oriented with a magnetic compass. We paid extra attention to the more problematic levels below $30 \mathrm{~m}$ depth, taking extra samples, with a sampling density of about every $2-15 \mathrm{~cm}$. For palaeomagnetic measurements standard cylinders $(2.2 \mathrm{~cm}$ in length and $2.5 \mathrm{~cm}$ in diameter) and cubes $(2.0 \mathrm{~cm}$ side) were cut (2-4 specimens from each sample). In total, 802 oriented specimens from the depth interval $0.50-54.59 \mathrm{~m}$ were investigated.

In the Vyazivok section, 214 samples (all oriented rectangular blocks) were collected in 2014, 2015 and 2019 from 6 continuous exposures (Fig. 5A, B). The Sula and Martonosha units have been affected by slope processes which prevented further sampling. To obtain a high-resolution MS record, 749 non-oriented specimens from the depth interval $0.72-59.00 \mathrm{~m}$ were measured (2019).

An initial magnetostratigraphic interpretation of the Roksolany section was provided by Bakhmutov and Hlavatskyi (2014), Bakhmutov et al. (2017) and Hlavatskyi and Bakhmutov (2019). In this study, we have adopted the palaeomagnetic interpretation of Bakhmutov et al. (2017), Hlavatskyi and Bakhmutov (2019) for 115 specimens below $35 \mathrm{~m}$ depth, and add new results for 82 specimens from the lowermost part of the profile. In particular, we increased the sampling density within the 40.5-42.5 m depth interval in order to confirm or refute the zone of reversed polarity.

Preliminary results of the palaeomagnetic studies of the Vyazivok section were given in Hlavatskyi et al. (2016b). In order to refine the position of the MBB, we now focus on the lowermost part of the profile. In particular, duplicate specimens from two neighbouring exposures (V5 and V6) representing the Pryazovya, Shyrokyne, Illichivsk (il) and Kryzhanivka (kr) units were treated. Besides 54 specimens from the units listed above, already investigated by Hlavatskyi et al. (2016b), we add new data from 48 demagnetized specimens below $51 \mathrm{~m}$ depth.

The palaeomagnetic measurements were carried out in the laboratory of the Institute of Geophysics of the National Academy of Sciences of Ukraine (Kyiv). The directions of the more stable remanent magnetization component were isolated by both stepwise thermal and alternating field (AF) demagnetization. Demagnetization of specimens and measurements of remanent magnetization were carried out inside a magnetically shielded space (a low-field cage MMLFC) to minimize the acquisition of the present-day viscous magnetization.

Specimens were thermally demagnetized using a MMTD 80 furnace at up to $270-350^{\circ} \mathrm{C}$ (at higher temperatures the samples crumbled). The residual field in the furnace was less than $10 \mathrm{nT}$. After each heating step, bulk susceptibility $(\kappa)$ at room temperature was measured with a MFK1-B Kappabridge to monitor possible mineralogical changes. Duplicate specimens were subjected to AF demagnetization with steps of 5-20 mT up to $100 \mathrm{mT}$ using a $L D A-3 A$ demagnetizer. The natural remanent magnetization (NRM) of specimens was measured by a JR- 6 spinner magnetometer. Duplicate specimens were measured in the palaeomagnetic laboratory of the Institute of Geophysics of the Polish Academy of Sciences (Warsaw) using a $2 G$ SQUID DC magnetometer accompanied by an AF demagnetizer.

Visual inspection during sampling in the Roksolany section had shown the presence of molehills in some units. In order to avoid errors due to mechanical disturbances, the anisotropy of the magnetic susceptibility was analysed. Anomalous devia-

Fig. 3. Revised lithostratigraphic subdivision and correlation of magnetic susceptibility $(\chi)$ of Roksolany and Vyazivok loess-palaeosol sequences with the marine oxygen isotope record

Summarized lithological and pedological characteristics of the Roksolany section (data from Tsatskin et al., 1998; Gozhik et al., 2007; Bogucki et al., 2013) and Vyazivok section (Matviishina et al., 2001; Rousseau et al., 2001) are modified. Stratigraphies: to the left of each lithological column - our provisional designation system; to the right: $\mathbf{A}$ - stratigraphic subdivision proposed by this study; $\mathbf{B}$ - stratigraphy proposed by Gozhik et al. (1995, 2000, 2007) and Bogucki et al. (2013); C - subdivision after Matviishina et al. (2001). Direct stratigraphic correlation of Bug loess in Roksolany and Vyazivok sections after Chlebowski et al. (2003) is shown by violet dashed line, and proposed correlation of the L2 (Dnipro) loess by yellow shading. Theoretical correlation between soil units in the stratigraphic subdivision of Gozhik et al. (1995, 2000, 2007), Bogucki et al. (2013; Roksolany section), and Matviishina et al. (2001; Vyazivok section) is made in accordance with the labelling system of the Stratigraphic Framework of the Quaternary deposits of Ukraine (Veklich et al., 1993; Gozhyk, 2012). Alternative correlations by magnetic susceptibility variations, the position of the MBB, palaeoenvironmental and palaeopedological features are proposed by this study. The inferred chronology, related to marine isotope stages (MIS), has resulted from the magnetic susceptibility stratigraphy. Marine oxygen isotope $\left(\delta^{18} \mathrm{O}\right.$ ) record is from ODP site 677 (Shackleton et al., 1990). Lettered marine isotope substages interpreted from Railsback et al. (2015). The $\delta^{18} \mathrm{O}$ values are inverted in order to show variation similar to the $\chi$-curve. The ODP 677 record provides detailed information concerning global ice volume with larger values representing more ice 


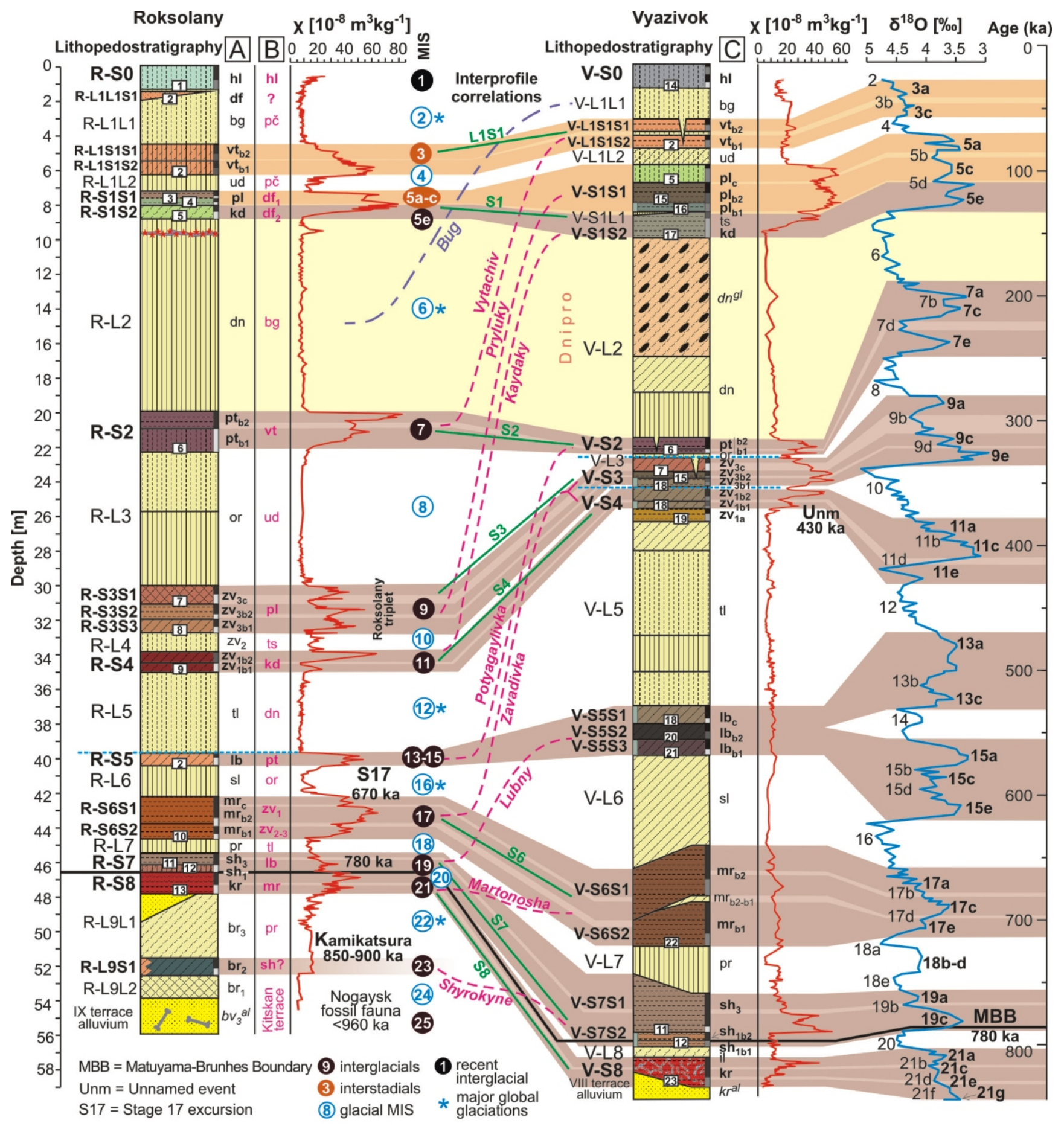

Lithology, fossils

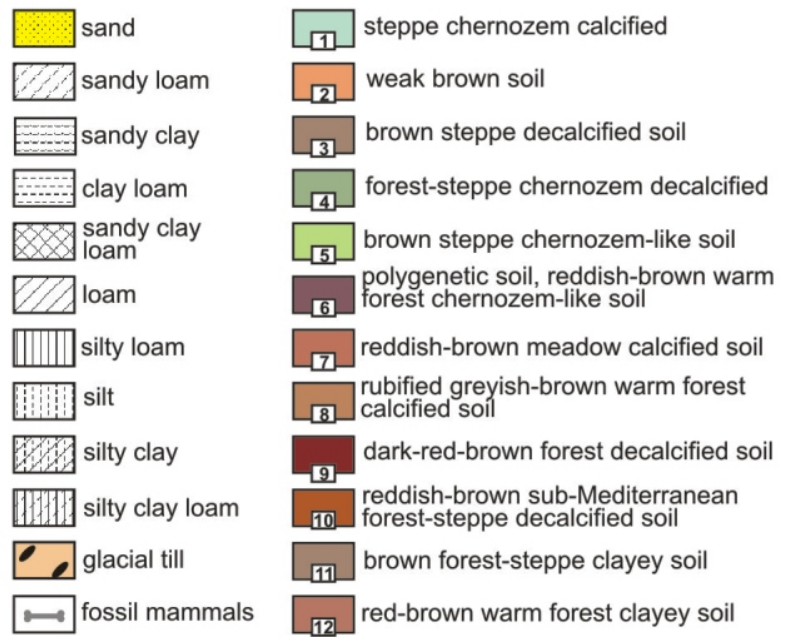

\section{Soil horizon}

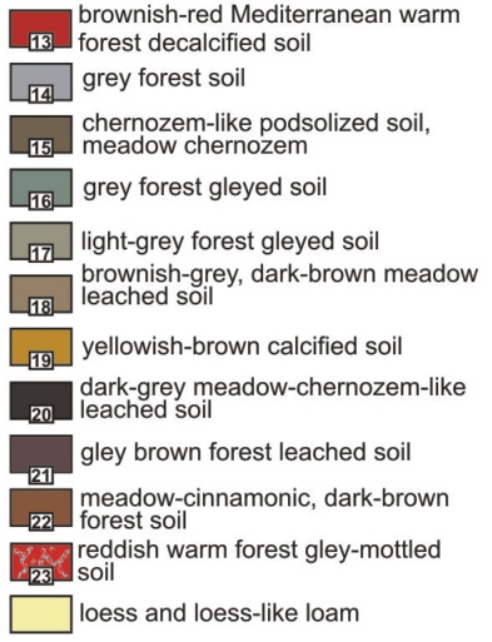

$\square \mathrm{A} \square \mathrm{A} 1 \square$ АB

$\square$ B $\square$ Btf $\square$ Bca

ydromorphic features:

replacement with hydromorphic soil

tephra layer

$\mathrm{V}$ ice wedges

erosional incision

\section{Correlations}

direct and theoretical stratigraphic correlations magnetostratigraphic correlation

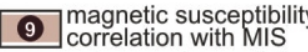
palaeoenviromental and palaeopedological correlation markers 


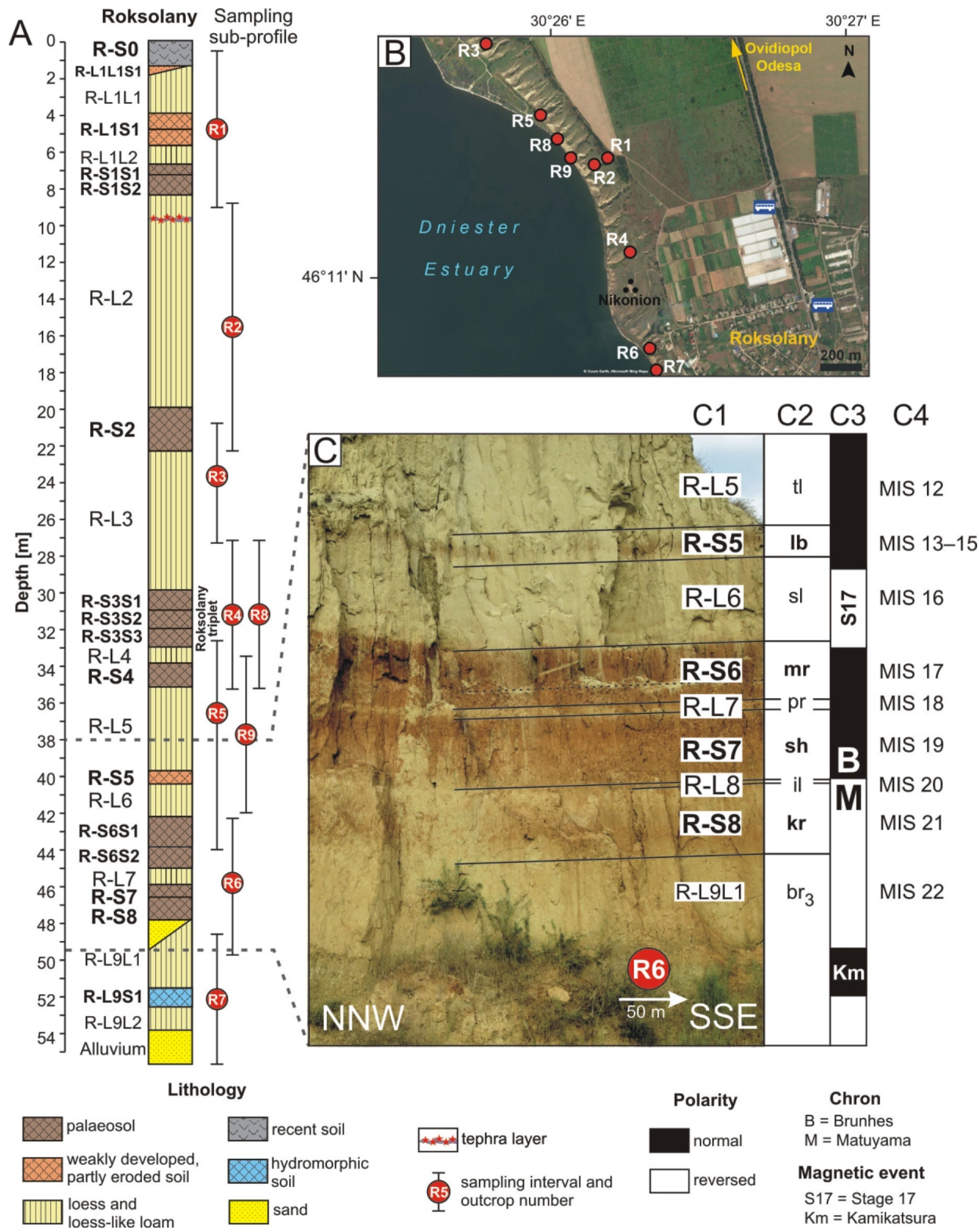

Fig. 4. Location of samples taken from the Roksolany section

A - sampling intervals of numbered exposures; $\mathbf{B}$ - map showing location of exposures studied; C - field photograph of lowermost units of the Roksolany section. C1 (Chinese nomenclature) and C2 (designation system in Veklich et al., 1993) - stratigraphic subdivision proposed by this study; C3 - magnetic polarity zonation from this study; C4 - suggested correlation with marine isotope stages (see text for further explanation) 


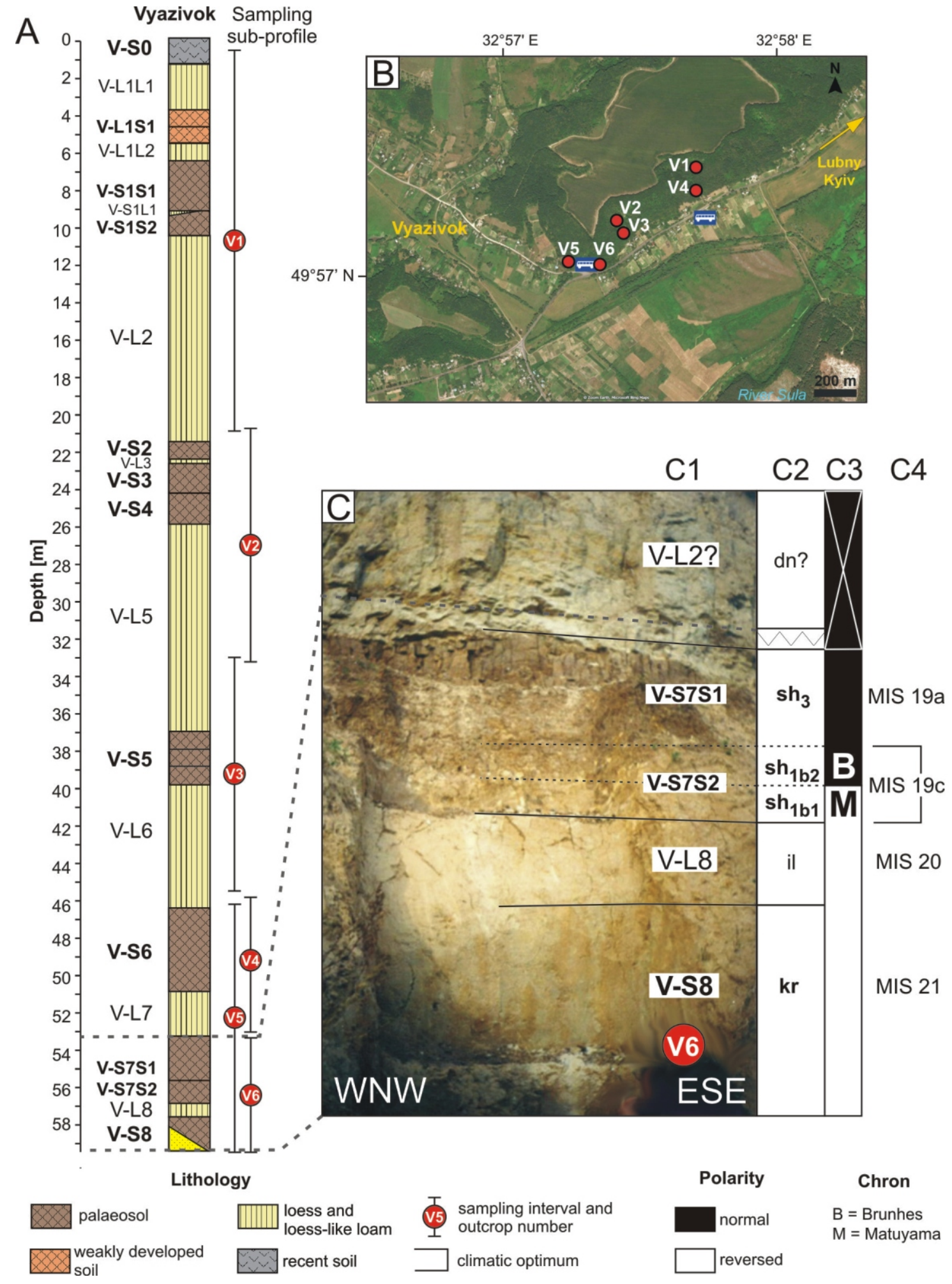

Fig. 5. Location of samples taken from the Vyazivok section

A - sampling intervals of numbered exposures; B - map showing location of exposures studied; C - field photograph of lowermost units of the exposure studied (photo courtesy of N. Gerasimenko). C1 - provisional stratigraphic nomenclature proposed by this study; C2 - stratigraphic subdivision according to Matviishina et al. (2001); C3 - lithostratigraphic position of the Matuyama-Brunhes boundary (our data); C4 - suggested correlation with marine isotope stages (see text for further explanation) 
tions from typical sedimentary structure $\left(\mathrm{K}_{\min }\right.$ axes should be normal relative to the sedimentary plane) and doubtful palaeomagnetic results were observed in 59 specimens, which were excluded from further interpretation (see Appendix $1^{*}$ ).

Demagnetization results were processed by multicomponent analysis of the demagnetization path (Kirschvink, 1980) using Remasoft 3.0 software (Chadima and Hrouda, 2006). Magnetostratigraphic columns were built with MPS software (Man, 2008), which allows more accurate identification of zones of normal and reversed polarity. Measurements of mass-specific susceptibility $(\chi)$ and anisotropy of magnetic susceptibility were carried out using a MFK1-B Kappabridge. The data were processed using Anisoft 4.2 software.

Age-depth models were constructed by a linear interpolation method using age tie points of MIS on the ODP stack's timescale (Lisiecki and Raymo, 2005) for corresponding loess and palaeosol units in the Roksolany section as a data set. Boundaries between lithostratigraphic units were identified both by field data and by MS variations. We calculated sedimentation rates $(\mathrm{SR}=\mathrm{cm} / \mathrm{ky})$ as a function of depth to compare values for the same lithostratigraphic units for our chronostratigraphic model and previous schemes. From the Vyazivok section no sedimentation rates were calculated because of an obvious erosional hiatus of the potentially thick Oril (or) and Middle Zavadivka $\left(\mathrm{zv}_{2}\right)$ loess units.

In order to avoid incorrect stratigraphic correlation resulted from conflicting stratigraphic schemes, we use a simplified provisional nomenclature adapted from the Chinese loess labelling system (Liu, 1985; Kukla, 1987), adding a prefix to indicate the section studied (Marković et al., 2003, cited in Marković et al., 2015; Buggle et al., 2008; see right side of Tables 1 and 2). Names were derived from the first letter of the name of the Roksolany section $\mathbf{R}$, and the Vyazivok section $\mathbf{V}$ with the designation $\mathbf{S}$ corresponding to palaeosols, and $\mathbf{L}$ to loess units (R-S0, R-L1, R-S1...; V-S0, V-L1, V-S1 etc.). In this system, loess and palaeosols appear with increasing numbers corresponding to older ages. Embryonic, weakly developed soils (or thin loess layers), intercalated in the main loess (palaeosol) units, were marked with the designation $\mathbf{L}(\mathbf{S})$ corresponding to loess (soil) unit followed with the designation $\mathbf{S}(\mathbf{L})$ indicating soil (loess) subunit (e.g., V-L1S1; V-S1L1).

The Chinese nomenclature is widely accepted in loess studies of Bulgarian (Jordanova and Petersen, 1999), Romanian (Panaiotu et al., 2001), Serbian (Marković et al., 2003, cited in Marković et al., 2015) and Hungarian stratigraphy (Sümegi et al., 2011, cited in Sümegi et al., 2018). Nevertheless, an analogous labelling system has also been applied to Ukrainian loess, e.g. in studies of the Zahvizdya (Nawrocki et al., 2002), Stari Kaydaky (Buggle et al., 2008, 2009) and Roksolany (Bogucki et al., 2013; Łanczont et al., 2015) sections.

\section{RESULTS AND INTERPRETATION}

\section{MAGNETIC SUSCEPTIBILITY}

In the Roksolany section, MS shows the expected large difference between the palaeosols and loess layers (left-side of Fig. 3). Relatively weak susceptibility values in loess units show a small fluctuation $\left(5-10 \times 10^{-8} \mathrm{~m}^{3} \mathrm{~kg}^{-1}\right)$, while these values in soils are much higher (up to $82 \times 10^{-8} \mathrm{~m}^{3} \mathrm{~kg}^{-1}$ in the upper part of the R-S2 pedocomplex). The MS pattern in most of the soil units reveals 2-3 peaks. The MS curve of the R-S6 palaeosol has a specific tiered structure of three "cascades".

For the Vyazivok section, the MS record also follows generally the lithology (right-side of Fig. 3), being enhanced in the palaeosols compared to the loess. The strongest susceptibility enhancement can be observed in the V-S1 $\left(60 \times 10^{-8} \mathrm{~m}^{3} \mathrm{~kg}^{-1}\right)$, $\mathrm{V}-\mathrm{S} 3, \mathrm{~V}-\mathrm{S} 4$ and middle part of the V-S7 soil units (maximum $50 \times 10^{-8} \mathrm{~m}^{3} \mathrm{~kg}^{-1}$ each), whereas very low MS values are characteristic of the V-S5 pedocomplex with hydromorphic features $\left(10 \times 10^{-8} \mathrm{~m}^{3} \mathrm{~kg}^{-1}\right)$. Weak MS values $\left(10-20 \times 10^{-8} \mathrm{~m}^{3} \mathrm{~kg}^{-1}\right)$ are observed also in the well-developed V-S6 pedocomplex. The background MS values of the loess layers fluctuate around $10 \times 10^{-8} \mathrm{~m}^{3} \mathrm{~kg}^{-1}$. Interestingly, the MS curve in most of soil units has the form of a fork with sharp prongs. The MS record in V-S2 shows double peaks, while in V-S3, V-S4 and V-S7 there are three peaks. Further distinctive peak structures can be observed for the V-S1 pedocomplex, in which the lowermost subunit V-S1S2 has relatively lower MS enhancement and is clearly offset against the rest of the pedocomplex by a thin loess layer with low MS values.

The background MS of the Dniester and Dnieper loess sections is in the range of $5 \times 10^{-8}$ to $10 \times 10^{-8} \mathrm{~m}^{3} \mathrm{~kg}^{-1}$ (Buggle et al., 2009; this study), which is $2-5$ times lower compared to that in the Danube sequences $\left(15-25 \times 10^{-8} \mathrm{~m}^{3} \mathrm{~kg}^{-1}\right.$; Marković et al., 2012, 2015), and 4-10 times lower than on the CLP $\left(40-50 \times 10^{-8} \mathrm{~m}^{3} \mathrm{~kg}^{-1}\right.$; Kukla et al., 1988; Sun et al., 2006, cited in Liu et al., 2015). This difference indicates a contribution from an alternative dust source, most likely the area of glaciofluvial deposits in northern Ukraine (Buggle et al., 2009; Bakhmutov et al., 2017)

The MS measured at Chinese, Bulgarian, Romanian and Serbian loess profiles shows a strong contrast between loess and palaeosol horizons (Kukla et al., 1988; Jordanova and Petersen, 1999; Marković et al., 2012, 2015; Necula et al., 2015). The cyclicity of alternating high and low MS values between palaeosols and loess units reflects different degrees of pedogenesis between glacial and interglacial periods as a result of the formation of small superparamagnetic particles yielding higher values for palaeosols compared to loess (Heller and Liu, 1982, 1984; Kukla et al., 1988; Zhou et al., 1990; Maher, 1998). The MS behaviour of southern Ukrainian loess (including the sequence at Roksolany) is similar to that observed in Chinese loess deposits (Bakhmutov et al., 2017). However, MS in northern Ukrainian (in particular, Vyazivok, Boyanychi, Korshiv) and some Hungarian (Udvari-U2) loess-palaeosol sections often does not depend on lithology: the soils and loess have both high and low MS values (Nawrocki et al., 1999; Hlavatskyi et al., 2016a, b; Sümegi et al., 2018). These sequences cannot be classified either as Alaskan type or as Chinese type of magnetic properties of subaerial sediments (Bakhmutov et al., 2017). The occurrence of atypical MS patterns in soils is caused in most cases by a humidity-induced transformation of ferromagnetic minerals (Sümegi et al., 2018), which is clearly also evident for the V-S5 pedocomplex at Vyazivok.

\section{MAGNETOSTRATIGRAPHY OF THE ROKSOLANY SECTION}

Here we discuss the results from 197 specimens from the lowermost part of the Roksolany profile below $35 \mathrm{~m}$ depth.

The data from thermal demagnetization seem more informative: there is less scatter between demagnetization steps, 

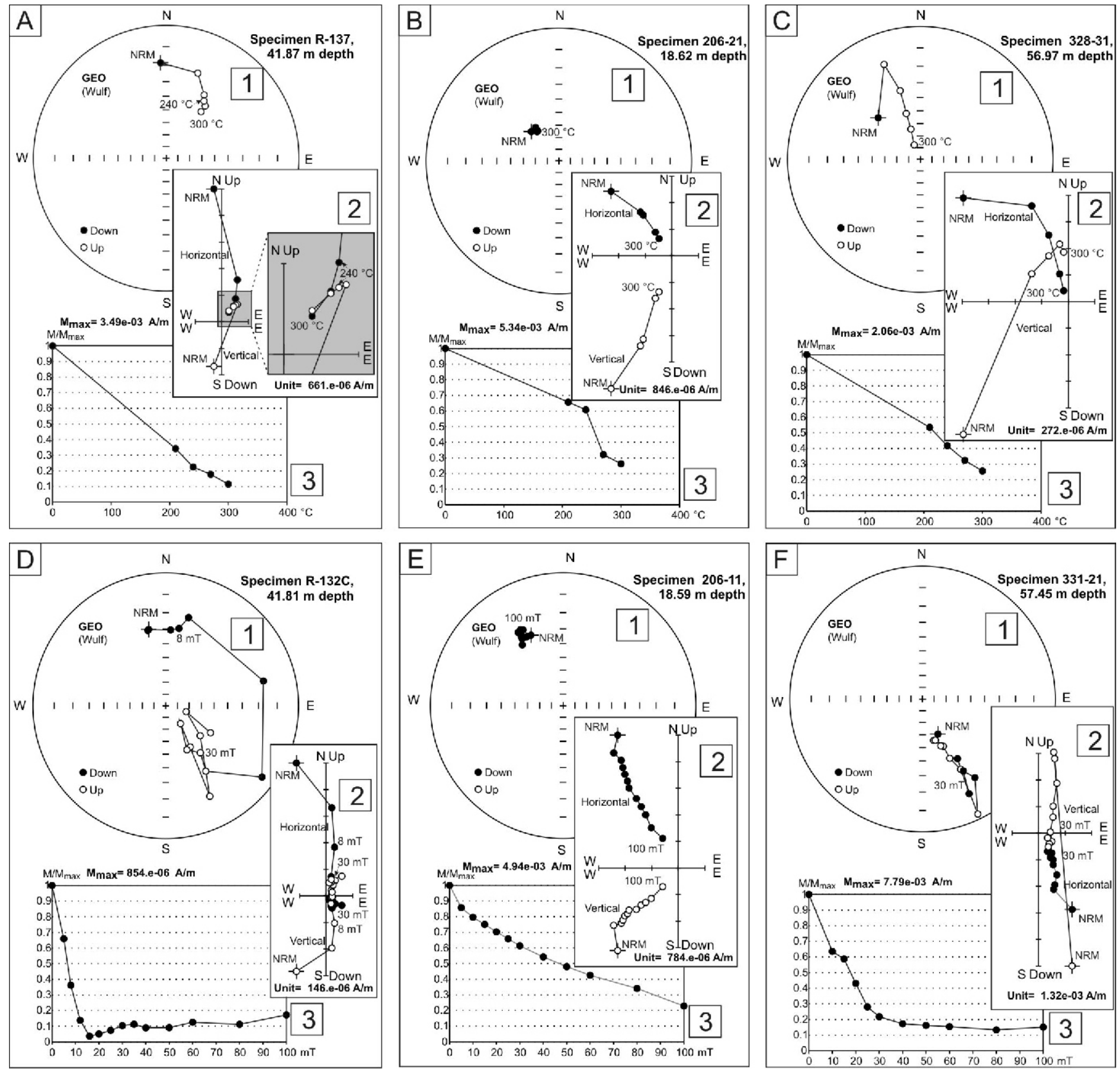

Fig. 6. Examples of stepwise thermal (A, B, C) and alternating field (D, E, F) demagnetization of loess specimens from the R-L6 unit (A, D) in the Roksolany section; loess specimens from the V-L2 unit (B, E), and palaeosol specimens from the V-S7 unit $(C, F)$ in the Vyazivok section

1 - stereographic projections of demagnetization directions (full and open circles represent projections in the lower and upper hemispheres, respectively); 2 - orthogonal demagnetization paths (Zijderveld diagrams) on horizontal and vertical planes; 3 - NRM intensity decay curves of demagnetization $\left(\mathrm{M} / \mathrm{M}_{\max }\right)$

and conformity with the results of neighbouring specimens, while frequent coincidence of thermal and AF demagnetization results were observed. Since most of the specimens were fragile, they could not be heated to temperatures $>300^{\circ} \mathrm{C}$ and we were limited to a few demagnetization steps at temperatures $180,210,240,270^{\circ} \mathrm{C}$ and higher if a specimen did not break.

Multicomponent analysis of demagnetization paths revealed that the NRM was composed of two components. The low stability component was erased in the temperature up to $180-210^{\circ} \mathrm{C}$ (sometimes $240^{\circ} \mathrm{C}$, see example in Fig. $6 \mathrm{~A}$ ) or by AF up to 10-20 mT (sometimes $30 \mathrm{mT}$, Fig. 6D). The more sta- ble (further - characteristic, ChRM) component in many palaeosol specimens was $<5 \%$ of the initial NRM while in loess it was $\sim 10-20 \%$. In some specimens the ChRM component was not displayed or could not be distinguished by component analysis because low values of remanent intensity were observed even using a SQUID magnetometer.

The final demagnetization results of 134 specimens, treated by temperature, and 63 specimens, demagnetized by AF from the lowermost part of the Roksolany section (35.4-54.59 m depth) with the composite magnetostratigraphic column, are given in Figure 7 . With the intermediate directions 


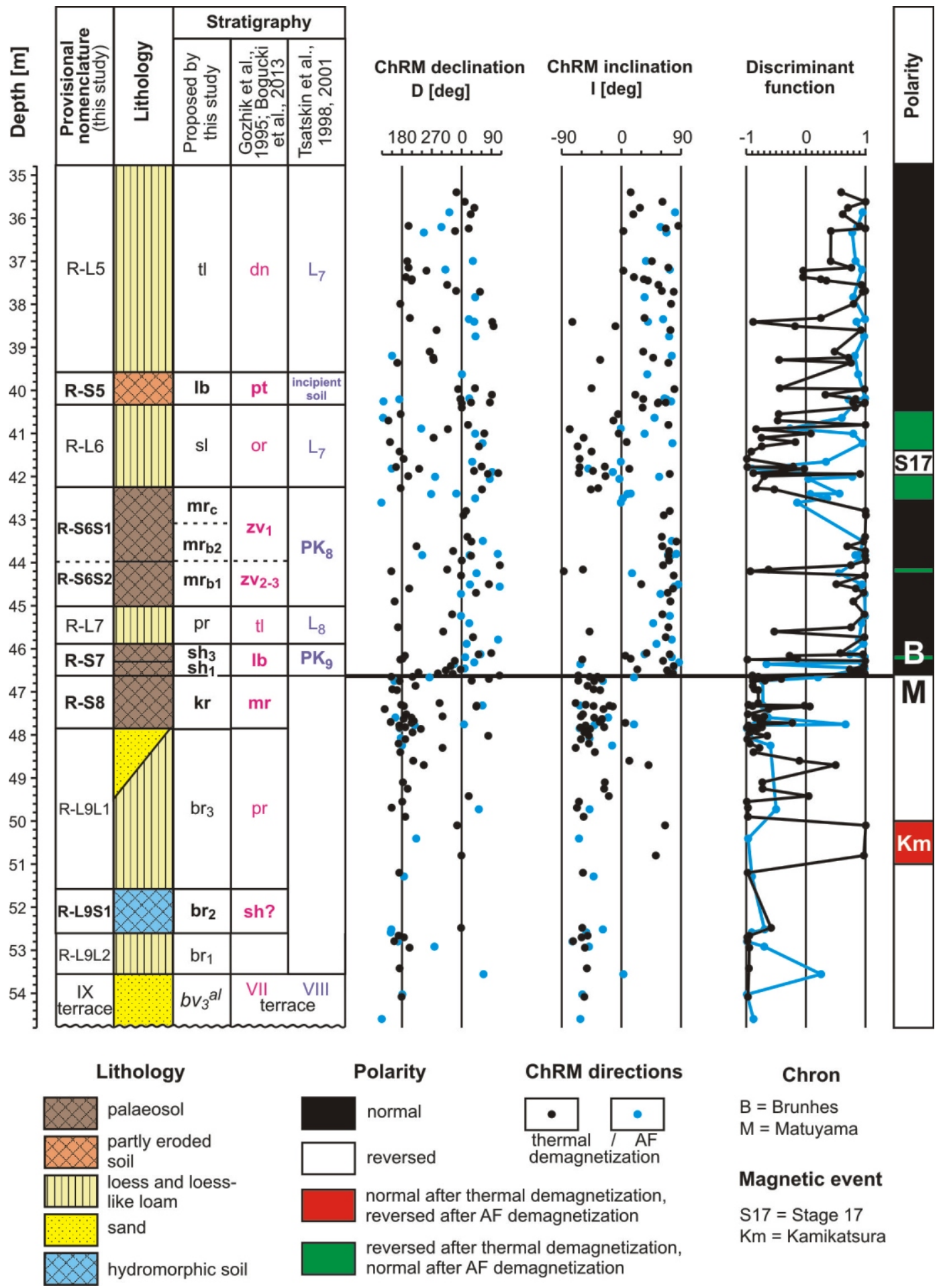

Fig. 7. Results of palaeomagnetic study of the lowermost part of the Roksolany section

From the left - simplified lithostratigraphy, the directions of the ChRM components (expressed by declination $D^{\circ}$ and inclination $I^{\circ}$ ), the discriminant function of these directions (Man, 2008) as a function of depth, and magnetostratigraphic chart 
Table 3

The position of geomagnetic excursions recorded in the sections studied

\begin{tabular}{cccl}
\hline $\begin{array}{c}\text { International } \\
\begin{array}{c}\text { Geomagnetic } \\
\text { Polarity } \\
\text { Scale }\end{array}\end{array}$ & $\begin{array}{c}\text { Magnetic } \\
\text { event }\end{array}$ & $\begin{array}{c}\text { Age } \\
(\mathrm{ka})\end{array}$ & \multicolumn{1}{c}{ Location (depth, m) } \\
\hline BRUNHES & Unnamed & 430 & Vyazivok (25.5) \\
& Stage 17 & 670 & Roksolany (40.5-42.5) \\
& MBB & 780 & Roksolany (46.6); \\
& Kamikatsura & $850-$ & Roksolany (50-50.8) \\
\hline MATUYAMA & 900 & Roks (56.2) \\
\hline
\end{tabular}

omitted, opposite polarities of the successive specimens indicate the borders between geomagnetic polarity zones.

All specimens below $46.6 \mathrm{~m}$ depth demonstrate reversed polarity of the ChRM component after AF demagnetization, while two specimens after thermal demagnetization in the R-L9L1 loess (at $50.0 \mathrm{~m}$ and $50.8 \mathrm{~m}$ depth) show normal polarity. In the depth range of $40.5-46.3 \mathrm{~m}$ many specimens display reversed polarity after thermal demagnetization procedures. A reversed polarity zone at a depth of $40.5-42.5 \mathrm{~m}$ within the R-L6 loess unit and the uppermost $0.25 \mathrm{~m}$ of the R-S6 soil corresponds to a cluster of most of these specimens. This is the only one zone which is partly (at a depth of $41.4-41.9 \mathrm{~m}$ ) confirmed by results of AF demagnetization. Examples of Zijderveld diagrams indicating a reversed polarity zone in the R-L6 loess are given in Figure 6A, D. Examples for soil specimens have been given previously (Bakhmutov et al., 2017; Hlavatskyi and Bakhmutov, 2019).

In our interpretation, the MBB is placed at the junction of the R-S7 and R-S8 palaeosol units at a depth of $46.6 \mathrm{~m}$ (Fig. 7 and Table 3). The normal polarity interval at $50.0-50.8 \mathrm{~m}$ depth is correlated with the Kamikatsura excursion ( 850-900 ka; Laj and Channell, 2007). The reversed polarity zone above the MBB, based on its stratigraphic position in several loess-palaeosol sections in the Danube Basin (Sümegi et al. 2018), is shown in the palaeomagnetic section as the "Stage 17" reversed polarity excursion (670 ka; Laj and Channell, 2007; see discussion). Previously it was compared to the Emperor/Big Lost event (560-570 ka; Bakhmutov et al., 2017).

\section{MATUYAMA-BRUNHES BOUNDARY IN THE VYAZIVOK SECTION}

Characteristic examples of thermal demagnetization of loess and soil specimens from the Vyazivok section are shown in Figure 6. In a loess specimen from the V-L2 unit the normal polarity component turned towards the origin when the temperature exceeded $270^{\circ} \mathrm{C}$ (Fig. 6B). In a palaeosol specimen from the $\mathrm{V}-\mathrm{S} 7$ unit the presence of a reversed direction at temperature $>200^{\circ} \mathrm{C}$ with an overprinted viscous normal polarity component is clearly seen in Figure $6 \mathrm{C}$. During heating, $>70 \%$ of samples showed a significant increase in MS at temperatures $>270-300^{\circ} \mathrm{C}$

AF demagnetization was performed for duplicate specimens. Examples from the V-L2 loess and V-S7 palaeosol are shown in Figure $6 \mathrm{E}$ and $\mathrm{F}$, respectively. In the loess, a high-coercivity component was not totally removed even by 100 $\mathrm{mT}$, but undoubtedly demonstrated normal polarity. In the palaeosol sample, after removing the viscous component, the high-coercivity component (up to $30 \mathrm{mT}$ ) showed reversed polarity with a tendency of going towards to the origin, but $10 \%$ of initial NRM was not demagnetized (Fig. 6F).
About half of the specimens contained a high-coercivity component which was totally removed by an 80-100 mT field, and in lowermost part of the section this ChRM component was very distinct. Other samples had a low-coercivity component which was removed by a field of $\sim 20-30 \mathrm{mT}$ and did not provide any clustered palaeodirections. After removal of this component, the stable high-coercivity component often was not totally eliminated even in a field of $100 \mathrm{mT}$. This indicates hematite as an important carrier of ChRM.

The declination and inclination directions of the ChRM component after temperature (65 specimens) and AF (37 specimens) demagnetization and the composite palaeomagnetic column are shown in Figure 8 as a function of depth in the interval $51.0-59.0 \mathrm{~m}$. The results of thermal and AF demagnetization are concordant and have similar positive inclination and northerly declination in the depth interval 51.0-56.2 m. In two specimens above $56.2 \mathrm{~m}$ (uppermost part of the V-S7 unit) after thermal demagnetization a reversed polarity was defined, though it was not confirmed by duplicate specimens treated by AF.

Directions of the ChRM component of specimens below $56.2 \mathrm{~m}$ depth have reversed polarity and belong to the Matuyama chron. Thus, the position of the MBB in the Vyazivok section has been demonstrated at a depth of $56.2 \mathrm{~m}$ in the V-S7S2 soil (subunit sh $_{1}$ according to Matviishina et al., 2001; Fig. 5C).

Only one magnetic event in the Vyazivok section was detected, a short level of reversed polarity at $25.5 \mathrm{~m}$ depth in the lowermost part of the V-S4 unit, shown by both stepwise thermal and AF demagnetization results (Hlavatskyi et al., 2016b) (see Figure 2). Below we substantiate that this is the Unnamed geomagnetic event at $430 \mathrm{ka}$ (Laj and Channell, 2007), marking the lower boundary of MIS 11.

\section{DISCUSSION}

\section{ORIGINS OF THE NRM ACQUISITION AND QUALITY} OF THE PALAEOMAGNETIC DATA

Magnetic mineral assemblages in the loess-palaeosol sequence of Ukraine mainly contain magnetite, maghemite, hematite and goethite (see review in Bakhmutov et al., 2017). Hematite is present both in loess and palaeosols, and its concentration is significantly higher in the sequences located in northern Ukraine, including the Vyazivok section (Hlavatskyi et al., $2016 b)$. It seems that periodic humidification in the territory close to the ancient ice sheet had facilitated the oxidation of ferrimagnetic grains and the formation of highly coercive minerals (Bakhmutov et al., 2017). Paramagnetic minerals also have a significant influence on magnetism of loess and palaeosols (Hlavatskyi et al., 2016a, b). At Roksolany, the NRM is carried dominantly by magnetite (Sharonova et al., 2004; Gendler et al., 2006) with a high content of superparamagnetic grains (Bakhmutov et al., 2017).

Because the NRM of loess-palaeosol sediments is a mixture of different types of remanent magnetization, it is necessary to identify the ChRM carried by detrital iron oxides to isolate the primary component of magnetization. There are three major demagnetization methods: chemical, AF and thermal demagnetization (Schmidt, 1993). It is difficult in practice to conduct chemical demagnetization on loess samples (Liu et al., 2015). AF demagnetization is often not effective at removing secondary (viscous) components from Chinese (Jin and Liu, 2011; Liu et al., 2015) and Ukrainian (Bakhmutov and Glavatskiy, 2016) loess, because low-temperature oxidation of detrital magnetite can significantly increase its coercivity. In addition, the presence of superparamagnetic grains in palaeosols 


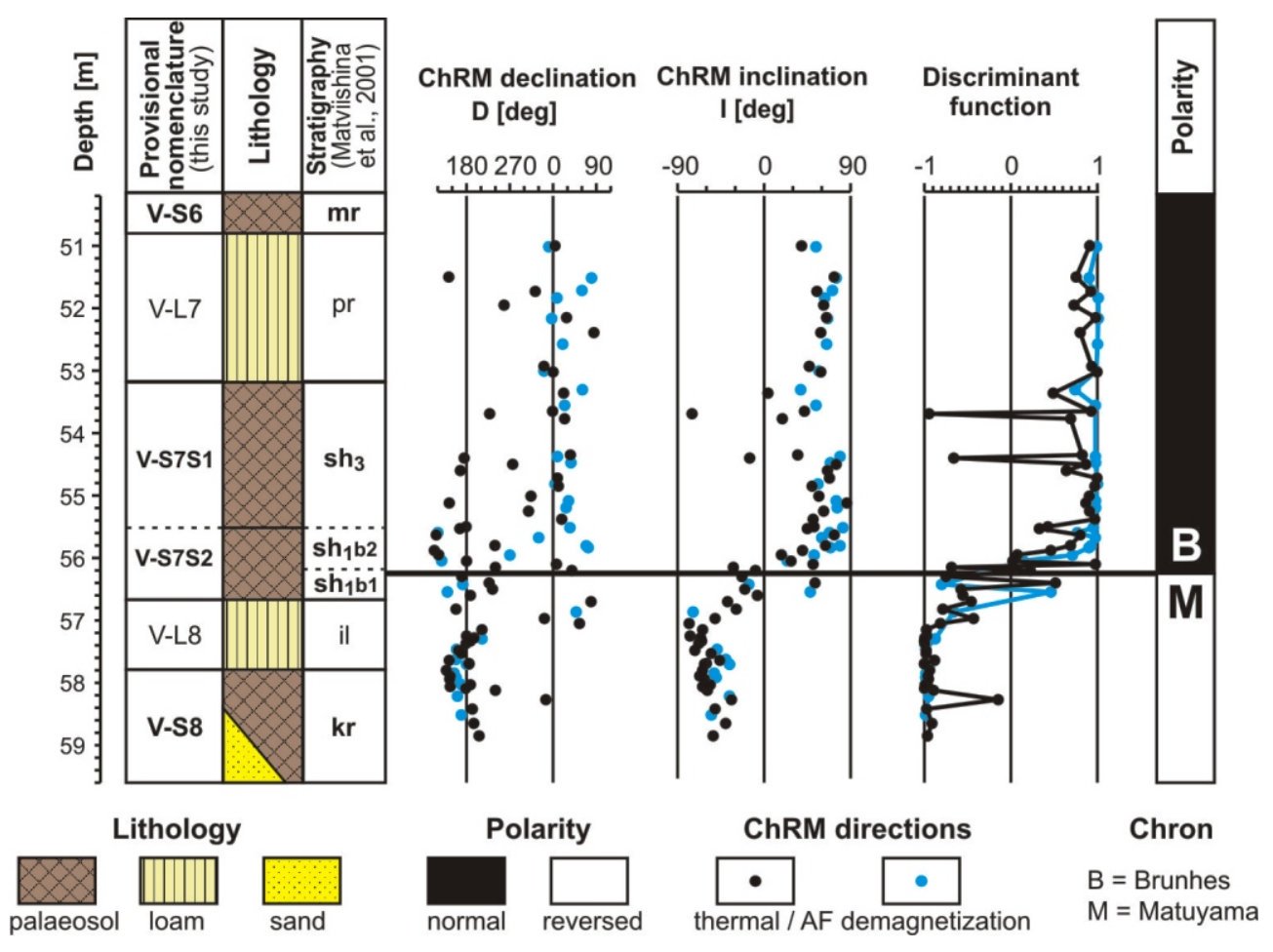

Fig. 8. Results of palaeomagnetic study of the lowermost part of the Vyazivok section

Explanation as on Figure 7

does not allow successful demagnetization of the samples without placing the equipment in a magnetically shielded space. Thermal demagnetization becomes the most widely used method to remove secondary components of magnetization overprints. Usually, in Ukrainian loess and palaeosols, heating of samples to $200-250^{\circ} \mathrm{C}$ is enough to distinguish the ChRM component (Bakhmutov and Glavatskiy, 2016).

In the loess and palaeosol samples from the Roksolany section, thermal and AF demagnetization removes a strong viscous overprint, and ChRM is $<5-10 \%$ of the initial NRM. Thus, the ChRM intensity (about $\mathrm{n} \times 10^{-5} \mathrm{~A} / \mathrm{m}$ ) could not be accurately measured, taking into account the threshold of the astatic magnetometers (LAM-22 or MA-21) which were used in the Kyiv palaeomagnetic laboratory in the 1970-1980s. Another problem was a high content of superparamagnetic grains in the palaeosols, the relaxation time of which was comparable with the measurement time $\left(n \times 10^{2} \mathrm{~s}\right)$. In our view, in the early studies, the specimens undergoing demagnetization-measurement procedures without using a magnetically shielded room had to have been strongly affected by a viscous component which finally caused wide scatter of ChRM directions. Therefore, our palaeomagnetic results for the Roksolany section are different from previous data, in which many magnetic events were identified (Tretyak, 1980, 1983; Tretyak et al., 1987). Besides these flaws, which were caused by limitations of the equipment of that time, we note that statistically significant data (continuous sampling from 60 loess sections in all regions of Ukraine) allowed constructing a unified Pleistocene magnetostratigraphic scale of Ukraine (Tretyak and Vigilyanskaya, 1994), in which the Shyrokyne unit has been included correctly into the Brunhes chron, as will be shown below.

The other palaeomagnetic results of the Roksolany section that point to the position of the MBB $12 \mathrm{~m}$ above, in the R-L4 loess unit ( $L_{6}$ in Tsatskin et al., 1998, 2001; Gendler et al.,
2006), have been described in detail in Sartori (2000). A total of 118 samples were treated using AF and thermal demagnetization. Since most of the material was fragile, the samples had to be kept in a plastic sampling box, which could not be heated to temperatures $>150^{\circ} \mathrm{C}$. For this reason, AF demagnetization had mostly to be applied. In addition, the thermal demagnetization was carried out in another laboratory by J. Hus, wherein the viscous component was removed at $250^{\circ} \mathrm{C}$ and the $\mathrm{ChRM}$ was isolated. Many samples below $34 \mathrm{~m}$ depth had a reversed polarity. According to the results of AF demagnetization, the MBB was drawn in the loess unit R-L4 $\left(L_{6}\right)$ at a depth of $34.5 \mathrm{~m}$. The thermal demagnetization data suggested the MBB at a depth of $34 \mathrm{~m}$ below the overlying R-S3S3 $\left(\mathrm{PK}_{6.2}\right)$ soil. Unfortunately, the orthogonal vector diagrams indicating reversed polarity were presented only for two specimens from depths of 46.3 and $46.6 \mathrm{~m}$, whereas the samples in the depth interval of 34 to $46 \mathrm{~m}$ cannot be assessed. The palaeomagnetic interpretation provided by Sartori (2000) and Gendler et al. (2006) disregards the results in the depth interval from 34 to $42 \mathrm{~m}$, where about one-third of specimens after thermal and half of the specimens after AF demagnetization had normal polarity. From our point of view, the authors did not give good arguments why they placed the MBB at a depth of $34 \mathrm{~m}$.

According to the palaeomagnetic study of Dodonov et al. (2006), among 22 samples from the depth interval of 34-50 m (i.e. the sampling step was $\sim 0.73 \mathrm{~m}$ ), 20 samples had reversed polarity, whereas two samples with normal polarity were compactly located in the lower (R-S7?) soil, correlated to the Jaramillo subchron. However, the authors (Dodonov et al., 2006) did not specify the measurement equipment used and the means of calculating the directions of the characteristic magnetization.

Meanwhile, our results from the Vyazivok section are in agreement with data previously obtained by Vigilyanskaya 
(2001). The polarity reversal zone has been faithfully determined from a statistically significant number of specimens. These results are consistent with the magnetostratigraphic studies of Pleistocene sections of Ukraine (Tretyak et al., 1987 1989; Tretyak and Vigilyanskaya, 1994; Vigilyanskaya and Tretyak, 2000, 2002; Vigilyanskaya, 2001) where the MBB was assigned to the lowermost part of the Shyrokyne pedocomplex. Ongoing palaeomagnetic studies of another reference Pleistocene sequence of Ukraine at Stari Kaydaky $(325 \mathrm{~km}$ SE from Vyazivok) and loess-palaeosol sections in the Podolian Upland have revealed that the MBB could not be located above palaeosol subunit $\mathrm{sh}_{1}$ (Hlavatskyi, 2019), an equivalent of V-S7S2 at Vyazivok.

\section{CONTRADICTORY STRATIGRAPHIC POSITIONS OF THE MBB}

The stratigraphic position of the MBB according to domestic lithostratigraphic subdivisions (based on the nomenclature of Veklich et al., 1984a, 1993) is different in the Roksolany (between the Lubny and Martonosha units) and the Vyazivok section (in the Shyrokyne unit). According to the conventional chronostratigraphic model (Gozhik et al., 2000; Bogucki et al., 2013) the MBB at Roksolany is located at the bottom of the palaeosol unit corresponding to MIS 13-15, while at Vyazivok the MBB lies in the lower part of the pedocomplex, which was correlated by Matviishyna et al. (2010) with MIS 21-37 (Tables 1 and 2). The reason for these contradictions could be as follows: (1) lock-in depth hypothesis - delay of the Matuyama-Brunhes palaeomagnetic record within the Vyazivok section; (2) stratigraphic incompleteness of the Roksolany section; (3) incorrect stratigraphy of one of the sections.

Hypothesis 1. In the magnetostratigraphic records of Chinese loess-palaeosol profiles, the MBB is observed in loess layer L8 (Zheng et al., 1992; Spassov et al., 2001, 2003; Ding et al., 2002; Pan et al., 2002), which was deposited during a glacial period. In some publications (such as Yang et al., 2010), the MBB in the regions with developed pedogenesis is located in loess L8 too (Baoji section). These studies have revealed the problem of a climatostratigraphic inconsistency in the position of the Matuyama-Brunhes reversal in terrestrial and deep-sea records: the MBB is recorded in the loess unit (representing a cold period), but in MIS 19 in marine sediments (representing a warm period; Bolshakov, 1996, cited in Bolshakov, 2008; Tauxe et al., 1996).

Hyodo (1984), Hus and Han (1992), pointed out that different post-depositional remanent magnetization lock-in depths may explain the different stratigraphic positions of the MBB. Zhou and Shackleton (1999), and Spassov et al. (2003) proposed a large lock-in depth interval $(\sim 2-3 \mathrm{~m})$ for the MBB in the Chinese loess. Three mechanisms could explain such a large downward displacement of the MBB: (1) large postdetrital remanent magnetization lock-in effects (Zhou and Shackleton, 1999); (2) delayed acquisition of a (bio-)chemical remanent magnetization (Spassov et al., 2003); and (3) incorrect interpretation of the position of MIS boundaries within loess sequences based on the MS correlations (Liu et al., 2008). The observed multiple polarity changes of the ChRM component are not features of the geomagnetic field during the magnetic reversal They are caused by variable relative contributions of detrital and pedogenic magnetization components, which give rise to irregular polarity lock-in at the MBB (Spassov et al., 2003). According to this interpretation, the inferred position of the MBB in loess sequences of the CLP was re-positioned higher within L8-S7 zone. The palaeosol unit S7 is correlated with MIS 19, and S8 with MIS 21 (Spassov et al., 2003). Similarly, in the most representative loess sequence of Serbia, Stari Slankamen, the position of the MBB has been lowered: initially it was identified in loess L9 (MIS 22) according to AF demagnetization results (Marković et al., 2011), and later in palaeosol S8 (MIS 21) following thermal and hybrid demagnetization procedures (Song et al., 2018).

Taking into account the lock-in model it is possible to re-position the MBB in the Vyazivok section upwards by at most $3.0 \mathrm{~m}$ into the upper part of the V-S7 soil (still the Shyrokyne unit). The distance between the shifted position of the MBB in V-S7 and inferred position at the top of the V-S6 (Martonosha) soil reaches, however, more than $10 \mathrm{~m}$, which definitely excludes the possibility of applying the lock-in hypothesis.

Furthermore, we should take into account that loess sediments are affected by soil formation processes less than are soils (Bolshakov, 2008). The overprinting effect of chemical magnetization in loess is less significant and loess units can serve as a barrier against lock-in depth effects. If the Matuyama-Brunhes reversal is synchronous with the formation of a part of a soil layer, the palaeomagnetic record of the reversal in general cannot be displaced appreciably below the boundary between the soil and underlying loess (Bolshakov, 2008). The V-L7 (Pryazovya) loess unit in the Vyazivok section has normal polarity, which excludes secondary processes overprinting the palaeomagnetic record in the V-S7 soil.

Thus, the Shyrokyne unit at Vyazivok belongs to the Brunhes chron and most likely should be re-correlated with MIS 19, supporting our previous suggestion (Hlavatskyi, 2019).

Some authors (e.g., Wang et al., 2006; Bolshakov, 2017; Jin et al., 2019) have questioned the lock-in depth hypothesis. They considered singling out nine palaeosol units within the Brunhes chron (S0 to S8, where S8 instead of S7 corresponds to MIS 19), including still only one MIS 13-15 pedocomplex and an additional MIS 18.2 interstadial soil (Wang et al., 2006), or separate MIS 13 and MIS 15 units (Bolshakov, 2017; Jin et al., 2019). This interpretation is supported by data from the Luochuan, Sunmenxia, Jixian and Baicaoyuan sections in the central and southeastern part of the CLP (Heller and Liu, 1984; Wang et al., 2006, 2014; Jin and Liu, 2011; Liu et al., 2015; Jin et al., 2019), where the Matuyama-Brunhes reversal is fixed in palaeosol S8 below L8. Thus, there remains a discrepancy in the Chinese loess chronostratigraphy.

Hypothesis 2. This is stratigraphic incompleteness of the lowermost part of the Roksolany section. According to the stratigraphy of Gozhik et al. (2000) and Bogucki et al. (2013), assigning two interglacials in the Lubny (corresponding to MIS 13 and MIS 15) and Martonosha (MIS 17 and MIS 19) units, a mismatch of the chronostratigraphic position of the MBB is noticeable. Since the MBB corresponds to MIS 19, the R-S7 unit which is marked as Lubny by Gozhik et al. $(2000,2007)$ and Bogucki et al. (2013) should be correlated with MIS 19. Thus, the correlation with the MIS scale in Gozhik et al. (2000) and Bogucki et al. (2013) becomes correct if two additional interglacial units can be included into the Brunhes section of the Roksolany sequence. However, this implies that the stratigraphy the Roksolany profile is incomplete, in contrast to the widespread opinion that the Roksolany section is one of the most complete among Pleistocene loess-palaeosol sequences of Eastern Europe (Bogutskyi and Tomenyuk, 2013).

In order to break the impasse on that issue, a revised lithostratigraphy of the lowermost part of the section by the same research team (Gozhik et al., 2007; Bogucki et al., 2013; Łanczont et al., 2015) was recently given (Nawrocki et al., 2018: fig. 1). In upgraded stratigraphic column, the lithostratigraphic unit corresponding to the Martonosha soil (R-S8) is not shown. The Martonosha unit was moved up to the place of the Lubny soil (R-S7), and the Lubny unit was moved upwards into the 
place of the lower Zavadivka soil (R-S6S2), so the Zavadivka unit was reduced. The MBB cited from Bakhmutov and Hlavatskyi (2014) was placed in the upper part of the relocated Martonosha (former Lubny) unit correlating with MIS 17-19 (instead of MIS 13-15), without any detailed explanation for the reason of the change. As stated before in Bakhmutov and Hlavatskyi (2014) and Bakhmutov et al. (2017), the MBB has been defined at the contact of two soil units - the Lubny and Martonosha according to the stratigraphy of Gozhik et al. (2000, 2007) and Bogucki et al. (2013). The lower soil unit is characterized by individual lithopedological properties and occupies a definite stratigraphic position in the Roksolany section (Gozhik, 1976; Tretyak, 1980, 1983; Gozhik et al., 1995, 2000, 2007; Bogucki et al., 2013; Bakhmutov and Hlavatskyi, 2014; Bakhmutov et al., 2017).

We do not support the hypothesis of lithostratigraphic incompleteness of the lowermost part of the Roksolany section. As noted above, there is evidence suggesting that this is a well-developed sequence. By contrast, we support the idea of more balanced revisiting of the stratigraphic subdivision (see Hypothesis 3).

Hypothesis 3. Another option to solve this problem requires a complete revision of the current stratigraphic subdivision of the entire Roksolany sequence by Gozhik et al. (2000, 2007) and Bogucki et al. (2013) towards older ages. The following are some examples of incorrect stratigraphy:

The original chronostratigraphic subdivision of the Roksolany sequence is based on radiocarbon $\left({ }^{14} \mathrm{C}\right)$ and thermoluminescence (TL) ages, obtained in 1975 (Gozhik, 1976; Tretyak, 1980; Guidebook, 1982; see also fig. 4 in Dodonov et al., 2006) and reprocessed in 2003-2004 (Gozhik et al., 2007; Gozhik, 2013; Fig. 9). According to these data the sedimentation rate was changing dramatically. For example, the uppermost $15.5 \mathrm{~m}$ of the section (from the R-L2 loess to the R-L1S1 soil) was formed 30-10 ka (i.e. the sedimentation rate exceeds $77.7 \mathrm{~cm} / \mathrm{ky}$ ), while the $2 \mathrm{~m}$ thick layer of R-S8 and R-S7 formed 800-472 ka (implying a sedimentation rate of $\sim 0.6 \mathrm{~cm} / \mathrm{ky}$ ). Consequently, the thickest unit R-L2 (the Bug loess, bg, of Gozhik et al., 2000, 2007 and Bogucki et al., 2013), the well-developed palaeosol R-S1 (Dofinivka, df) and the uppermost loess R-L1 with R-L1S1 soil (Prychornomorya, pč) are correlated with MIS 2. We have no other evidence of such high accumulation rates at the end of last glacial period in loess sequences from the Lower Danube Basin or western Black Sea shore.

Such young ages of the uppermost part of the Roksolany section were not supported by results of optically stimulated luminescence (OSL) and TL dating listed in Fedorowicz et al. $(2012,2013)$. According to them, all OSL ages range from 97 to $164.6 \mathrm{ka}$, and TL ages from 64.8 to $222.0 \mathrm{ka}$. In the uppermost part of the R-L2 (Bug) loess, OSL and TL dating data showed an inversion; nonetheless, they correlate well with each other and correspond to an Eemian and Early Weichselian age (MIS 5) unlike the previous data of Gozhik et al. (2007).

An important feature of the Roksolany section is a volcanic ash layer, the "Roksolany Tephra", in the uppermost part of the R-L2 loess, $1.3 \mathrm{~m}$ below R-S1, correlated with the MIS 2 by Gozhik et al. (2000, 2007), Bogucki et al. (2013) and Gozhik (2013). Minerals from this volcanic ash have been dated by different methods with the following results: Ar-Ar - $50 \pm 3 \mathrm{Ma}$ (Tsatskin et al., 1998; Sartori, 2000); K-Ar (on amphibole and biotite) - $12.3 \pm 0.15 \mathrm{Ma}, 11.9 \pm 0.15 \mathrm{Ma}, 14.5 \pm 0.15 \mathrm{Ma}$ (Fedorowicz et al., 2012); and fission track - >12 Ma (Gozhik, 2013). Gozhik (2013) and Fedorowicz et al. (2013) argued that material so old was not the product of a volcanic eruption. Moreover, based on luminescence dating results, Fedorowicz et al. (2013) suggested that the Roksolany Tephra layer was redeposited $\sim 100$ ka.

In succeeding publications concerning the Roksolany Tephra layer (Łanczont et al., 2015; Wulf et al., 2016), only one OSL age $33.1 \pm 2.6 \mathrm{ka}$ from $18.7 \mathrm{~m}$ depth in the R-L2 (Bug) loess was reported. The uppermost three soils (R-L1S1, R-S1, R-S2) were dated by similar accelerator mass spectrometry ${ }^{14} \mathrm{C}$ ages in the range of $\sim 25,890-17,970 \mathrm{BP}$ (calibrated age range $34,002-21,357$ cal. yr BP). The dated samples were taken from humus horizons with minimal humus substance $(0.18-0.20 \%)$ and did not contain wood charcoal material (Łanczont et al., 2015: 434). The ash specimens analysed from the Mohoş crater of the Ciomadul volcano in Romania revealed ${ }^{14} \mathrm{C}$ ages of $23,529 \pm 348$ BP and 25,438 \pm 207 BP (Wulf et al. 2016: table 2). Geochemical analysis (Wulf et al., 2016) and ages of pyroclastic zircons (470-840 ka with a peak between 500 and 750 ka; Nawrocki et al., 2018) had established that the Roksolany Tephra was derived from the Ciomadul volcano. It remains unclear to us why Łanczont et al. (2015) and Wulf et al. (2016) rejected the more statistically significant sample of older OSL ages from the R-L2 (Bug) loess, and what was the reason of assigning R-S2 (Vytachiv, vt) rather than, for example, the $\mathrm{R}-\mathrm{L} 1 \mathrm{~S} 1$ soil to MIS 3 according to ${ }^{14} \mathrm{C}$ data. Notably, Dodonov et al. (2006) obtained earlier a similar date of 26,640 \pm 240 cal. yr BP for the R-L1S1 unit and correlated it with the Bryansk soil (MIS 3).

In addition, Constantin et al. (2019) have just published new OSL ages for the uppermost loess R-L1L1 (L1 according to the nomenclature of Constantin et al., 2019): $16.6 \pm 1.1$ ka at $0.87 \mathrm{~m}$ depth and $21 \pm 1.4 \mathrm{ka}$ at $1.37 \mathrm{~m}$ depth. These authors concluded that the loess was deposited during the Last Glacial Maximum.

These chronological ages are shown in Figure 9 and demonstrate the inconsistency of data obtained by different authors.

\section{MS STRATIGRAPHY AND CHRONOSTRATIGRAPHY} OF THE VYAZIVOK SECTION

Before revisiting the chronostratigraphy of Roksolany, it is necessary to refine first the chronology of the Vyazivok section, since there are no discrepancies about its lithostratigraphic subdivision. For comparison of the MS record at Vyazivok with the MIS scale, the ODP 677 benthic $\delta^{18} \mathrm{O}$ curve reflecting global ice volume (Shackleton et al., 1990) was selected. In our correlations, we use the lettered marine isotope substages adopted by Railsback et al. (2015). The structures of the MS curve and ODP 677 record are very similar and show a number of interesting consequences for chronological patterns (Fig. 3). That allows the development of a chronostratigraphy for the Vyazivok section as the best developed reference loess-palaeosol sequence in Ukraine.

The main difference in the stratigraphic models proposed for the loess-palaeosol sequences of Ukraine (Table 2), is the chronological placement of the Kaydaky pedocomplex (kd) and the Dnipro loess (dn; previously spelled Dnieper). Some authors (Rousseau et al., 2001; Vozgrin, 2001; Gerasimenko, 2004, 2006; Buggle et al., 2008, 2009; Matviishyna et al., 2010) correlate the Kaydaky unit with MIS 5 e and the Dnipro unit with MIS 6, while others (Veklich, 1995; Gozhik et al., 2000; Lindner et al., 2004, 2006; Bogucki et al., 2013; Łanczont et al., 2015) correlate these units with MIS 7 and MIS 8.

At Vyazivok, the Kaydaky pedocomplex (V-S1S2) is represented by a light-grey forest soil overlying the Dnipro loess (V-L2). The V-L2 unit is associated with the moraine of the Dnieper (Saalian) glaciation (Veklich et al., 1967; Matviishina et al., 2001). The V-S1S1 (Pryluky, pl) pedocomplex contains a 


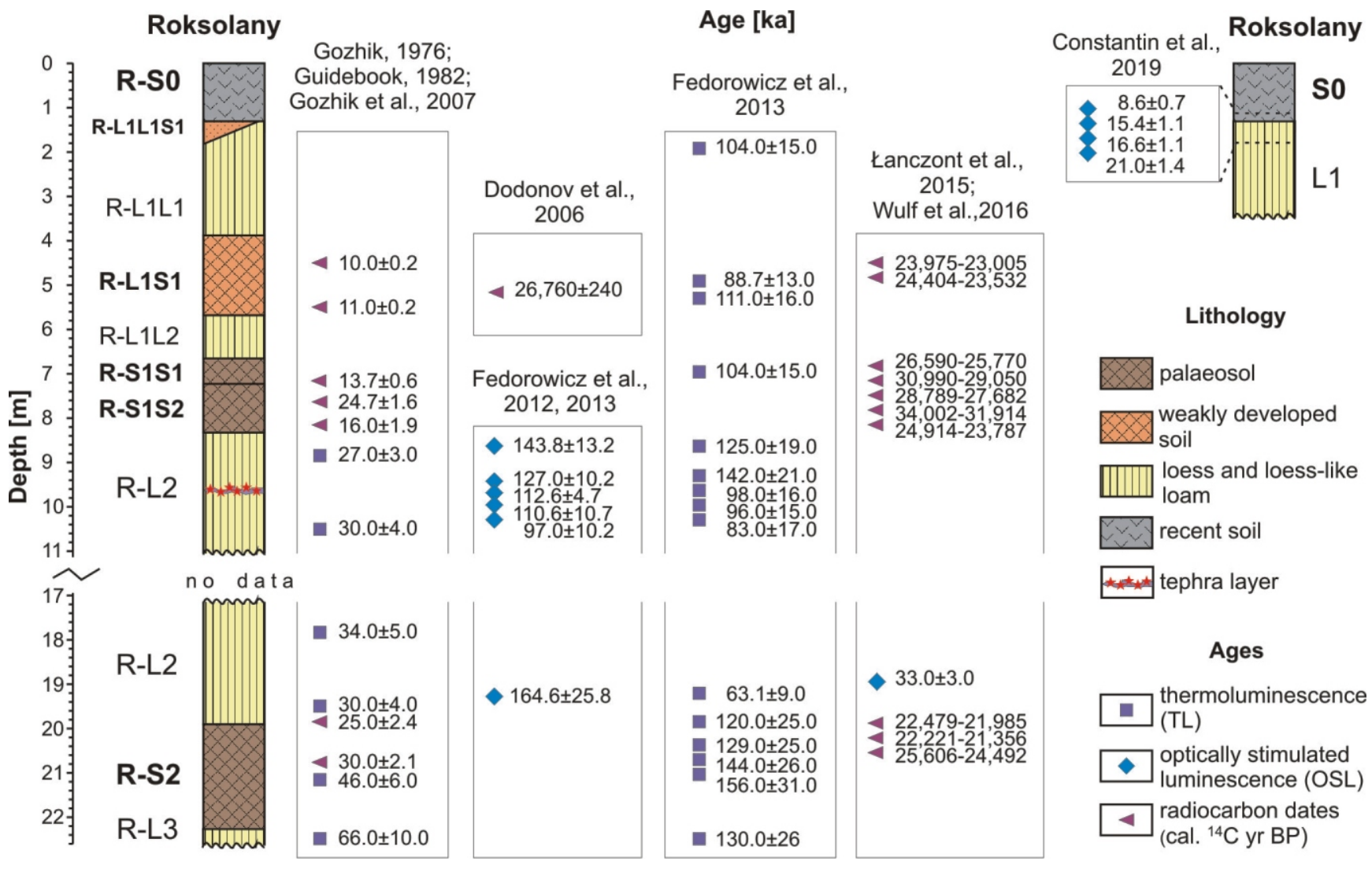

Fig. 9. Luminescence and radiocarbon dating of the uppermost part of the Roksolany section

On the left - our stratigraphic nomenclature, on the right - schematic inset of the lithostratigraphic column with the stratigraphic nomenclature of Constantin et al. (2019)

meadow forest $\left(\mathrm{pl}_{\mathrm{b}}\right)$ and meadow steppe $\left(\mathrm{pl}_{\mathrm{c}}\right)$ brown chernozem-like palaeosol, and is separated by thin pedogenetically altered loess V-S1L1 (Tyasmyn) from the V-S1S2 pedomplex. The three-peaked MS record of V-S1 (Fig. 3) is very similar to the pattern of the benthic $\delta^{18} \mathrm{O}$ record of MIS 5 as well as to the MS pattern of the SK-S1 pedocomplex in the Stari Kaydaky section (Buggle et al., 2009). The MS record of the V-S1 unit likewise corresponds well to previous data (Rousseau et al., 2001).

Taking into account the MS curve at Vyazivok and the marine $\delta^{18} \mathrm{O}$ record in the range of MIS 5-7 we correlate the V-S1S1 pedocomplex with MIS $5 \mathrm{a}-\mathrm{c}$, the V-S1L1 loess with MIS $5 \mathrm{~d}$, the V-S1S2 pedocomplex with MIS 5e, and the V-L2 loess with MIS 6. Amino acid ratios of mollusk shells found within Dnipro deposits indicate they are of MIS 6 age (Oches et al., 2000, cited in Rousseau et al. 2001), corroborating the accuracy of our correlation. This interpretation supports the stratigraphic schemes of Rousseau et al. (2001), Vozgrin (2001), Gerasimenko (2004, 2006), Buggle et al. (2008, 2009) and Matviishyna et al. (2010).

A weakly developed soil, V-L1S1 (Vytachiv), is located above the last interglacial pedocomplex V-S1 being separated from it by the V-L1L2 (Uday, ud) loess. The V-L1S1 pedocomplex is represented by two subunits $\left(\mathrm{vt}_{\mathrm{b} 1}\right.$ and $\left.\mathrm{vt}_{\mathrm{b} 2}\right)$ with a layer of weakly pedogenetically altered loess between them ( $\mathrm{vt}_{\mathrm{b} 2-\mathrm{b} 1}$; Matviishina et al., 2001; Rousseau et al., 2001). The V-L1S1 unit has low values of MS, comparable to background MS of loess. Considering the stratigraphic position of the V-S1 pedocomplex we attribute the V-L1S1 to MIS 3, as suggested by Rousseau et al. (2001), Gerasimenko (2004, 2006) and Matviishyna et al. (2010).

Overlain by the V-L2 loess, the V-S2 pedocomplex (Potyagaylivka, pt) is represented by a polygenetic soil, an upper chernozem-like soil $\mathrm{pt}_{\mathrm{b} 2}$ and a lower brown forest loessified soil $\mathrm{pt}_{\mathrm{b} 1}$ (Gerasimenko and Matvijishyna, 2007). Strong cryogenic deformation is a characteristic of the pedocomplex (Matviishina et al., 2001). We correlate the V-S2 unit with MIS 7 (as did Gerasimenko and Matvijishyna, 2007) based on two MS peaks with a dominant upper peak. Thus, the MS pattern corresponds to the characteristic twin peak association in the Serbian and Romanian palaeosol S2 (Buggle et al., 2009; Marković et al., 2015; Necula et al., 2015).

The underlying thin loess V-L3 (Oril) shows cryofeatures penetrating into the V-S3 palaeosol. Despite its pedogenic overprint from the overlying pedocomplex, V-L3 is attributed to glacial conditions, i.e. representing MIS 8.

The V-S3 unit (Upper Zavadivka, $\mathrm{zv}_{3}$ ) is a strongly developed pedocomplex composed of brown warm forest soils. It includes a lower $z_{3 \mathrm{~b} 1}$ and middle $z_{3 \mathrm{~b} 2}$ grey-brown soil (corresponding to early and late pedogenesis optima after Matviishina et al. (2001), respectively), and the upper complex reddish-brown soil $z v_{3 c}$ (the final pedogenesis phase) with an extended carbonate (Bca) horizon. The V-S4 pedocomplex (Lower Zavadivka, $\mathrm{zv}_{1}$ ) includes the lower yellowish-brown calcareous soil $\mathrm{Zv}_{1 \mathrm{a}}$ (initial pedogenesis phase), middle dark-brown soil $z_{1 \mathrm{~b} 1}$ and upper grey-brown meadow heavy-loam soil $z v_{1 b 2}$ (early and late pedogenesis optima, respectively; field description of Zh. Matviishyna, personal com- 
munication, 2014). The V-S3 and V-S4 palaeosols are divided by a thin cryogenesis level. The V-S3 and V-S4 units undoubtedly correspond to individual interglacials, MIS 9 and MIS 11, respectively, as suggested previously by Gerasimenko and Matvijishyna (2007). The MS pattern shows the complex structure of both palaeosol units: each pedocomplex is characterized by separate MS peaks in each soil subunit and corresponding MIS substage (Fig. 3). Despite the erosional incision of the V-S3 palaeosol, similar to the MS record of the MIS 9 soil at Koriten (Bulgaria; Jordanova and Petersen, 1999), Paks (Hungary; Sartori, 2000), Viatovo (Bulgaria; Jordanova et al., 2007), Stari Kaydaky (Ukraine), Mircea Voda (Romania; Buggle et al., 2009), Batajnica (Serbia; Marković et al., 2009, cited in Marković et al., 2015) and Costineşti (Romania; Necula et al., 2015), it shows relatively high magnetic enhancement.

In the lowermost part of the V-S4 palaeosol a short zone of reversed polarity has been established (Hlavatskyi et al., 2016b). We attribute it to the Unnamed magnetic event with an age of $\sim 430 \mathrm{ka}$ (Table 3 ). The same excursion has been found in the Udvari-U2 section at the base of the U2-S4 palaeosol (Sümegi et al., 2018) and corresponds with the beginning of the MIS 11 in both sections.

The V-L5 loess (Tyligul, tl) is the second thickest loess unit at Vyazivok (almost $11 \mathrm{~m}$ thick) after V-L2 and corresponds to MIS 12. After $\sim 520 \mathrm{ka}$, loess accumulation rates increased in response to relatively more steppe-like, arid environments.

The V-S5 unit (Lubny) is a pedocomplex of three soils. The upper one, V-S5S1 ( $\mathrm{lb}_{\mathrm{c}}$ according to Matviishina et al., 2001), is a brownish-grey soil leached of carbonates, the middle one, V-S5S2 $\left(\mathrm{Ib}_{\mathrm{b} 2}\right)$, is a dark-grey meadow chernozem-like soil, and the lower one, V-S5S3 $\left(\mathrm{Ib}_{\mathrm{b} 1}\right)$, is a mottled-brown gley forest soil. In the Middle Dnieper area, the Lubny unit contains two main pedocomplexes $\left(\mathrm{Ib}_{1}\right.$ and $\left.\mathrm{Ib}_{3}\right)$, each of which consists of a lower forest soil and upper chernozem-like soil. The pedocomplexes are commonly separated by a loess $\left(0.6-1 \mathrm{~m}\right.$ thick) subunit $\left(\mathrm{Ib}_{2}\right.$; Matviishina et al., 2001). The soils were formed under temperate climatic conditions; the first interglacial $\left(\mathrm{lb}_{1}\right)$ was warmer. The Lubny unit according to Ukrainian stratigraphy unquestioningly corresponds to MIS 13-15 (Matviishyna et al., 2010; Gozhik and Gerasimenko, 2011).

At Vyazivok, the low MS values of $\mathrm{V}$-S5 are the same as in adjacent loess units. In the reference loess-palaeosol sequence of Hungary, the Udvari-U2 section (Sümegi et al., 2018), the MS values for the U2-S5 unit (MIS 13-15) are likewise low as at Vyazivok. The stratigraphic position of the V-S5 unit in the Vyazivok section indicates that it should be equivalent only to MIS 13-15.

The lower third thickest (up to $6.3 \mathrm{~m}$ thick) loess at Vyazivok, the V-L6 (Sula) unit, we likewise correlate with the glacial corresponding to MIS 16 , which is globally estimated as one of the strongest glaciations (Lisiecki and Raymo, 2005).

The V-S6 (Martonosha) pedocomplex consists of two thick meadow-cinnamonic soils, V-S6S1 $\left(\mathrm{mr}_{\mathrm{b} 2}\right)$ and V-S6S2 $\left(\mathrm{mr}_{\mathrm{b} 1}\right)$. MS measurements revealed low values, similar to those in the V-S5 unit (Fig. 3). Low values of MS in the well-developed U2-S6 (MIS 17) palaeosol were also reported for the Udvari-U2 section (Sümegi et al., 2018). The corresponding V-S6 palaeosol (MIS 17) at Vojvodina is likewise well-developed despite having similarly weak MS values (Marković et al., 2011). Taking into account the lower position of the MBB in the V-S7 palaeosol, we correlate the entire V-S6 unit with MIS 17, and the lower V-L7 loess unit (Pryazovya) with MIS 18.

The V-S7 (Shyrokyne) pedocomplex consists of two palaeosols. Considering the position of the MBB in the lower reddish-brown soil complex V-S7S2 $\left(\mathrm{sh}_{1}\right)$ and MS pattern of the upper thicker brown soil V-S7S1 $\left(\mathrm{sh}_{3}\right)$, somewhat similar to the benthic $\delta^{18} \mathrm{O}$ record of MIS 19 (Fig. 3), we correlate the V-S7 unit with MIS 19.

According to Quaternary stratigraphic studies of Ukraine (Gozhik and Gerasimenko, 2011), the Shyrokyne stage contains the last two interglacials within the Matuyama reversal: the $\mathrm{sh}_{3}$ (i.e. V-S7S1 at Vyazivok) and $\mathrm{sh}_{1}$ (V-S7S2) soils, divided by a thin $\left(0.5-1 \mathrm{~m}\right.$ ) loess-like or grey loam $\mathrm{sh}_{2}$ (not present at Vyazivok). The climate during the Middle Shyrokyne substage $\left(\mathrm{sh}_{2}\right)$ was less harsh than during the Berezan or Illichivsk stages (Matviishyna et al., 2010; Gozhik and Gerasimenko, 2011; Sirenko, 2019). In the Stari Kaydaky section, the Shyrokyne pedocomplex belongs to the normal-polarity Brunhes chron and is represented by a succession of thick chocolate-brown $\left(\mathrm{sh}_{3}\right)$ and fiery-brown $\left(\mathrm{sh}_{1}\right)$ clayey soils with a reddish-brown loam and dark humus layer in between ( $\mathrm{sh}_{2}$; Hlavatskyi, 2019). But the middle subunit $s_{2}$ indicates a warm environment rather than the fully fledged cold climatic conditions of a separate glaciation. Furthermore, in representative loess-palaeosol sections across the European loess belt (see review in Bradák et al., 2019 and references therein), the well-developed MIS 19 soil is characterized by the most intense palaeosol-forming environment, even stronger than the pedogenic enhancement of the MIS 11 soil. We suggest that the development of the lower V-S7S2 $\left(\mathrm{sh}_{1}\right)$ and upper V-S7S1 $\left(\mathrm{sh}_{3}\right)$ soils may be associated with different pedogenesis phases of the single Shyrokyne stage corresponding to MIS substages 19c and 19a, respectively (Figs. 3 and $5 \mathrm{C}$ ).

The thin V-L8 (Illichivsk) loess-like loam below the V-S7 pedocomplex is attributed to MIS 20.

Consequently, we correlate the marine $\delta^{18} \mathrm{O}$ pattern of MIS 21 with the next MS peaks corresponding to the $\mathrm{V}$-S8 reddish soil (Kryzhanivka), as shown in Figure 3 . This suggestion partly supports the correlation model of the East European Plain stratigraphic schemes developed by Bolikhovskaya and Molodkov (2006).

The V-S8 complex is underlying by white sands (the alluvium of the Kryzhanivka unit). According to Veklich et al. (1967), alluvium is extensively distributed in the area.

\section{CHRONOSTRATIGRAPHIC REVISIONS OF THE ROKSOLANY SECTION}

In the Roksolany section, the MS peak in the R-S1 pedocomplex (Dofinivka interstadial MIS 2 palaeosol after Gozhik et al., 2000, Bogucki et al., 2013 and Łanczont et al., 2015; or MIS 7-11 pedocomplex $\mathrm{PK}_{3}$ after Tsatskin et al., 2001), consisting of three well-developed bright-brown (two upper soils combined into the R-S1S1 subunit) and grey chernozem-like (lower subunit R-S1S2) forest-steppe and steppe soils, we correlate with MIS 5 (Fig. 3). The specific MS pattern of the R-S1 unit is very similar to that in the MIS 5 palaeosol at the Costineşti (Necula et al., 2015), Zimnicea (Romania; Rădan, 2012 cited in Marković et al., 2015), Ruma, Irig, Batajnica, Stari Slankamen (Serbia; Marković et al., 2015), Koriten (Jordanova and Petersen, 1999), and Lubenovo and Viatovo (Bulgaria; Jordanova et al., 2007) loess-palaeosol sections as well as to the stacked Chinese MS record (Sun et al., 2006 cited in Fitzsimmons et al., 2012). For detailed comparison of the MS records from different European loess profiles extending to MIS 5 see the illustrations in Fitzsimmons et al. (2012: fig. 4), Marković et al. (2015: fig. 4) and Necula et al. (2015: fig. 10).

Our field observations and palaeopedological data of Tsatskin et al. (1998) and Bogucki et al. (2013) suggest that the $\mathrm{R}-\mathrm{S} 1$ unit is the youngest well-developed palaeosol complex, 
genetically similar to the modern chernozem R-SO, and thus should correspond to an interglacial and not an interstadial event(s). Gozhik et al. (2000), Bogucki et al. (2013) and Łanczont et al. (2015) correlate the lower R-S3 pedocomplex at 30-33 m depth with MIS 5 (marked as the Pryluky unit), and the R-S4 pedocomplex at 34-35 m depth with MIS 7 (the Kaydaky unit). Strong rubification, analogous to that seen in the R-S3 and R-S4 palaeosols, is not typical of the Pryluky and Kaydaky soils in the loess-palaeosol succession of the entire Ukraine (Matviishyna et al., 2010), including the area studied (Veklich, 1968; Sirenko and Turlo, 1986), and of the MIS 5 pedocomplex (S1) in sequences located more southwards in the Danube Basin (Obreht et al., 2016). Veklich (1968: 107) pointed out that extraordinary feature of the Roksolany section. In our opinion, grey and brownish chernozem-like steppe and forest-steppe MIS 5 soils in the region, as pedological features, are best exemplified at Roksolany by the R-S1 palaeosol.

Another overlying R-L1S1 unit, consisting of two weak brown and greyish soils, has a MS peak at the base of the pedocomplex. This unit is comparable to MIS 3. High MS values in the lower MIS 3 soil were also reported for loess sequences from southeastern Europe (Buggle et al., 2009). The uppermost thin weakly developed soil R-L1L1S1, placed just below the Holocene soil R-S0, was not named in Bogucki et al (2013) and absent in Tsatskin et al. (1998).

Our chronostratigraphic interpretation of the uppermost units of the Roksolany section is in agreement with previous and recent studies of several loess-palaeosol sequences in the western part of the Black Sea Lowland. Vozgrin (2001) and Tecsa et al. (2020) suggested that the upper palaeosols by their pedomorphological characteristics should belong to the Vytachiv (MIS 3), Pryluky (MIS 5a-c) and Kaydaky (MIS 5e) units (rather than to the Dofinivka pedocomplex). In most loess sections in Ukraine the latter two are welded and not separated by the Tyasmyn loess (Veklich, 1968, 1982; Sirenko and Turlo, 1986; Bolikhovskaya and Molodkov, 2006; Gerasimenko, 2006; Matviishyna et al., 2010). Furthermore, the thickest loess unit (second from the top) should be associated with the Dnipro unit (MIS 6), but not with the Bug loess (as suggested by Gozhik et al., 2000, Bogucki et al., 2013 and Łanczont et al., 2015). The Roksolany palaeosols R-L1L1S1, R-L1S1, R-S1S1 and R-S1S2 thereby correspond to the Dofinivka, Vytachiv, Pryluky and Kaydaky units, respectively. Consequently, the thickest R-L2 (Bug) loess should be reassigned to the Dnipro unit and MIS 6 . Thus, the Dnipro stage, represented by extremely well developed loess units in the Roksolany and Vyazivok sections, is correlated with MIS 6.

OSL dating results after Fedorowicz et al. $(2012,2013)$ and Constantin et al. (2019) from the upper loess layers at Roksolany support our interpretation and are consistent with similar luminescence ages of L1 and L2 loess obtained in the Kurortne section (Tecsa et al., 2020), $25 \mathrm{~km}$ south of Roksolany, and the nearest Romanian, Bulgarian and Serbian sequences (see Necula et al., 2015, Constantin et al., 2019, Lomax et al., 2019 and references therein). The Roksolany Tephra layer in the uppermost part of R-L2 potentially can be correlated with, widespread in the Danube - Black Sea loess-palaeosol sequences, the "L2 Tephra" (Fig. 1), dated as $145 \pm 12 \mathrm{ka}$. This was named after its position in the loess unit L2, equivalent to MIS 6 (Marković et al., 2015 and references therein). All this is in line with the OSL date of $143.8 \pm 12.3 \mathrm{ka}$ and TL date of $142.0 \pm 21.0 \mathrm{ka}$ (Fig. 9) obtained by Fedorowicz et al. $(2012,2013)$ and the proposed MIS 6 age of R-L2. It is significant that the Roksolany site is located on the same straight line connecting the lower Danube loess sequences with the L2 Tephra layer identified at Mircea Voda (Laag et al., 2018),
Moştistea (Balescu et al. 2010) in Romania, Harletz (Lomax et al., 2019) in Bulgaria, and the volcanic fields in the southern Italian area (Fig. 1). The origin of the L2 Tephra remains unclear (Marković et al., 2015). Laag et al. (2018), considering the 150-160 ka age of tephra layers found in Lake Ohrid (Macedonia) and in the Fucino lacustrine basin (Italy), and the increasing thickness of the L2 Tephra from northern Serbia towards the south, similarly inferred that it originated in the Neapolitan area. A Ciomadul provenance of the Roksolany Tephra is also possible because this volcano was active for at least the past 250-200 ky (Karatson et al., 2013 and Harangi et al., 2015, fide Wulf et al., 2016).

Between the R-S1 and R-S3 pedocomplexes there is one more well-developed palaeosol R-S2 (Vytachiv unit, MIS 3 in Gozhik et al., 2000, Bogucki et al., 2013 and Łanczont et al., 2015; or $\mathrm{PK}_{4}$ pedocomplex, MIS 13-15 in Tsatskin et al., 2001) at the depth of 20-22 m. It is a strong red-brown polygenetic palaeosol (chernozem with signs of rubification), morphologically different from chernozem-like palaeosols encountered in the section above (Tsatskin et al., 1998). Undoubtedly, this strongly developed palaeosol should correspond to interglacial conditions. In its pedological features it is comparable to the V-S2 polygenetic chernozem-like soil (Potyagaylivka) at Vyazivok.

The R-S2 soil consists of thick humus (A) and Bca horizons. MS values in the uppermost red-brown $A$ horizon are the highest in the section with the maximum at the top: $82 \times 10^{-8} \mathrm{~m}^{3} \mathrm{~kg}^{-1}$ according to our measurements (Fig. 3) or $95 \times 10^{-8} \mathrm{~m}^{3} \mathrm{~kg}^{-1}$ according to Tsatskin et al. (1998). This palaeosol is stratigraphically correlated with the Vytachiv soil (according to the classification cited in Gozhik et al., 1995) in the Kurortne (in some papers known as Prymorske) section. Recent luminescence dating has shown that this double palaeosol S2 corresponds to MIS 7 (not MIS 3 as previously thought) and the MS profile from the Kurortne (Prymorske) section (Nawrocki et al., 1999 ) is almost identical with the one measured in the Costineşti section (Necula et al., 2015), $250 \mathrm{~km}$ SW of Kurortne. However, in the Kurortne and loess sections of Romania, MS values of the S2 soil are far from highest among other palaeosol units, having a characteristic double peak, which is not clearly evident in the R-S2 soil at Roksolany. The highest values of MS in most sections of the Danube Basin are in the next lower soil S3, assigned to MIS 9 (Marković et al., 2015; Necula et al., 2015). A probable solution could be consideration of absolute values of the MS, not relative maxima. Since differences in palaeoclimate between the Roksolany and Dobrogea sections are unlikely due to the close proximity, similar absolute values of the MS should be observed. The MS of the S2 unit in neighbouring Romanian sections reaches the same $80-100 \times 10^{-8} \mathrm{~m}^{3} \mathrm{~kg}^{-1}$, although the lower S3 unit shows $\sim 120-150 \times 10^{-8} \mathrm{~m}^{3} \mathrm{~kg}^{-1}$ (Necula et al., 2015).

Thus, we correlate the upper dominant two MS peaks in the R-S2 pedocomplex with MIS substages $7 \mathrm{a}-\mathrm{c}$ and the $\mathrm{pt}_{\mathrm{b} 2}$ subunit from Vyazivok, and the lower weaker peak with MIS 7e and the $\mathrm{pt}_{\mathrm{b} 1}$ subunit. In Ukrainian loess sequences located north of Roksolany, the Potyagaylivka palaeosol is not characterized by expressive rubification, but the succession of red-brown palaeosols in the southern Danube loess sequences, due to progressive termination of Mediterranean influence, ended exactly during MIS 7, corresponding to soil S2 (Obreht et al., 2016). The underlying well-developed loess R-L3 we correlate with MIS 8 and with the Oril unit.

Let us take a closer look again at the R-S3 soil complex. $\mathrm{R}-\mathrm{S} 3$ is a specific Roksolany triple pedocomplex, which contains the reddish-brown R-S3S1 soil and double grey-brown rubified palaeosol complex composed of the R-S3S2 and 


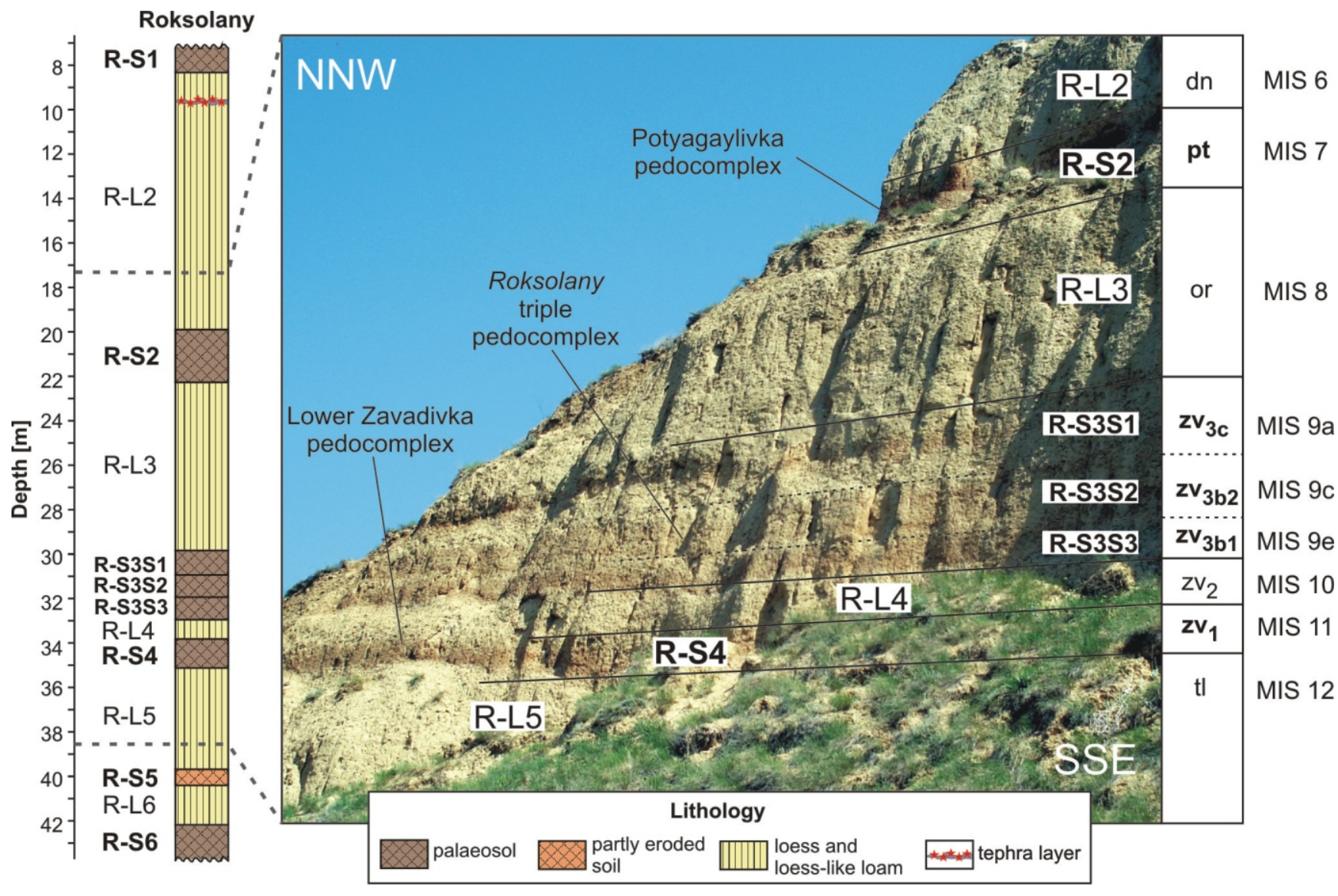

Fig. 10. Field photograph and proposed chronostratigraphic subdivision of middle units of the Roksolany section

R-S3S3 soils (Fig. 10), and described previously by Gozhik et al. (2000, 2007), Bogucki et al. (2013) and Łanczont et al. (2015) as the Pryluky unit (MIS 5). In the interpretation of Tsatskin et al. (1998, 2001), it contains discrete partly eroded palaeosols (corresponding to MIS 17-19) interbedded with thin loess layers. According to our field recordings, the description in Bogucki et al. (2013) and comment of Zh. Matviishyna (personal communication, 2014), the upper three palaeosols, i.e. R-S3S1, R-S3S2 and R-S3S3, are separated by calcareous loams of light fawn colour, representing Bca horizons of their top soils, not loess layers. Consequently, these pedological features on their own suggest the Roksolany triple unit as a single well-developed pedocomplex R-S3, in contrast to the previous interpretation of Tsatskin et al. $(1998,2001)$ of two separate pedocomplexes. It seems that these authors were forced to allocate more interglacials above the higher position of the MBB in the R-L4 loess.

The lower well-developed red-brown palaeosol R-S4 (Kaydaky unit, MIS 7 in Gozhik et al., 2000; Bogucki et al., 2013 and Łanczont et al., 2015; or $\mathrm{PK}_{7}$ pedocomplex, MIS 21 in Tsatskin et al., 2001) is darker in colour due to abundant Mn mottles. It is separated from the R-S3 pedocomplex by the 1.0 $m$ thick loess layer R-L4. High MS values and the sharp form of MS structure in the upper part of R-S4 are very similar to those in the V-S4 unit from Vyazivok, as well as to the marine record of MIS 11 (Fig. 3). The upper dominant peak in R-S4 is securely correlated with the $\mathrm{zV}_{1 \mathrm{~b} 2}$ subunit at Vyazivok and with MIS 11c. Furthermore, three separate peaks corresponding to R-S3S1, R-S3S2 and R-S3S3 are identical to three specific peaks in the well-developed V-S3 palaeosol complex (subunits $z v_{3 c}, z_{3 b 2}$ and $z v_{3 \mathrm{~b} 1}$, respectively), and are even more similar to the ODP curve of substages $9 a, 9 c$ and 9 e. The marine substages $9 a$ and $9 \mathrm{c}-\mathrm{e}$ in the benthic $\delta^{18} \mathrm{O}$ record are separated in the same way as the MS peak of the R-S3S1 soil $\left(\mathrm{zv}_{3 \mathrm{c}}\right)$ is offset from bimodal peak of the double palaeosol R-S3S2-R-S3S3 $\left(\mathrm{zv}_{3 b}\right)$. At Roksolany, the R-S3S1 soil $\left(\mathrm{zv}_{3 \mathrm{c}}\right)$ has a thick Bca horizon just like the $\mathrm{zv}_{3 c}$ soil in the Vyazivok section. Thus, we correlate the welded pedocomplex R-S3 with MIS 9 and the Upper Zavadivka unit $\left(\mathrm{zv}_{3}\right)$, and the lower well-developed pedocomplex R-S4 with MIS 11 and the Lower Zavadivka unit $\left(\mathrm{ZV}_{1}\right)$. The uppermost subunit R-S3S1 may be considered as an interstadial soil because it corresponds to the less warm event at MIS 9a in the benthic $\delta^{18} \mathrm{O}$ record (Fig. 3). Previously, Gozhik et al. (2007), based on meadow steppe pollen spectra, also considered that the upper R-S3S1 soil should be related to interstadial conditions (namely of the Amersfoort/Brørup interstadial).

According to the palynological analysis of Gozhik et al. (2007), loess of the R-L4 unit was formed under specific cold and arid climatic conditions with spread of the steppe vegetation, and was attributed by Gozhik et al. (2000), Bogucki et al. (2013) and Łanczont et al. (2015) to the MIS 6 (Tyasmyn) glacial. We correlate R-L4 with the strong glacial MIS 10 corresponding to the Middle Zavadivka $\left(\mathrm{Zv}_{2}\right)$ stage, which also represents cool arid conditions in Ukrainian loess according to the palynological data of Arap and Vozgrin (1989, cited in Gozhik and Gerasimenko, 2011), Gerasimenko and Matvijishyna (2007), and Matviishyna et al. (2010).

These arguments lead us to an important conclusion. The Middle Zavadivka stratigraphic unit $\mathrm{zv}_{2}$ is poorly represented in 
the Ukrainian loess succession and does not yet have a sufficient holostratotype. In most complete sequences with Zavadivka soils in central Ukraine and Transcarpathia, it corresponds to a thin cryogenesis level within the welded $z v_{1}-z v_{3}$ pedocomplex (Matviishyna et al., 2010). Since the latter looks like a single palaeosol, most Quaternary studies in Ukraine suggest that the Zavadivka superunit should be compared with only one interglacial (MIS 11 or MIS 9, see Table 2). Gerasimenko and Matvijishyna (2007), based on pollen spectra of cold steppe type and evidence of strong cryoturbation, deeply deforming the lower $z v_{1}$ soils, concluded that the loess/loam unit $z v_{2}$ within the Zavadivka soils had a glacial origin. In addition, the upper part of the Lower Zavadivka soil unit $\mathrm{zv}_{1}$ in the Pleistocene succession of western Ukraine is associated with the last appearance of Pterocarya, which is considered to have disappeared in Europe after MIS 11 (Gerasimenko and Matviishyna, 2007). The identification of a relatively thick $(1.0 \mathrm{~m}) \mathrm{R}$-L4 loess, as an equivalent of the Middle Zavadivka unit corresponding to MIS 10 , allows us to consider the Roksolany sequence as a Ukrainian lectostratotype of the $z v_{2}$ loess. This loess is distributed across the entire Lower Dniester Basin area (Tsatskin et al., 2001; Gozhik, 2013).

The MBB in the Roksolany section is located between two welded soil units: R-S7 and R-S8 (i.e. Lubny and Martonosha after Gozhik et al., 2007 and Bogucki et al., 2013). The R-S7 unit has a complex structure and consists of an upper brown and lower red-brown soil. The R-S7 palaeosol in the exposure studied R6 (Fig. 4B) is reduced, and the R-L8 loess is wedged out, but the latter may correspond to a thin light-coloured layer visible several meters south and north of the exposure; moreover, the R-S7 palaeosol seems most developed (Fig. 4C). In all previous studies (Gozhik et al., 2007; Bogucki et al., 2013 and others), no loess unit between the Lubny and Martonosha palaeosols was described. In our exposure, the cleaning of a thin (a few cm) light layer between the R-S7 and R-S8 soils left a completely reddish loam of the upper soil. The contact between the R-S7 and R-S8 palaeosols is very distinct, which also may indicate erosional incision. Moreover, unlike the long Matyama-Brunhes transition zone within the thick V-S7 pedocomlex at Vyazivok (Fig. 8), the transition zone in the Roksolany section looks like a sudden reversal (Fig. 7). The entire well-developed R-S8 complex is characterized by reversed polarity, so the polarity transition zone of the MBB most likely belongs within the truncated R-S7 pedocomplex. According to our field observations, a high content of clay is immediately obvious in the R-S7 pedocomplex, identical to the same feature in the brown and red-brown clayey V-S7 (Shyrokyne) soils in the Vyazivok section. Taking all this into account we correlate the R-S7 unit with the V-S7 complex at Vyazivok, i.e. the Shyrokyne unit, and with MIS 19.

In the Ukrainian subaerial succession, the Illichivsk unit (equivalent of R-L8), unlike the thick Berezan, Pryazovya and Sula loess, is represented by a thin $(0.2-1 \mathrm{~m})$ loess and loess-like loams (Gozhik and Gerasimenko, 2011). In all the best developed Danube loess sequences (see overview, for example, in Marković et al., 2011, 2012, 2015; Sümegi et al., 2018), two soil complexes S7 and S8 (representing MIS 19 and MIS 21 , respectively) are separated by the equally thin loess layer L8 corresponding to MIS 20, while loess units L9, L7 and L6 are characterized by much greater thickness.

The R-S7 pedocomplex is topped by loess layer R-L7 which we correlate with MIS 18, and with the Pryazovya stratigraphic unit.

Consequently, the overlying well-developed reddish-brown soil complex R-S6 (Zavadivka after Gozhik et al., 2007 and Bogucki et al., 2013) is rightfully correlated with MIS 17 and, therefore, with the V-S6 (Martonosha) unit at Vyazivok. According to the data of Gozhik et al. (2007), the palynological features in the R-S6 palaeosol can be also compared to the environment of the Martonosha period. The pedocomplex consists of two (Gozhik et al., 2007) or three (Bogucki et al., 2013) subunits. Our field observations clearly suggest the presence of two soils: an upper thick R-S6S1 soil and a lower thinner R-S6S2 soil. However, three separate "cascades" of the MS curve are revealed with high values in the middle levels (base of the R-S6S1 soil), which are similar to those of the marine isotope record in substages 17a, 17c and 17e (Fig. 3). In the Black Sea Lowland, the Martonosha unit is represented by three soils of the early optimum $\mathrm{mr}_{\mathrm{b} 1}$, late optimum $\mathrm{mr}_{\mathrm{b} 2}$ and final pedogenesis phase $\mathrm{mr}_{\mathrm{c}}$ (Sirenko, 2017).

Within the R-L6 loess and uppermost $0.25 \mathrm{~m}$ of the R-S6S1 soil a reversed polarity zone corresponds to a Stage 17 excursion (670 ka; Table 3), which has been found also in the Udvari U2-A borehole (above the U2-S6 soil; Sümegi et al., 2018) and Stari Slankamen section (above the V-S6 soil; Hambach et al., 2009; Marković et al., 2011; Marković et al., 2015). In all three sections this magnetozone is located below a characteristic marker, a weakly developed soil (R-S5, U2-S5, V-L6S1, respectively; see Figure 11). Therefore, we correlate the R-L6 loess with MIS 16 and with the Sula unit.

A weak reddish-brown palaeosol R-S5 at $\sim 40 \mathrm{~m}$ depth has relatively significant peak values of MS $\left(40-50 \times 10^{-8} \mathrm{~m}^{3} \mathrm{~kg}^{-1}\right)$. In the interpretation of Gozhik et al. (2007) and Bogucki et al. (2013), this is an eroded palaeosol (Potyagaylivka, MIS 9) with an incomplete soil profile. The contact between the R-S5 soil and overlying R-L5 loess is jagged, erosional; the A horizon is $0.2 \mathrm{~m}$ thick (Bogucki et al., 2013). According to the pedostratigraphy proposed by Tsatskin et al. (1998, 2001), R-S5 should be an incipient soil, formed during MIS 23. Taking into account high values of MS and the pedological data, we regard the R-S5 soil as a partly eroded palaeosol correlating with an interglacial event.

In view of the new chronostratigraphic interpretation of the Serbian loess-palaeosol sequence proposed by Sümegi et al. (2018), the weak soil V-L6S1 in Vojvodina sections should correspond to MIS 13-15, and the well-developed rubified palaeosol V-S5 above to the warmer MIS 11. Therefore, V-S3 and V-S4 in Serbia are considered as a welded pedocomplex correlating with MIS 9. The V-L6S1 unit in Vojvodina is an obvious stratigraphic equivalent of R-S5 at Roksolany, not only by pedological description, but also according to magnetostratigraphic data. Futhermore, the specific MS pattern of the R-S4 soil at Roksolany is strikingly similar not only to that of the MIS 11 palaeosol units V-S4 at Vyazivok (Fig. 3) and Phe1-MB1-2 in the Paks section (Sartori, 2000: 83; Sümegi et al., 2018: fig. 6), but replicates the same MS structures of the coeval V-S5 soil unit in the Titel-Stari Slankamen composite loess-palaeosol sequence (Song et al., 2018: fig. 3). In the nearest Kurortne (Prymorske) section, the Kaydaky pedocomplex after Gozhik et al. (1995), a stratigraphic equivalent of the R-S4 soil with similar lithopedological features, based on MS pattern (Nawrocki et al., 1999), has been correlated by Necula et al. (2015: fig. 10) with the Romanian S4 soil and similarly with MIS 11. In the Paks section, the palaeosol unit corresponding to MIS 13-15, marked by a pedocomplex of sandy (Hs1) soil overlain by hydromorphic soils (Mtp1-2) and topped by a forest soil (Phe2; see decription in Sartori (2000), Sümegi et al. (2018) and references therein), has similar features to the V-S5 soil at Vyazivok that we correlate with MIS 13-15. Likewise, the MS of this pedocomplex at Paks is similar to the one measured in the R-S5 unit at Roksolany $\left(40-50 \times 10^{-8} \mathrm{~m}^{3} \mathrm{~kg}^{-1}\right)$. Thus, taking into account the characteristic MS pattern of the 


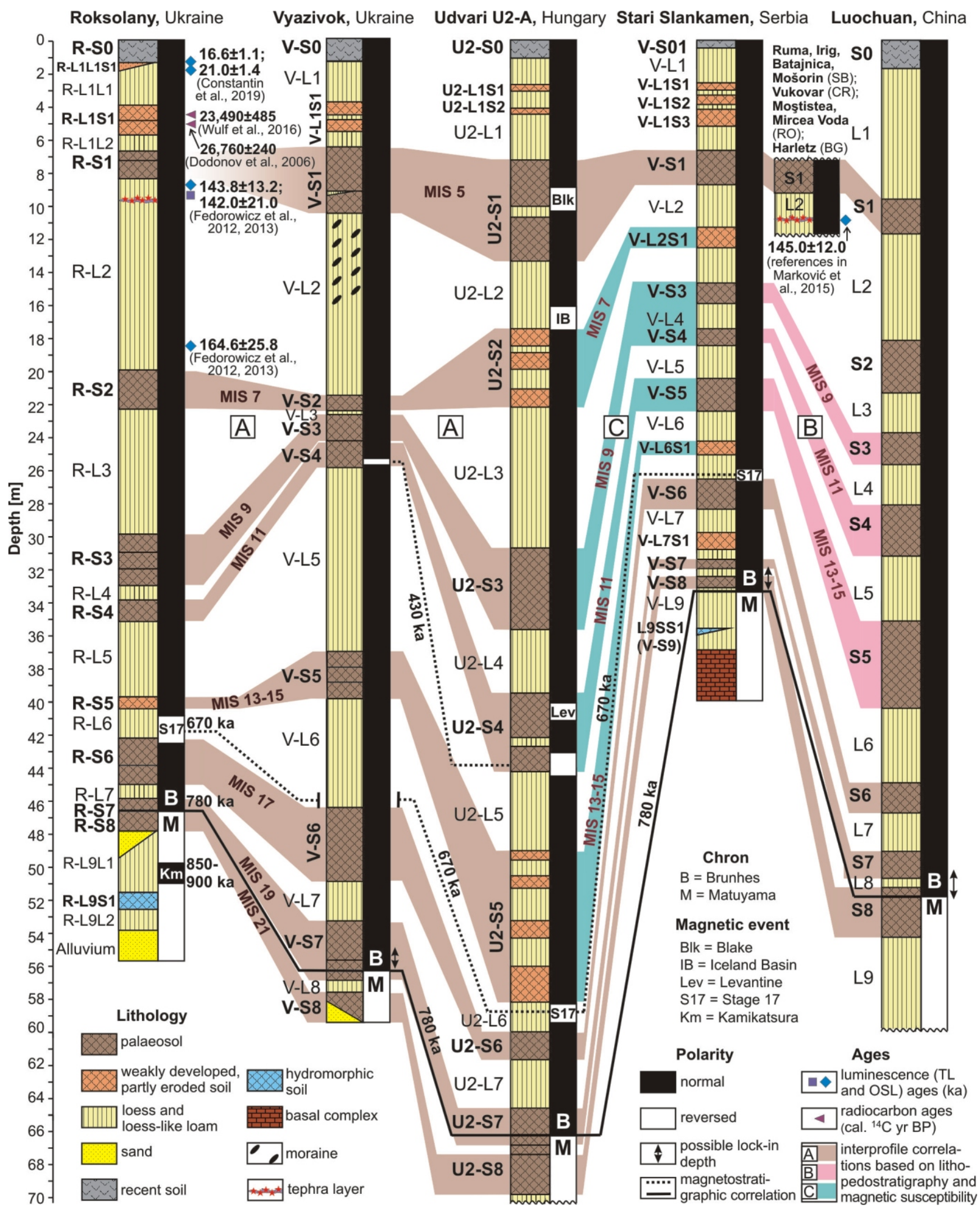

Fig. 11. Correlation chart of the sequences studied at Roksolany and Vyazivok and the most representative loess-palaeosol sections of the Danube Basin and CLP (with simplified lithostratigraphy) resulting from palaeomagnetic and magnetic susceptibility records

The magnetic polarity zonation of the Udvari U2-A sequence is from P. Márton (1998, fide Sümegi et al., 2018), Stari Slankamen from Marković et al. (2011) and Song et al. (2018), and Luochuan from Jin and Liu (2010, fide Liu et al., 2015). A - correlations proposed by this study, and common anchor to MIS in the chronostratigraphic models of Marković et al. (2015) and Sümegi et al. (2018) for Serbian sequences; B - direct correlations between Stari Slankamen and Luochuan loess-palaeosol sequences according to Marković et al. (2015); C - alternative correlations proposed by Sümegi et al. (2018). Luminescence and radiocarbon dates for the Roksolany section accepted in this study are shown. For other ages see Figure 9 and explanation in the text. Schematic inset of stratigraphic position of the L2 Tephra in loess sections listed from Serbia (SB), Croatia (CR), Romania (RO) and Bulgaria (BG) is shown to the right of the column of Stari Slankamen 
R-S3 (MIS 9), R-S4 (MIS 11) and R-S6 (MIS 17) palaeosols at Roksolany and corresponding units in key European loess profiles, we correlate, with high confidence, the R-S5 unit with V-S5 at Vyazivok, and, therefore, with MIS 13-15. The implication is that the R-S5 palaeosol links to the Lubny stratigraphic unit.

Consequently, the overlying thick loess R-L5 perfectly correlates with the analogous thick loess bed of the V-L5 unit at Vyazivok, and corresponds to the cold arid Tyligul stage (Matviishyna et al., 2010; Sirenko, 2019) related to the very strong glacial MIS 12 .

Returning to the lowermost part of Roksolany, the R-S8 unit (Martonosha soil after Gozhik et al., 2007 and Bogucki et al., 2013) below the MBB is securely correlated with MIS 21. It has a distinctive MS pattern of three peaks, similar to structures of the benthic $\delta^{18} \mathrm{O}$ record during MIS 21 (substages 21a, 21c, and combined into one group 21e-g; Fig. 3), most likely corresponding to final pedogenesis phase $\mathrm{kr}_{\mathrm{c}}$, late optimum $\mathrm{kr}_{\mathrm{b} 2}$ and early optimum $\mathrm{kr}_{\mathrm{b} 1}$ of the Kryzhanivka pedogenesis period. As regards palaeopedological features, the R-S8 pedocomplex is expressed brownish-red sandy soil, very reminiscent to the V-S8 (Kryzhanivka) brownish-red sandy soil at Vyazivok.

In exposure R6 (Fig. 4), the R-S8 palaeosol is underlain by greenish-grey sands. In exposure R7 (south of R6), thick (up to $4 \mathrm{~m}$ ) loess R-L9L1 is observed below the R-S8 pedocomplex. In the lower part of this, the Kamikatsura excursion ( 850-900 ka) has been identified (Table 3), which is associated with MIS 22. The lowermost hydromorphic R-L9S1 soil is characterized by low magnetic enhancement $\left(15 \times 10^{-8} \mathrm{~m}^{3} \mathrm{~kg}^{-1}\right)$. Based on a corresponding weak peak in the LR04 stack record (Lisiecki and Raymo, 2005), we correlate the R-L9S1 unit with MIS 23. Therefore, the R-L9L2 unit represented by sandy clay loam correlates with MIS 24 . The above stratigraphic model is strikingly similar to the typical loess-palaeosol sequence seen on the central and southern CLP, as represented by the classic Luochuan section, and also in Serbia (e.g., Stari Slankamen) (Fig. 11). The hydromorphic soil R-L9S1 corresponds to the Chinese and Serbian weakly developed soil L9SS1 (Song et al. 2018), intercalated in the thickest loess unit below the MBB, the L9. The above adjustment is consistent with the marine evidence showing that MIS 23 was most likely an interstadial climatic event, which occurred between the longer glacial stages of MIS 24 and MIS 22 (Song et al., 2018).

In the loess-palaeosol sequence of Ukraine, the thickest loess unit below the Matuyama-Brunhes reversal is the Berezan unit, composed of subaerial, alluvial, and lacustrine-alluvial deposits. Its main features are a large thickness $(1-10 \mathrm{~m})$, three different-coloured layers $\left(\mathrm{br}_{1}, \mathrm{br}_{2}, \mathrm{br}_{3}\right)$ and the occurrence of hydromorphic (embryonic) soils. The lower subunit, $b r_{1}$, is represented by loess-like loams and clays. The upper subunit, $\mathrm{br}_{3}$, is a loess, marked by a lower clay content and xeric vegetation. In the middle part of the Berezan unit, the palaeosol $\mathrm{br}_{2}$ occurs, which is represented by a specific thin ( $0.5 \mathrm{~m}$ thick) reddish-brown soil in the south and by a gleyic cambisol in the north (Matviishyna et al., 2010; Gozhik and Gerasimenko, 2011).

In the Kryzhanivka section ( $50 \mathrm{~km}$ north of Roksolany), a familiar pattern can be observed. Tretyak et al. (1987) found the MBB lay in the Shyrokyne unit. In the mid-part of the $10 \mathrm{~m}$ thick Berezan unit a thin $(1.0 \mathrm{~m})$ normal polarity zone (overlying the $0.4 \mathrm{~m}$ thick red-brown clay layer $\mathrm{br}_{2}$ ) was interpreted as the Jaramillo event (former age 900-960 ka). At the present stage of knowledge, it is evident that this zone is not related to the Jaramillo subchron (0.99-1.07 Ma ago; Laj and Channell, 2007), which should represent two or three palaeosols (MIS 31, MIS 29 and possibly the interglacial peak within MIS 28, Head and Gibbard, 2015). Apparently, it was the Kamikatsura excur- sion. In the Beregove section ( $30 \mathrm{~km}$ north of Sevastopol), the Gauss-Matuyama reversal (2.58 Ma) was detected in the Kyzyl-Yar (kz) unit (Tretyak et al., 1987). Also, a few zones of normal polarity within the Matuyama chron were identified (but not named). In our interpretation, the Jaramillo subchron should be related to a long uppermost normal-polarity zone in the lower part of the Beregove palaeosol complex (bv; below the Berezan unit) and upper part of the Siversk clay/palaeosol suite (sv; topped by the Beregove complex). Moreover, the Berezan unit at Beregove is characterized by reversed polarity. In view of the above, we propose to correlate the R-L9 unit (MIS 22-24) at Roksolany with the Berezan unit.

These correlations support the estimated age of the basal alluvium deposits underlying the R-L9 loess. Micromammal fauna of alluvium at Roksolany belongs to the end of the Nogaysk stage of Taman complex (Gozhik et al., 2007), supported by benchmark fossil rodent data: Allophaiomys pliocaenicus, Prolagurus pannonicus, the genus Mimomys. Also fossils of large mammals were found: Archidiscodon meridionalis tamanensis Dubrovo and Dicerorhinus etruscus Falconer. At various localities of the Black Sea northern coast, these index fossils are related to MIS 21-25 (Kolfschoten and Markova, 2005 and references therein), definitely younger than the Jaramillo reversal (Kolfschoten and Markova, 2005; Gozhik et al., 2007; Krokhmal, 2009), but not younger than the base of the red-brown clayey soil complex overlying the Berezan deposits, namely, in the interpretation of Krokhmal (2009), the Shyrokyne unit including that in the Kryzhanivka section. We follow the original description of the Kryzhanivka stratotype section made by Veklich (1968) and repeated in Tretyak et al. (1987, 1989): the Berezan loams are topped by the Kryzhanivka palaeosol, red-brown in colour, $1.6 \mathrm{~m}$ thick, and, in our opinion, naturally matching with MIS 21 . Therefore, the age of alluvium deposits at Roksolany is limited by the chronological framework of MIS 25 according to fossil data and our magnetostratigraphic interpretation. Hence, we can state that the development of Nogaysk fauna at Roksolany occurred after $960 \mathrm{ka}$ ago and corresponds to the Late Beregove period ( $\left.\mathrm{bv}_{3}\right)$. According to Veklich (1968), subaerial deposits of the Berezan and Beregove units are equivalents of alluvium of the IX terrace.

Based on the revised chronology, age-depth and sedimentation rate models were constructed for the Roksolany sequence (Fig. 12). Obviously, age-depth/SR models according to the chronostratigraphy of Gozhik et al. (2000) and Tsatskin et al. (2001) differ drastically. Our model seems more realistic: a small deviation of the age-depth curve is observed; the average sedimentation rate is $8.9 \mathrm{~cm} / \mathrm{ky}$ for loess and $4.5 \mathrm{~cm} / \mathrm{ky}$ for palaeosols, which is typical for loess sequences in the Danube Basin (Buggle et al., 2009; Marković et al., 2012, 2015; Sümegi et al., 2018). The R-L3 loess (MIS 8 ) is characterized by the highest accumulation rates $(20.8 \mathrm{~cm} / \mathrm{ky})$ in the section, just like the MIS 8 loess V-L3 in the composite Serbian loess-palaeosol sequence (14.8 cm/ky; Marković et al., 2012).

REFINED CHRONOLOGY OF UKRAINIAN PEDOSTRATIGRAPHY AND ITS INTEGRATION INTO THE PAN-EURASIAN CORRELATION SCHEME

Based on the newly established chronostratigraphy for Roksolany and Vyazivok, in Figure 11 we present an interprofile stratigraphic correlation between the two sequences studied and the most representative loess sections in the Middle Danube Basin (Udvari-U2, Stari Slankamen) and the CLP (Louchuan). To correlate the loess-palaeosol sequences we have used magnetostratigraphic markers, MS curves, and in part pedological and palaeoenvironmental data, discussed above. 


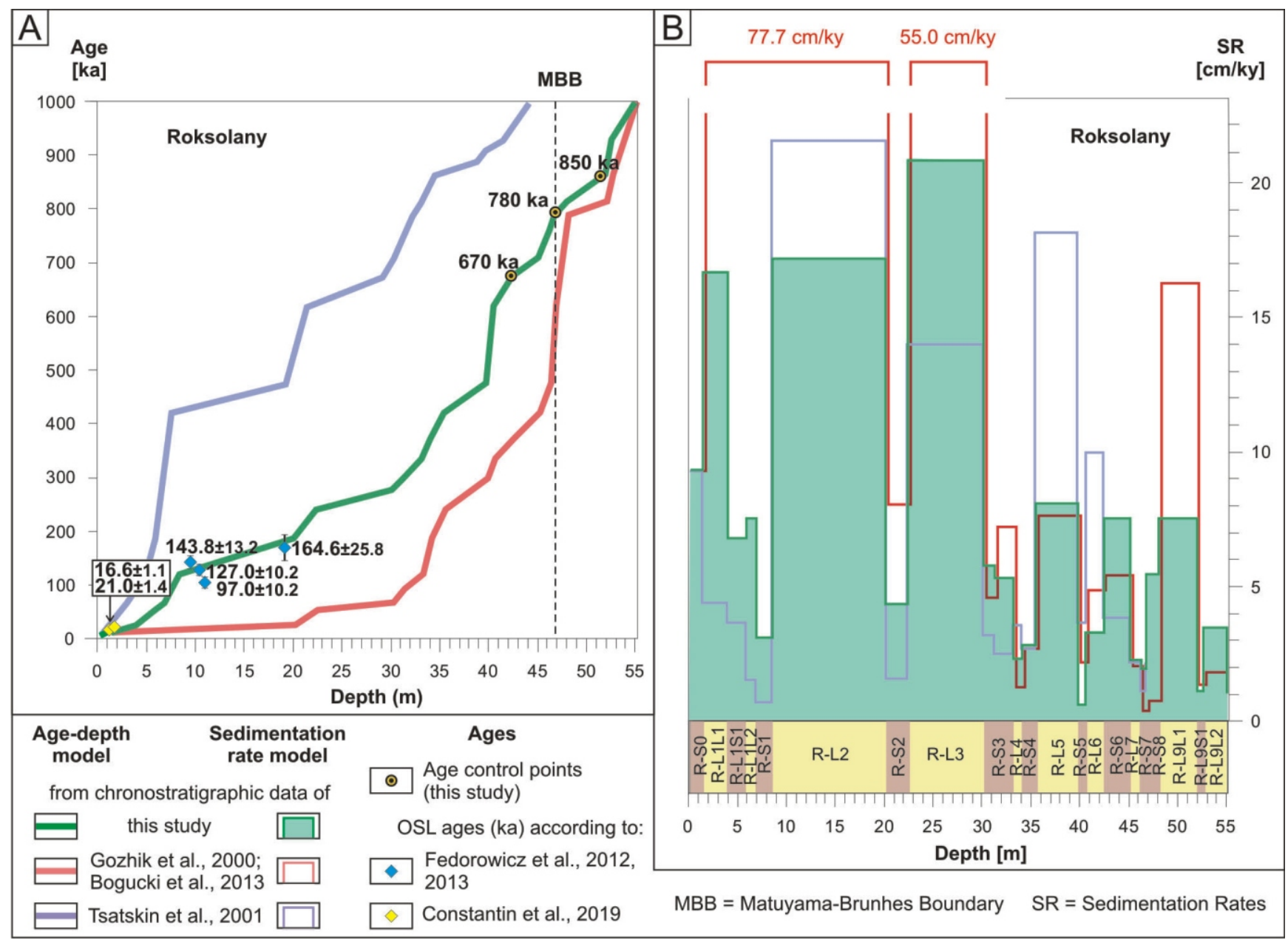

Fig. 12. Age-depth models for the Roksolany section (A) and calculated sedimentation rates (B) according to: our data (green); Tsatskin et al. (2001, blue); Gozhik et al. (2000) and Bogucki et al. (2013, red)

Sedimentation rates are shown as a function of depth to compare values for the same units in the chronostratigraphic models considered

The proposed age interpretations of the Roksolany and Vyazivok sections, outlined above with reference to other loess-palaeosol sequences in the Danube Basin and CLP, allows for the development of a unified pan-Eurasian regional stratigraphic chart. In Table 4 we have made a correlation between the Stratigraphic Framework of the Quaternary deposits of Ukraine (Veklich et al., 1993, modified by Gozhyk, 2012), two dominant schemes in the Middle Danube Basin (Marković et al., 2011, 2015 and Sümegi et al., 2018), CLP (Kukla, 1987), and the marine isotope record (Shackleton et al., 1990; Lisiecki and Raymo, 2005). For stratigraphic equivalents of palaeogeographic stages we have adopted a designation in the system of Marković et al. $(2011,2015)$ by adding the prefix $\mathbf{U}$ indicating Ukrainian loess stratigraphy. A comparison of magnetic susceptibility, palaeomagnetic results (our data and materials of Tretyak and Vigilyanskaya, 1994), climatic conditions (Veklich, 1982, 1987; Lisiecki and Raymo, 2005; Matviishyna et al., 2010; Gozhik and Gerasimenko, 2011; Fitzsimmons et al., 2012; Head and Gibbard, 2015; Obreht et al., 2016; Sirenko, 2017, 2019; Sümegi et al., 2019), palaeopedological properties (Veklich, 1968; Sirenko and Turlo, 1986; Marković et al., 2012; Sümegi et al., 2018 and others), as well as analysis of accumulation rates, has led us to the following interpretation.
The stratigraphic unit U-S9 (Beregove warm palaeogeographic stage; Table 4), represented by red soils and red-brown clays in large areas of southern, central and eastern Ukraine, is correlated with basal red soils/red clays in the Danube Basin. The Beregove stage terminated $\sim 940 \mathrm{ka}$, i.e. at the end of MIS 25. The typical configuration of the $100 \mathrm{ky}$ glacial cycles began at MIS 25, with higher glacial-interglacial contrasts, recorded in the subaerial sequence of Ukraine exactly after the Beregove stage.

The U-L9 loess unit (Berezan cold stage) is characterized by thick loess, loam and clay deposits, and is compared to the specific thick loess unit L9 in the Chinese and Danube sequences, correlating with MIS 22-24 (Fig. 11). Minor warming during MIS 23 was manifested by the embryonic soil U-L9S1 $\left(\mathrm{br}_{2}\right)$, identical to the weak palaeosol L9SS1 in Serbia and China. A harsh continental climate during the Late Berezan period $\left(\mathrm{br}_{3}\right)$ was related to global fluctuations in MIS 22 , caused by sudden ice-sheet growth.

The U-S8 soil unit (Kryzhanivka warm stage), expressed by rubified brown forest soils, is correlated with MIS 21. It corresponds to rubified forest palaeosols $\mathrm{H}-\mathrm{S} 8$ in the Hungarian and V-S8 in the Serbian composite pedostratigraphies. In the Kryzhanivka stage, humidity of climate and heat supply was 
consistently high. No separate glaciations are determined by pedological, palynological or MS data, - they all reflect only complexity of the single interglacial MIS 21 (substages 21a-g after Railsback et al., 2015).

The U-L8 loess unit corresponds to the Illichivsk cold stage, characterized by weak loess accumulation and less harsh subperiglacial environments, and is an equivalent of the thin loess L8 below the MBB in the Danube and Chinese sections, which corresponds to MIS 20. During MIS 20, summer insolation values at $65^{\circ} \mathrm{N}$ were relatively high for a glacial cycle. Even so, MIS 20 represents a severe if short-lived glacial event (Head and Gibbard, 2015).

The U-S7 soil unit (Shyrokyne warm stage) is represented by thick brown (brunizems in the north, cambisols in the south; $\mathrm{Sh}_{3}, \mathrm{U}-\mathrm{S} 7 \mathrm{~S} 1$ in this study) and red-brown soils (transitional to chromic cambisols, luvisols; sh 1 (U-S7S2), and a rarely observed thin clayey layer $\left(\mathrm{sh}_{2} / \mathrm{U}-\mathrm{S} 7 \mathrm{~L} 1\right)$ in-between. We correlate the U-S7 unit with the well-developed MIS 19 palaeosol complex S7 in the Middle Danube Basin and CLP. The Matuyama-Brunhes reversal belongs to the lower subunit U-S7S2 $\left(\mathrm{sh}_{1}\right)$. Insignificant fall of temperature and aridization occurred in the Middle Shyrokyne period $\left(\mathrm{sh}_{2}\right)$, marked by a reduction of thermophilic broad-leaved trees and expansion of herbaceous groups; we do not associate this with a glaciation A markedly bimodal peak in MIS 19 with drier and cooler conditions for the intervening interval (MIS 19b) is registered in many reference marine successions of the world (for a comprehensive review, see Head and Gibbard, 2015; Nomade et al., 2019). According to the palaeopedological studies of loess-palaeosol sequences of Ukraine (Sirenko and Turlo, 1986; Gozhik and Gerasimenko, 2011), the climatic optimum of the Shyrokyne stage corresponds to the $\mathrm{sh}_{1}$ substage with the maximum temperatures during the late $\mathrm{sh}_{1 \mathrm{~b} 2}$ phase and the maximum humidity during the early $\mathrm{sh}_{1 \mathrm{~b} 1}$ phase. The main expansion of warm forest during the $\mathrm{sh}_{1}$ period, dominated by broad-leaved trees, naturally correlates to climatic optimum MIS 19c (interglacial sensu-stricto). However, in more recent palynological studies (e.g., Sirenko, 2017), the Late Shyrokyne substage $\mathrm{Sh}_{3}$ is considered as another climatic optimum. In our view, the $\mathrm{sh}_{3}$ soils characterize the final phase of the Shyrokyne pedogenesis period (post-optimal climate oscillation). A warmtemperate climate during the $\mathrm{sh}_{3}$ substage, represented by soils with lower weathering indices, formed under steppe in the south and forest-steppe in the north, indicate mild interstadial conditions most likely related to the MIS 19a interval. A correlation of the U-S7S1 subunit with the interstadial MIS 18b-d soil L7SS1 (V-L7S1) observed in numerous Chinese and Danube loess-palaeosol sections (Marković et al., 2015, Song et al., 2018 and others) also cannot be excluded. Therefore, the vegetation character of the upper interim horizon of the U-S7 soil unit reflects a peculiar continuous MIS 19a/MIS 18 climatic transition. Veklich (1973, fide Tretyak and Volok, 1976), based on palaeopedogenesis constructions, had precisely predicted the age of the Shyrokyne stage (pedogenesis palaeorhythm after M. Veklich) as $\sim 750 \mathrm{ka}$; nonetheless, later Veklich $(1987,1995)$ revised his own estimates.

Loess deposits of the U-L7 unit (Pryazovya cold stage, MIS 18 ) in all Ukrainian sections are characterized by normal polarity and included into the Brunhes chron.

The U-S6 soil unit (Martonosha warm stage), represented by brown forest soils, rubified in southern and central Ukraine, is associated with MIS 17 and corresponds to the S6 palaeosol with the same pedological features in the Danube Basin. No periglacial stage separating two hypothetical interglacials (MIS 17 and MIS 19) within the Martonosha period is revealed by palaeoclimatic studies: quite the opposite, the Middle Martonosha substage is characterized by warmer and more humid climatic conditions than the Late Martonosha substage or even the Lubny stage. In our opinion, the position of the MBB in Matonosha pedocomplex in some previous studies can be explained by methodological issues, random interpretation of palaeomagnetic data, controversial stratigraphic subdivisions, and stratigraphic incompleteness of the Martonosha and Shyrokyne units in several sequences. Notably, in the sequences with well-developed Martonosha and Shyrokyne palaeosol complexes, the MBB had been identified always in the lower Shyrokyne palaeosol. In addition, the reversed-polarity Stage 17 excursion on the roof of the Martonosha unit may had been confused in some studies with the Matuyama chron. The Matuyama-Brunhes reversal could not occur at the end of the Martonosha stage (i.e. at the end of MIS 17) as proposed in many Quaternary studies.

The U-L6 loess unit, related to the Sula cold stage and marked by the first periglacial landscapes in Ukraine, is associated with the strong glacial MIS 16.

The Lubny warm stage in the loess-palaeosol succession of Ukraine corresponds to the U-S5 soil unit, and is characterized by a more temperate climate than in previous interglaciations; moreover, the final substages point to even colder climatic conditions. We correlate the Lubny stage with MIS 13-15, as in all prevalent chronostratigraphic models of Ukraine. In the central loess-steppe zone it is represented by 3-4 chernozem-like, meadow, brown, grey forest, loessified and hydromorphic/gleyed soils (Table 4). Similar pedological features are characteristic of the H-S5 pedocompex (MIS 13-15) in the Hungarian loess sequence. In the western Black Sea region, the pedostratigraphic position of the U-S5 (Lubny) unit should be revised following the proposed stratigraphy for the Roksolany sequence.

In the wider Asian region, several studies based on terrestrial and marine records indicate intense interglacials during MIS 15 and MIS 13, with a relatively warm MIS 14 glacial between, while other regions (e.g., the North Atlantic Ocean) present weak warming (Matsuzaki et al. 2014 and references therein). The Asian region intense warming during this interval was associated with a strong East Asian Monsoon. No monsoon forcing is expected in central and southeastern Europe, and the mechanism of hypothetical intense warming comparable to that in Asia is not determined (Zeeden et al., 2018). In contrast to MIS 15 and especially to MIS 11 , MIS 13 is routinely the coolest interglacial of the past $800 \mathrm{ky}$ in various long palaeoenvironmental records from around the world. MIS 13 is characterized by lower greenhouse gas $\left(\mathrm{CO}_{2}, \mathrm{CH}_{4}\right)$ concentrations, cool Antarctic temperatures and high benthic $\delta^{18} \mathrm{O}$ values related to higher global ice-volume and/or colder deep ocean temperatures (see references in Lisiecki and Raymo, 2005 and Sümegi et al., 2018). Therefore, the palaeoenvironmental pattern of the temperate Lubny stage of the loess-palaeosol development of Ukraine is in full agreement with global climatic variations.

The timing of the V-S5 soil unit (MIS 13-15 after Marković et al., 2011) in Serbian loess stratigraphy has been recently questioned by Sümegi et al. (2018), assigning the weak V-L6S1 soil to MIS 13-15, and the well-developed V-S5 to MIS 11. In our correlation scheme (Table 4) we share the latter suggestion also because of the obvious similarity of the Roksolany sequence to the Vojvodina loess-palaeosol sequence, as was shown above.

The U-L5 loess unit and its correlative, Tyligul cold stage, are characterized by distinct periglacial landscapes, more rapid loess accumulation, and reflect the coldest conditions in the Ukrainian loess archive 1.0-0.4 Ma. The U-L5 unit corresponds to the very strong MIS 12, associated with the return of large ice sheets.

The transition between MIS 12 and MIS 11 indicates an important global climatic shift: the Mid-Brunhes Event (Jansen et al., 1986) or the Mid-Brunhes Transition (Yin, 2013), which be- 
The theoretical pedostratigraphic column of the past $1 \mathrm{My}$ for loess-palaeosol formation of central and southern Ukraine, its relation to the Middle Danube and Chinese loess stratigraphy, and correlation with marine isotope stages

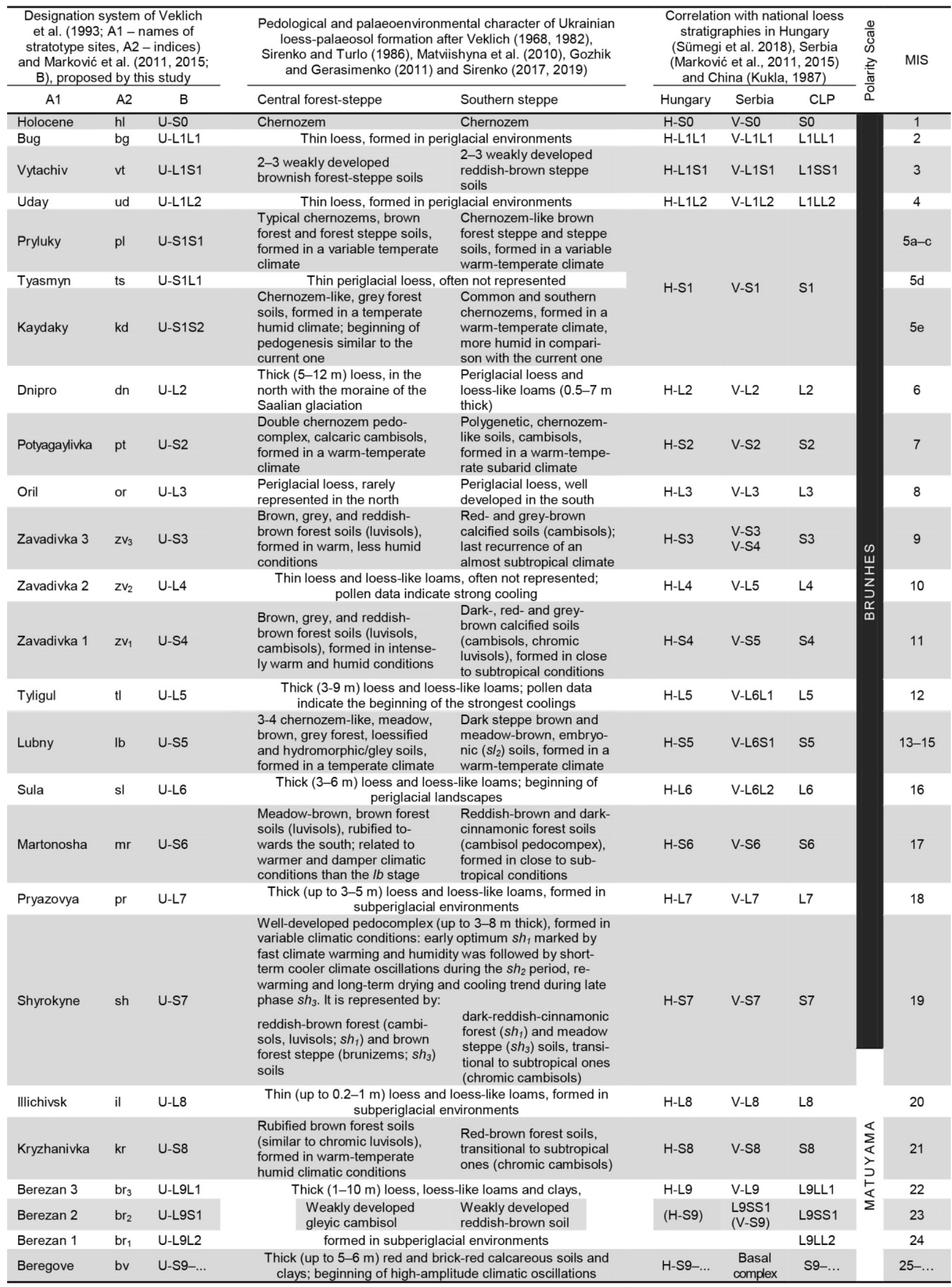


gan 430 ka with an increase in the amplitude of the $100 \mathrm{ky}$ climate cycles of the past $800 \mathrm{ky}$. The interglacials after $430 \mathrm{ka}$ were characterized by warmer climates and higher atmospheric concentrations of carbon dioxide than the interglacials before (Lisiecki and Raymo, 2005).

The intense warm climatic conditions during the Early Zavadivka (U-S4 soil unit, MIS 11) and Late Zavadivka (U-S3 soil unit, MIS 9) stages, represented by well-developed brown forest soils, are related to subtropical and near-substropical environments. The same palaeoclimatic and pedological features are typical of MIS 11 and MIS 9 soils in the Danube Basin. The Middle Zavadivka cold stage (U-L4 loess unit) indicates strong cooling and aridization, and undoubtedly corresponds to the separate glacial MIS 10 .

The U-L3 loess unit (Oril cold stage, MIS 8) is rarely represented in the north of Ukraine (eroded by glacial processes in Dnipro period), but is well developed in the south. The same pattern is well seen on the example of MIS 8 loess in the Vyazivok and Roksolany section (Figs. 3 and 11).

The U-S2 unit, corresponding to the Potyagaylivka warm stage, is well represented in southern Ukraine (polygenetic soil) and in the Dnieper Lowland (a pedocomplex of two chernozem-like soils). By pedological and magnetic susceptibility features it corresponds to the S2 pedocomplex in the Danube loess record, and is associated with MIS 7.

The glacial maximum of MIS 6 was the most extensive glaciation of the last 400 ky over Eurasia, the largest since MIS 12 (Colleoni et al., 2016). In Europe, MIS 6 is recorded by the largest ice advance of the Saalian stage correlated with the Dnieper glaciation in Ukraine. The Dnieper glaciogenic sequence is currently related to MIS 6 (Ehlers et al., 2013). In the Middle Dnieper area (the area of the former glacier tongue), a till of the corresponding U-L2 loess unit (Dnipro cold stage) is an important stratigraphic marker. Towards the south the U-L2 loess were formed under periglacial steppe conditions. They are characterized by larger thickness $(5-12 \mathrm{~m})$ due to proximity to the dust source from northern glaciated plains. TL/OSL dating in different sections provides numerical age frames for MIS 6 .

The U-S1S2 (Kaydaky) and U-S1S1 (Pryluky) units are correlated with MIS $5 \mathrm{e}$ and MIS $5 \mathrm{a}-\mathrm{c}$, respectively. The rarely observed thin loess corresponding to the U-S1L1 unit (Tyasmyn) is related to marine substage $5 \mathrm{~d}$ (the first Weichselian stadial). We pay attention here to the Vyazivok section, where high-resolution MS data revealed unprecedented completeness of the continental record of this period (Fig. 3). The pedological and palaeoenvironmental characteristics of MIS 5 chernozems in Ukraine are in full agreement with those in the Danube Basin.

The Uday (U-L1L2 unit, MIS 4) and Bug (U-L1L1 unit, MIS 2) cold stages were related to the end of the last glacial period. Weak warming during MIS 3 produced a complex of 2-3 interstadial brown soils of the U-L1S1 unit, corresponding to the Vytachiv warm stage. The same features are also observed in the southeastern European loess records during MIS 2-4.

\section{CONCLUSIONS}

Results of the magnetostratigraphic and palaeoclimatic studies of key loess-palaeosol sequences of Ukraine uncover fundamental contradictions in the stratigraphic reconstructions obtained by different authors in the last 50 years. Nowadays, magnetostratigraphy is the most reliable tool in establishing independent chronologies in loess-palaeosol archives reaching beyond $300 \mathrm{ka}$. Application of the palaeomagnetic method combined with the magnetic susceptibility record in the best de- veloped loess-palaeosol sequences of Ukraine have resulted in significant successes and allowed the following conclusions:

1. The Matuyama-Brunhes reversal, identified in the Roksolany and Vyazivok section in the lower part of palaeosol units R-S7 and V-S7, respectively, belongs to the same stratigraphic unit Shyrokyne (U-S7), and corresponds to the time equivalent of MIS 19. Unlikely many examples of the lower position of the MBB in loess layer L8 in Chinese and Danube sequences due to the lock-in depth effect, the MBB record at Roksolany and Vyazivok is not delayed or is insignificantly delayed only within the R-S7 and V-S7 palaeosol, respectively.

2. The position of the Stage 17 (670 ka), Kamikatsura ( 850-900 ka) excursions at Roksolany and the Unnamed event (430 ka) at Vyazivok is concordant with Danube loess magnetostratigraphy (Sümegi et al., 2018). Palaeomagnetic events established in different loess-palaeosol sequences can reasonably serve as a reference for chronostratigraphic models.

3. Due to the similarity of magnetic susceptibility and marine oxygen isotope records, we suggest the Roksolany and Vyazivok sections as among the most complete palaeoenvironmental continental archives of the past 1 My not only in Ukraine, but in Eurasia. High-resolution MS data have revealed the multi-stage and substage structures corresponding to rhythms of palaeopedogenic development, which are clearly comparable to marine oxygen isotope variations. The sections studied can be considered as unique benchmarks for global interprofile correlations.

4. The chronostratigraphy of the Roksolany and Vyazivok sequences has been revised to fit the position of the MBB. Based on previous palaeoenvironmental, pedological, geochronological and sedimentation studies, our revision was extended to the loess-palaeosol sequence in the central forest-steppe and southern steppe areas of Ukraine in order to facilitate the interpretation of climatic connections with the loess records in the Danube Basin and on the Chinese Loess Plateau

5. The Roksolany Tephra in MIS 6 loess unit R-L2 can be correlated with the L2 Tephra, which is widely distributed in southeastern European loess sites and lacustrine archives. The L2 Tephra serves as an important marker horizon; however, more information, such as a mineralogical comparison and an individually determined age and origin, is required.

6. The conducted studies have revealed that the Zavadivka superunit contains two interglacial soil units, the U-S4 (MIS 11) and U-S3 (MIS 9). Due to the absence of a satisfactory stratotype of the Middle Zavadivka (U-L4, MIS 10) loess in Ukraine, the Roksolany section may be considered as the regional lectostratotype of this stratigraphic unit.

Acknowledgements. This research was partly supported by grants 0117U003498, 0119 U102394 from the National Academy of Sciences of Ukraine. We wish to thank P. Gozhik, Zh. Matviishyna, N. Gerasimenko, A. Bogutskyi and S. Prylypko for their assistance in stratigraphic correlation of samples. We thank le. Poliachenko, V. Shpyra, V. Yakukhno for their help in field works. Also it is a pleasure to thank the Palaeomagnetism Team, operating within the Department of Magnetism of the Institute of Geophysics of the Polish Academy of Sciences, for access to equipment and for advice provided to us. We would like to extend sincere thanks to the P. Sümegi, D. Jordanova, T. Elbra and an anonymous reviewer for their constructive reviews and useful comments, which greatly improved the quality of the manuscript. 


\section{REFERENCES}

Bakhmutov, V.G., Hlavatskyi, D.V., 2014. Identification of the Matuyama-Brunhes boundary by paleomagnetic studies of the Roxolany profile (Western Black Sea region) (in Russian with English summary). Dopovidi Natsionalnoyi Akademiyi Nauk Ukrayiny, 10: 92-98.

Bakhmutov, V.G., Glavatskiy, D.V., 2016. Problems of magnetostratigraphy of Pleistocene loess-soil deposits in the South of Ukraine (in Russian with English summary). Geofizicheskiy Zhurnal, 38: 59-75.

Bakhmutov, V.G., Kazanskii, A.Yu., Matasova, G.G., Glavatskii, D.V., 2017. Rock magnetism and magnetostratigraphy of the loess-sol series of Ukraine (Roksolany, Boyanychi, and Korshev sections). Izvestiya, Physics of the Solid Earth, 53: 65-86.

Balescu, S., Lamothe, M., Panaiotu, C., Panaoitu, C., 2010. IRSL chronology of eastern Romanian loess sequences (in French with English summary). Quaternaire, 21: 115-126.

Bogucki, A., Łanczont, M., Gozhik, P., Komar, M., 2013. Roksolany loess section: location, research history and characteristics of deposits (in Polish and Ukrainian with English summary). In: Loess cover of the North Black Sea Region. Proceeding of the XVIII Ukrainian-Polish Workshop 8-13 September 2013 (eds. A. Bogucki, P. Gozhik, M. Łanczont, T. Madejska and Y. Yelovicheva): 34-58. KARTPOL s.c. Lublin, Lublin.

Bogutskyi, A., Tomenyuk, O., 2013. XVIII Ukrayinsko-polskyi seminar "Lesovyi pokryv Pivnichnoho Prychornomorya" (in Ukrainian). Visnyk of the Lviv University. Series Geography, 42 379-381.

Bolikhovskaya, N.S., Molodkov, A.N., 2006. East European loess-palaeosol sequences: Palynology, stratigraphy and correlation. Quaternary International, 149: 24-36.

Bolshakov, V.A., 2008. On the paleomagnetism of loesses and correlation of the Belovo and Volodarka sections (the Ob River region). Izvestiya, Physics of the Solid Earth, 44: 593-602.

Bolshakov, V.A., 2017. The use of the rock magnetic and paleomagnetic data for the loess plateau deposits in China for their climatologic and chronologic correlation to the oxygen isotopic timescale. Izvestiya, Physics of the Solid Earth, 53: 293-310.

Bradák, B., Seto, Y., Nawrocki, J., 2019. Significant pedogenic and palaeoenvironmental changes during the early Middle Pleistocene in Central Europe. Palaeogeography, Palaeoclimatology, Palaeoecology, 534: 109335.

Buggle, B., Glaser, B., Zöller, L., Hambach, U., Marković, S., Glaser, I., Gerasimenko, N., 2008. Geochemical characterization and origin of Southeastern and Eastern European loesses (Serbia, Romania, Ukraine). Quaternary Science Reviews, 27: 1058-1075.

Buggle, B., Hambach, B., Glaser, B., Gerasimenko, N., Marković, S., Glaser, I., Zöller, L., 2009. Stratigraphy, and spatial and temporal paleoclimatic trends in Southeastern/Eastern European loess-paleosol sequences. Quaternary International, 196: 86-106.

Chadima, M., Hrouda, F., 2006. Remasoft 3.0 a user-friendly paleomagnetic data browser and analyzer. Travaux Geophysiques, 27: 20-21.

Chepalyga, A.L., 1967. Antropogenovyye presnovodnyye mollyuski yuga Russkoy ravniny i ikh stratigraficheskoye znacheniye (in Russian). Nauka, Moscow.

Chlebowski, R., Gozhik, P., Lindner, L., Łanczont, M., Wojtanowicz, J., 2003. Stratigraphy and sedimentology of the Bug loess (Pleistocene: Upper Vistulian) between Kiev and Odessa (Ukraine). Geological Quarterly, 47 (3): 261-268.

Colleoni, F., Wekerle, C., Näslund, J.-O., Brandefelt, J., Masina, S., 2016. Constraint on the penultimate glacial maximum Northern Hemisphere ice topography ( 140 kyrs BP). Quaternary Science Reviews, 137: 97-112.

Constantin, D., Veres, D., Panaiotu, C., Anechitei-Deacu, V., Groza, S.M., Begy, R., Kelemen, S., Buylaert, J.-P., Hambach, U., Marković, S.B., Gerasimenko, N., Timar-Gabor, A., 2019. Luminescence age constraints on the Pleistocene-Holocene transition recorded in loess sequences across SE Europe. Quaternary Geochronology, 49: 71-77.
Ding, Z., Yu, Z., Rutter, N.W., Liu, T., 1994. Towards an orbital time scale for Chinese loess deposits. Quaternary Science Reviews, 13: $39-70$.

Ding, Z.L., Derbyshire, E., Yang, S.L., Yu, Z.W., Xiong, S.F., 2002. Stacked 2.6-Ma grain size record from the Chinese loess based on five sections and correlation with the deep sea $\delta^{18} \mathrm{O}$ record. Paleoceanography, 17: 5-1-5-21.

Dodonov, A.E., Zhou, L.P., Markova, A.K., Tchepalyga, A.L., Trubikin, V.M., Aleksandrowski, A.L., Simakova, A.N., 2006. Middle-Upper Pleistocene bio-climatic and magnetic records of the Northern Black Sea Coastal Area. Quaternary International, 149: 44-54.

Ehlers, J., Astakhov, V., Gibbard, P.L., Mangerud, J., Svendsen, J.I., 2013. Middle Pleistocene in Eurasia. In: Encyclopedia of Quaternary Science, 2nd edition (eds. Elias S.A., Mock C.M.), 2: 172-179. Elsevier, Amsterdam.

Fedorowicz, S., Łanczont, M., Bogucki, A., Woźniak, P.P., Wróblewski, R., Adamiec, G., Bluszcz, A., Moska, P., 2013. Isotope dating in Roksolany loess profile (in Polish with English summary). In: Loess cover of the North Black Sea Region. Proceeding of the XVIII Ukrainian-Polish Workshop 8-13 September 2013 (eds. A. Bogucki, P. Gozhik, M. Łanczont, T. Madejska and J. Yelovicheva): 65-68. KARTPOL s.c. Lublin, Lublin.

Fedorowicz, S., Woźniak, P.P., Hałas, S., Łanczont, M., Paszkowski, M., Wójtowicz, A., 2012. Challenging K-Ar dating of the Quaternary tephra from Roxolany. Mineralogia, 39: 102-105.

Fitzsimmons, K.E., Marković, S.B., Hambach, U., 2012. Pleistocene environmental dynamics recorded in the loess of the middle and lower Danube basin. Quaternary Science Reviews, 41: 104-118.

Gendler, T.S., Heller, F., Tsatskin, A., Spassov, S., Du Pasquier, J., Faustov, S.S., 2006. Roxolany and Novaya Etuliya - key sections in the western Black Sea loess area: Magnetostratigraphy, rock magnetism, and paleopedology. Quaternary International, 152-153: 78-93.

Gerasimenko, N., 2006. Upper Pleistocene loess-palaeosol and vegetational successions in the Middle Dnieper Area, Ukraine. Quaternary International, 149: 55-66.

Gerasimenko, N., Matvijishyna, Zh., 2007. The problems of Zavadiv "great interglacial" (in Ukrainian with English summary). In: Problems of Middle Pleistocene interglacial. Proceeding of the XIV Ukrainian-Polish Workshop 12-16 September 2007 (eds. A. Bogucki, P. Gozhik, M. Łanczont, T. Madejska and Y. Yelovicheva): 194-206. Vydavnychyi tsentr LNU imeni Ivana Franka, Lviv.

Gerasimenko, N.P., 2004. Quaternary Evolution of Zonal Paleoecosystems in Ukraine (in Ukrainian with English summary). Institute of Geography NASU, Kyiv.

Gozhik, P., 2013. Research problems of the Roksolany section (in Ukrainian with English summary). In: Loess cover of the North Black Sea Region. Proceeding of the XVIII Ukrainian-Polish Workshop 8-13 September 2013 (eds. A. Bogucki, P. Gozhik, M. Łanczont, T. Madejska and Y. Yelovicheva): 17-33. KARTPOL s.c. Lublin, Lublin.

Gozhik, P., Komar, M., Krokhmal, O., Shovkoplias, V., Khrystoforova, T., Dykan, N., Prylypko, S., 2007. The key section of Neopleistocene subaerial deposits near Roxolany village (Odessa region) (in Ukrainian with English summary). In: Problems of Middle Pleistocene interglacial. Proceeding of the XIV Ukrainian-Polish Workshop 12-16 September 2007 (eds. A. Bogucki, P. Gozhik, M. Łanczont, T. Madejska and Y. Yelovicheva): 109-128. Vydavnychyi tsentr LNU imeni Ivana Franka, Lviv.

Gozhik, P., Shelkoplyas, V., Khristoforova, T., 1995. Development Stages of loessial and facial formation in Ukraine (Stratigraphy of loess in Ukraine). Annales Universitae Mariae $\mathrm{Cu}$ rie-Sklodowska (B), 50: 65-74

Gozhik, P.F., 1976. Putevoditel' VIII Mezhdunarodnogo simpoziuma po lessovym porodam (in Russian) (eds., P.F. Gozhik, Yu.G. Chugunnyi and V.I. Melnik). Naukova Dumka, Kyiv. 
Gozhik, P.F., Gerasimenko, N.P., 2011. The lower and middle Pleistocene of Ukraine. In: Quaternary studies in Ukraine (eds. N.P. Gerasimenko, P.F. Gozhik, N.I. Dykan, Zh.M. Matviishyna V.M. Shelkoplyas and B.D. Vozgrin): 9-26. Institute of Geological Sciences NASU, Kyiv.

Gozhik, P.F., Shelkoplyas, V.N., Komar, M.S., Matviishyna, Z.M., Perederiy, V.I., 2000. Putivnyk X polsko-ukrayinskoho seminaru "Korelyatsiya lesiv i lodovykovykh vidkladiv Polshchi i Ukrayiny" (in Ukrainian). Kyiv.

Gozhyk, P.F., 2012. Stratigraphic Code of Ukraine (in Ukrainian with English summary) (ed. P.F. Gozhyk). Kyiv, National Stratigraphic Committee of Ukraine.

Guidebook, 1982, for Excursions A-7, C-7 Moldovia and the Odessa Region. XI Congress INQUA, Moscow.

Haase, D., Fink, J., Haase, G., Ruske, R., Pesci, M., Richter, H., Altermann, M., Jager, K.-D., 2007. Loess in Europe - Its spatial distribution based on a European Loess Map, scale 1:2,500,000. Quaternary Science Reviews, 26: 1301-1312.

Hambach, U., Jovanović, M., Marković, S.B., Nowaczyk, N., Rolf, C., 2009. The Matuyama-Brunhes geomagnetic reversal in the Stari Slankamen loess section (Vojvodina, Serbia): its detailed record and its stratigraphic position. Geophysical Research Abstracts, 11: EGU2009e0

Head, M.J., Gibbard, P.L., 2015. Early-Middle Pleistocene transitions: linking terrestrial and marine realms. Quaternary International, 389: 7-46.

Heller, F., Liu, T.S., 1982. Magnetostratigraphical dating of loess deposits in China. Nature, 300: 431-433.

Heller, F., Liu, T.S., 1984. Magnetism of Chinese loess deposits. Geophysical Journal of the Royal Astronomical Society, 77 125-141.

Heller, F., Sartori, M., Hus, J., Geeraerts, R., Hailwood, E., Montgomery, P., Gendler, T., Bagin, V., Virina, E., Tsatskin, A. 1996. Paleoenvironmental change documented by magnetic investigations at Roxolany, a loess type section near Odessa (Ukraine). Geologica Carpatica, 47: 208-209.

Heslop, D., Langereis, C.G., Dekkers, M.J., 2000. A new astronomical timescale for the loess deposits of northern China Earth and Planetary Science Letters, 184: 125-139.

Hlavatskyi, D.V., 2019. Refined magnetostratigraphic position of the Shyrokyne unit in loess sequences from Central Ukraine. Journal of Geology, Geography and Geoecology, 28: 301-312.

Hlavatskyi, D., Bakhmutov, V., 2018a. Magnetostratigraphy and rock magnetism of Quaternary loess-paleosol sequences from Ukraine. Geophysical Research Abstracts, 20 : EGU2018-853-1. EGU General Assembly, Vienna, Austria.

Hlavatskyi, D., Bakhmutov, V., 2018b. Position of the Matuyama-Brunhes Boundary in Pleistocene Subaerial Formation of Ukraine. Publications of the Institute of Geophysics, Polish Academy of Sciences. Geophysical Data Bases, Processing and Instrumentation. 423 (C-112): 63-64.

Hlavatskyi, D.V., Bakhmutov, V.G., 2019. Magnetostratigraphy of the key loess-palaesol sequence at Roxolany (Western Black Sea region). In: Recent Advances in Rock Magnetism, Environmental Magnetism and Paleomagnetism. Springer Geophysics (eds. D. Nurgaliev, V. Shcherbakov, A. Kosterov and S. Spassov): 371-382. Springer, Cham.

Hlavatskyi, D., Bakhmutov, V., Bogucki, A., Voloshyn, P., 2016a. Petromagnetism and paleomagnetism of subaerial deposits of Boyanychi and Korshiv sections (Volhynian Upland) (in Ukrainian with English summary). Visnyk of Taras Shevchenko National University of Kyiv: Geology, 72: 43-51.

Hlavatskyi, D.V., Kuzina, D.M., Gerasimenko, N.P., Bakhmutov, V.G., 2016b. Petromagnetism and paleomagnetism of Quaternary loess-soil sediments of Vyazivok section (Dnieper Lowland) (in Russian with English summary). Geofizicheskiy Zhurnal, 38: 186-193.

Hus, J., Han, J., 1992. The contribution of loess magnetism in China to the retrieval of past global changes - some problems Physics of the Earth and Planetary Interiors, 70: 154-168.

Hyodo, M., 1984. Possibility of reconstruction of the past geomagnetic field from homogeneous sediments. Journal of Geomagnetism and Geoelectricity, 36: 45-62.
Jansen, J.H.F., Kuijpers, A., Troelstra, S.R., 1986. A Mid-Brunhes Climatic Event: Long-Term Changes in Global Atmosphere and Ocean Circulation. Science, 232: 619-622.

Jin, C.S., Liu, Q.S., 2011. Revisiting the stratigraphic position of the Matuyama-Brunhes geomagnetic polarity boundary in Chinese loess. Palaeogeography, Palaeoclimatology, Palaeoecology, 299: 309-317

Jin, C., Liu, Q., Xu, D., Sun, J., Li, C., Zhang, Y., Han, P., Liang, W., 2019. A new correlation between Chinese loess and deep-sea $\delta^{18} \mathrm{O}$ records since the middle Pleistocene. Earth and Planetary Science Letters, 506: 411-454.

Jordanova, D., Petersen, N., 1999. Paleoclimatic record from a loess-soil profile in northeastern Bulgaria II. Correlation with global climatic events during the Pleistocene. Geophysical Journal International, 138: 533-540.

Jordanova, D., Hus, J., Geeraerts, R., 2007. Palaeoclimatic implications of the magnetic record from loess/palaeosol sequence Viatovo (NE Bulgaria). Geophysical Journal International, 171: 1036-1047.

Kirschvink, J.L., 1980. The least squares line and plane and the analysis of palaeomagnetic data. Geophysical Journal of the Royal Astronomical Society, 62: 699-718.

Kolfschoten, T., Markova, A.K., 2005. Response of the European mammalian fauna to the mid-Pleistocene transition. Special Publications, 247: 221-229.

Krokhmal, A.I., 2009. Eopleistocene sediments biostratification of central part of the northern Black Sea coastal (in Russian with English summary). Zbirnyk naukovykh prats Instytutu geolohichnykh nauk NAN Ukrayiny, 2: 194-199.

Krokos, V.I., 1932. Kratkiy ocherk chetvertichnykh otlozheniy Ukrainy (in Russian). Chetvertynnyi Period, 3: 17-55.

Kukla, G., Heller, F., Liu, X.M., Xu, T.C., Liu, T.S., An, Z.S., 1988 Pleistocene climates in China dated by magnetic susceptibility. Geology, 16: 811-814.

Kukla, G.J., 1987. Loess stratigraphy in Central China. Quaternary Science Reviews, 6: 191-219.

Laag, C., Hambach, U., Botezatu, Y., Baykal, A., Veres, D., Schönwetter, T., Viola, J., Zeeden, C., Radaković, M.G. Obreht, I., Jovanović, M., Bösken, J.J., Lehmkuhl, F., Marković, S.B., 2018. The geographical extent of the "L2-Tephra": a widespread marker horizon for the penultimate glacial (MIS 6) on the Balkan Peninsula. In: Crossing New Frontiers: INTAV International Field Conference on Tephrochronology "Tephra Hunt in Transylvania". Book of Abstracts (eds. U. Hambach and D. Veres): 111-111.

Laj, C., Channell, J.E.T., 2007. Geomagnetic Excursions. In: Treatise on Geophysics: 373-416.

Łanczont, M., Madeyska, T., Bogucki, A., Mroczek, P., Hołub, B., Łącka, B., Fedorowicz, S., Nawrocki, J., Frankowski, Z., Standzikowski, K., 2015. Środowisko abiotyczne paleolitycznej ekumeny strefy pery- i metakarpackiej (in Polish with Ukrainian summary). In: Palaeolithic oecumene in the periand meta-Carpathian zone (eds. M. Łanczont and T. Madeyska): 55-458. Wydawnictwo UMCS, Lublin.

Lindner, L., Gozhik, P., Marciniak, B., Marks, L., Yelovicheva, Y., 2004. Main climatic changes in the Quaternary of Poland, Belarus and Ukraine. Geological Quarterly, 48 (2): 97-114.

Lindner, L., Bogutsky, A., Gozhik, P., Marks, L., Kanczont, M., Wojtanowicz, J., 2006. Correlation of Pleistocene deposits in the area between the Baltic and Black Sea, Central Europe. Geological Quarterly, 50 (1): 195-210.

Lisiecki, L.E., Raymo, M.E., 2005. A Pliocene-Pleistocene stack of 57 globally distributed benthic $\delta^{18} \mathrm{O}$ records. Paleoceanography, 20: PA1003.

Liu, Q., Chunsheng, J., Pengxiang, H., Zhaoxia, J., Kunpeng, G., Roberts, A., 2015. Magnetostratigraphy of Chinese loess-paleosol sequences. Earth-Science Reviews, 150 139-167.

Liu, Q., Roberts, A.P., Rohling, E.J., Zhu, R., Sun, Y., 2008. Post-depositional remanent magnetization lock-in and the location of the Matuyama-Brunhes geomagnetic reversal boundary in marine and Chinese loess sequences. Earth and Planetary Science Letters, 275: 102-110. 
Liu, T.S., 1985. Loess and Environment: 31-67. China Ocean Press, Beijing.

Lomax, J., Fuchs, M., Antoine, P., Fuchs, M., Antoine, P., Rousseau, D.-D., Lagroix, F., Hatté, C., Taylor, S.N., Till, J.L., Debret, M., Moine, O., Jordanova, D., 2019. A luminescence-based chronology for the Harletz loess sequence, Bulgaria. Boreas, 48: 179-194.

Lu, H., Liu, X., Zhang, F., 1999. Astronomical calibration of loess-paleosol deposits at Luochuan, central Chinese Loess Plateau. Palaeogeography, Palaeoclimatology, Palaeoecology, 154: 237-246.

Maher, B.A., 1998. Magnetic properties of modern soils and Quaternary loessic paleosols: paleoclimatic implications. Palaeogeography, Palaeoclimatology, Palaeoecology, 137: 25-54.

Man, O., 2008. On the identification of magnetostratigraphic polarity zones. Studia Geophysica at Geodaetica, 52: 173-186.

Marković, S.B., Hambach, U., Stevens, T., Jovanović, M., O'Hara-Dhand, K., Basarin, B., Lu, H., Smalley, I., Buggle, B., Zech, M., Svirčev, Z., Sümegi, P., Milojković, N., \& Zöller, L., 2012. Loess in the Vojvodina region (Northern Serbia): an essential link between European and Asian Pleistocene environments. Geologie en Mijnbouw/Netherlands Journal of Geosciences, 91: 173-188.

Marković, S.B., Hambach, U., Stevens, T., Kukla, G.J., Heller, F., McCoy, W.D., Oches, E.A., Buggle, B., Zöller, L., 2011. The last million years recorded at the Stari Slankamen loess-palaeosol sequence: revised chronostratigraphy and long-term environmental trends. Quaternary Science Reviews, 30: $1142-1154$

Marković, S.B., Stevens, T., Kukla, G.J., Hambach, U., Fitzsimmons, K.E., Gibbard, P., Buggle, B., Zech, M., Guo, Z., Hao, Q., Wu, H., O'Hara Dhand, K., Smalley, I.J., Újvári, G., Sümegi, P., Timar-Gabor, A., Veres, D., Sirocko, F., Vasiljević, D.A., Jary, Z., Svensson, A., Jović, V., Lehmkuhl, F., Kovács, J., Svirčev, Z., 2015. Danube loess stratigraphy Towards a pan-European loess stratigraphic model. Earth Science Reviews, 148: 228-258.

Matsuzaki, K.M., Nishi, H., Suzuki, N., Cortese, G., Eynaud, F., Takashima, R., Kawate, Y., Sakai, T., 2014 Paleoceanographic history of the Northwest Pacific Ocean over the past $740 \mathrm{kyr}$, discerned from radiolarian fauna. Palaeogeography, Palaeoclimatology, Palaeoecology, 396: 26-40.

Matviishina, Zh., Mel'nichuk, I., Perederyi, V., Gerasimenko, N., 2001. Vyazivok section. In: The Ukraine Quaternary explored: the Middle and Upper Pleistocene of the Middle Dnieper area and its importance for the East-West European correlation. Excursion guide of the SEQS 2001 conference, Ukraine: 23-36. Institute of Geological Sciences NASU, Kyiv.

Matviishyna, Zh.M., Gerasimenko, N.P., Perederyi, V.I., Bragin, A.M., Ivchenko, A.S., Karmazinenko, S.P., Nagirnyi, V.M., Parkhomenko, O.G., 2010. Spatio-temporal correlation of Quaternary palaeogeographic conditions on the territory of Ukraine (in Ukrainian with English summary). Naukova Dumka, Kyiv.

Nawrocki, J., Bakhmutov, V., Bogucki, A., Dolecki, L. 1999. The paleo- and petromagnetic record in the Polish and Ukrainian loess-paleosol sequences. Physics and Chemistry of the Earth (A), 24: 773-777

Nawrocki, J., Bogucki, A., Łanczont, M., Nowaczyk, N., 2002. The Matuyama-Brunhes boundary and the nature of magnetic remanence aquisition in the loess-paleosol sequences from the western part of the East European Loess province. Palaeogeography, Palaeoclimatology, Palaeoecology, 188: 39-50.

Nawrocki, J., Gozhik, P., Łanczont, M., Pańczyk, M., Komar, M., Bogucki, A., Williams, J.S., Czupy, Z., 2018. Palaeowind directions and sources of detrital material archived in the Roxolany loess section (southern Ukraine). Palaeogeography, Palaeoclimatology, Palaeoecology, 496: 121-135.

Necula, C., Dimofte, D., Panaiotu, C., 2015. Rock magnetism of a loess-palaeosol sequence from the western Black Sea shore (Romania). Geophysical Journal International, 202: 1733-1748.

Nomade, S., Bassinot, F., Marino, M., Simon, Q., Dewilde, F., Maiorano, P., Isguder, G., Blamart, D., Girone, A., Scao, V., Pereira, A., Toti, F., Bertini, A., Combourieu-Nebout, N., Peral, M., Bourlčs, D.L., Petrosino, P., Ciaranfi, N., 2019.
High-resolution foraminifer stable isotope record of MIS 19 at Montalbano Jonico, southern Italy: A window into Mediterranean climatic variability during a low-eccentricity interglacial. Quaternary Science Reviews, 205: 106-125.

Obreht, I., Zeeden, C., Hambach, U., Veres, D., Marković, S.B., Bösken, J., Svirčev, Z., Bačević, N., Gavrilov, M.B. Lehmkuhl, F., 2016. Tracing the influence of Mediterranean climate on Southeastern Europe during the past 350,000 years. Scientific Reports, 6: 36334.

Pan, Y.X., Zhu, R.X., Liu, Q.S., Guo, B., Yue, L.P., Wu, H.N., 2002. Geomagnetic episodes of the last $1.2 \mathrm{Myr}$ recorded in Chinese loess. Geophysical Research Letters, 29: 1282.

Panaiotu, C.G., Panaiotu, E.C., Grama, A. Necula, C., 2001. Paleoclimatic record from a loess-paleosol profile in Southeastern Romania. Physics and Chemistry of the Earth (A), 26 893-898.

Railsback, B.L., Gibbard, P.L., Head, M.J., Voarintsoa Ny, R.G., Toucanne, S., 2015. An optimized scheme of lettered marine isotope substages for the last 1.0 million years, and the climatostratigraphic nature of isotope stages and substages. Quaternary Science Reviews, 111: 94-106.

Rousseau, D.-D., Gerasimenko, N., Matviischina, Zh., Kukla, G., 2001. Late Pleistocene Environments of the Central Ukraine. Quaternary Research, 56: 349-356.

Sartori, M., 2000. The Quaternary climate in loess sediments: Evidence from rock and mineral magnetic and geochemical analysis. Ph.D. thesis. Swiss Federal Institute of Technology, Zurich.

Schmidt, P.W., 1993. Paleomagnetic cleaning strategies. Physics of the Earth and Planetary Interiors, 76: 169-178.

Shackleton, N.J., Berger, A., Peltier, W.R., 1990. An alternative astronomical calibration of the lower Pleistocene timescale based on ODP Site 677. Transactions of the Royal Society of Edinburgh Earth Sciences, 81: 251-261.

Sharonova, Z.V., Pilipenko, O.V., Trubikhin, V.M., Didenko, A.N., Feyn, A.G., 2004. Restoration of geomagnetic field according to paleomagnetic records in loess-soil section Roxolany (Dnestr river, Ukraine) for last 75000 years (in Russian with English summary). Fizika Zemli, 1: 4-13.

Singer, B.S., Hoffman, K.A., Coe, R.S., Brown, L.L., Jicha, B.R., Pringle, M.S., Chauvin, A., 2005. Structural and temporal requirements for geomagnetic field reversal deduced from lava flows. Nature, 434: 633-636.

Sirenko, N.A., Turlo, S.I., 1986. Razvitiye pochv i rastitel'nosti Ukrainy $\mathrm{v}$ pliotsene $\mathrm{i}$ pleystotsene (in Russian). Naukova dumka, Kyiv.

Sirenko, O., 2017. Subaeral Eopleistocene-Lower Neopleistocene deposits of the plain part of Ukraine and their palynological characteristic. Dnipropetrovsk University Bulletin. Series: geology, geography, 25: 101-118.

Sirenko, O., 2019. Changes in Pleistocene vegetation and climate of Ukraine in the range of 1.8-0.4 million years. Journal of Geology, Geography and Geoecology, 28: 355-366.

Sirenko, O.A., Bahmutov, V.G., Nikitichenko, I.M., 2008. New data for studing Neopleistocene deposits of Nonglacial zone of the Ukrainian Shield (in Ukrainian with English summary). Geologichnyi Zhurnal, 325: 113-122.

Song, Y., Guo, Z., Marković, S., Hambach, U., Deng, C., Chang, L., Wu, J., Hao, Q., 2018. Magnetic stratigraphy of the Danube loess: a composite Titel-Stari Slankamen loess section over the last one million years in Vojvodina, Serbia. Journal of Asian Earth Sciences, 155: 68-80.

Spassov, S., Heller, F., Evans, M.E., Yue, L.P., Ding, Z.L., 2001. The Matuyama/Brunhes geomagnetic polarity transition at Lingtai and Baoji, Chinese Loess Plateau. Physics and Chemistry of the Earth (A), 26: 899-904

Spassov, S., Heller, F., Evans, M.E., Yue, L.P., von Dobeneck, T., 2003. A lock-in model for the complex Matuyama-Brunhes boundary record of the loess/palaeosol sequence at Lingtai (Central Chinese Loess Plateau). Geophysical Journal International, 155: 350-366.

Sümegi, P., Gulyás, S., Molnár, D., Sümegi, B.P., Almond, P.C., Vandenberghe, J., Zhou, L., Pál-Molnár, E., Töröcsik, T., Hao, Q., Smalley, I., Molnár, M., Marsi, I., 2018. New chronology of the best developed loess/paleosol sequence of Hungary 
capturing the past $1.1 \mathrm{ma}$ : Implications for correlation and proposed pan-Eurasian stratigraphic schemes. Quaternary Science Reviews, 191: 144-166.

Sümegi, P., Gulyás, S., Molnár, D., Sümegi, B.P., Törőcsik, T., Almond, P.C., Koloszár, L., 2019. Periodicities of paleoclimate variations in the first high-resolution non-orbitally tuned grain size record of the past $1 \mathrm{Ma}$ from SW Hungary and regional global correlations. Aeolian Research, 40: 74-90.

Tauxe, L., Herbert, T., Shackleton, N.J., Kok, Y.S., 1996. Astronomical calibration of the Matuyama-Brunhes boundary: consequences for magnetic remanence acquisition in marine carbonates and the Asian loess sequences. Earth and Planetary Science Letters, 140: 133-146.

Tecsa, V., Gerasimenko, N., Veres, D., Hambach, U., Lehmkuhl, F., Schulte, P., Timar-Gabor, A., 2020. Revisiting the chronostratigraphy of Late Pleistocene loess-paleosol sequences in southwestern Ukraine: OSL dating of Kurortne section. Quaternary International, 542: 65-79.

Tretyak, A.N., 1980. Regim of the Pleistocene geomagnetic field and structure of the Brunhes geomagnetic epoch (in Russian with English summary). Geofizicheskiy Zhurnal, 5: 75-87.

Tretyak, A.N., 1983. Estestvennaya ostatochnaya namagnichennost' i problema paleomagnitnoy stratifikatsii osadochnykh tolshh (in Russian). Naukova Dumka, Kyiv.

Tretyak, A.N., Vigilyanskaya, L.I., 1994. Magnetostratigraphic scale of Pleistocene of Ukraine (in Russian with English summary). Geofizicheskiy Zhurnal, 16: 3-14.

Tretyak, A.N., Shevchenko, A.I., Dudkin, V.P., Vigilyanskaya, L.I., 1987. Paleomagnitnaya stratigrafiya opornykh razrezov pozdnego kaynozoya yuga Ukrainy (in Russian). Institute of Geological Sciences AS USSR, Kyiv.

Tretyak, A.N., Vigilyanskaya, L.I., Makarenko, V.N., Dudkin, V.P., 1989. Tonkaya struktura geomagnitnogo polya $\vee$ pozdnem kaynozoye (in Russian). Naukova Dumka, Kyiv.

Tretyak, A.N., Volok, Z.E., 1976. Paleomagnitnaya stratigrafiya pliotsen-chetvertichnykh osadochnykh tolshch Ukrainy (in Russian). Naukova Dumka, Kyiv.

Tsatskin, A., Heller, F., Gendler, T.S., Virina, E.I., Spassov, S., Du Pasquier, J., Hus, J., Hailwood, E.A., Bagin, V.I., Faustov, S.S., 2001. A new scheme of terrestrial paleoclimate evolution during the last $1.5 \mathrm{Ma}$ in the western Black Sea region: integration of soil studies and loess magmatism. Physics and Chemistry of the Earth, 26: 911-916.

Tsatskin, A., Heller, F., Hailwood, E.A., Gendler, T.S., Hus, J., Montgomery, P., Sartori, M., Virina, E.I., 1998. Pedosedimentary division, rock magnetism and chronology of the loess/palaesol sequence at Roxolany (Ukraine). Palaeogeography, Palaeoclimatology, Palaeoecology, 143: 111-133.

Veklich, M.F., 1968. Stratigrafiya lessovoy formatsii Ukrainy i sosednikh stran (in Russian). Naukova Dumka, Kyiv.

Veklich, M.F., 1982. Paleoetapnost' i stratotipy pochvennykh formatsiy verkhnego kaynozoya (in Russian). Naukova Dumka, Kyiv

Veklich, M.F., 1987. Problemy paleoklimatologiyi (in Russian). Naukova Dumka, Kyiv.

Veklich, M.F., 1995. Correlation of the Pleistocene paleogeographical stages: ocean-loess areas-the Black Sea (in Russian with English summary). In: Correlation of Paleogeographica Events: Continent-Shelf-Ocean (ed. A.A. Svitoch): 27-33. Moscow University Press, Moscow.

Veklich, M.F., Artyushenko, A.T., Sirenko, N.A., Dubnyak, V.A., Mel'nichuk, I.V., Parishkura, S.I., 1967. Opornyye geologicheskiye razrezy antropogena Ukrainy (in Russian): 13-50. Naukova Dumka, Kyiv.

Veklich, M.F., Sirenko, N.A., Matviishina, Z.N., Gerasimenko, N.P., Perederiy, V.I., Turlo, S.I., 1993. Stratigraficheskaya skhema chetvertichnykh otlozheniy Ukrainy (in Russian). In Stratigraficheskiye skhemy fanerozoya i dokembriya. Goskomgeologia of Ukraine, Kyiv.

Veklich, M.F., Sirenko, N.A., Matviyishina, Zh.N., 1984a. Paleogeograficheskiye etapy i detal'noye stratigraficheskoye raschleneniye pleystotsena Ukrainy (in Russian). Naukova Dumka, Kyiv.

Veklich, M.F., Sirenko, N.A., Volkov, N.G., Shelkoplyas, V.N., Dubniak, V.A., Kovniets, N.L., Lavrushin, Yu.A., Matviishyna, Zh.N., Melnichuk, I.V., Nagirny, V.N., Perederiy, V.I., Solovitsky, V.N., Turlo, S.I., Chugunny, Yu.G., Barshchevsky, N.E., Vozgrin, B.D., Gerasimenko, N.P., Gladkikh, M.I., Kolomiets, G.D., 1984b. Excursion 025 - Quaternary geology of the Dnieper area. In: Guidebook Intern. Geol. Congr., Session 25: 64-81. Kyiv.

Velichko, A.A., 1990. Loess-paleosol formation on the Russian Plain. Quaternary International, 7/8: 103-114.

Vigilyanskaya, L.I., 2001. Paleomagnetic section and magnetic properties of Quaternary deposits of the Viazivok site. In: The Ukraine Quaternary explored: the Middle and Upper Pleistocene of the Middle Dnieper area and its importance for the East-West European correlation. Abstracts of the SEQS 2001 conference: 97. Institute of Geological Sciences NASU, Kyiv.

Vigilyanskaya, L.I., Tretyak, A.N., 2000. Palaeomagnetism of key Pliocene-Pleistocene sections in North-Western Donbass (in Russian with English summary). Geofizicheskiy Zhurnal, 22: 96-104.

Vigilyanskaya, L.I., Tretyak, A.N., 2002. Palaeomagnetic studies of Pliocene-Pleistocene deposits of loess-palaeosol stratum in Middle Dnieper region (in Russian with English summary). Geofizicheskiy Zhurnal, 24: 36-42.

Vozgrin, B.D., 2001. Problemy stratyhrafichnoho rozchlenuvannya ta korelyatsii kontynentalnykh vidkladiv antropohenu Ukrayiny (in Ukrainian). In: Rehionalni heolohichni doslidzhennya v Ukrayini i pytannya stvorennya Derzhheolkarty - 2001. The State Geological Survey, Ukrainian State Research Institute for Geological Survey, Kyiv.

Wang, X., Lovlie, R., Chen, Y., Yang, Z., Pei, J., Tang, L., 2014. The Matuyama-Brunhes polarity reversal in four Chinese loess records: high fidelity recording of geomagnetic field behavior or a less than reliable chronostratigraphic marker? Quaternary Science Reviews, 101: 61-76.

Wang, X.S., Yang, Z.Y., Løvlie, R., Sun, Z.M., Pei, J.L., 2006. A magnetostratigraphic reassessment of correlation between Chinese loess and marine oxygen isotope records over the last 1.1 Ma. Physics of the Earth and Planetary Interiors, 159: 109-117.

Wulf, S., Fedorowicz, S., Veres, D., Łanczont, M., Karátson, D., Gertisser, R., Bormann, M., Magyari, E., Appelt, O., Hambach, U., Gozhik, P.F., 2016. The 'Roxolany Tephra' (Ukraine) - new evidence for an origin from Ciomadul volcano, East Carpathians. Journal of Quaternary Science, 31: 565-576.

Yang, T.S., Hyodo, M., Yang, Z.Y., Li, H.D., Maeda, M., 2010. Multiple rapid polarity swings during the Matuyama-Brunhes (M-B) transition from two high-resolution loess-paleosol records. Journal of Geophysical Research, 115: B05101.

Yin, Q., 2013. Insolation-induced mid-Brunhes transition in Southern Ocean ventilation and deep-ocean temperature. Nature, 494: 222-225

Zeeden, C., Hambach, U., Obreht, I., Hao, Q., Abels, H.A., Lehmkuhl, F., Gavrilov, M.B., Marković, S.B., 2018. Patterns and timing of loess-paleosol transitions in Eurasia: Constraints for paleoclimate studies. Global and Planetary Change, 162: $1-7$.

Zheng, H.B., An, Z.S., Shaw, J., 1992. New contributions to Chinese Plio-Pleistocene magnetostratigraphy. Physics of the Earth and Planetary Interiors, 70: 146-153

Zhou, L.P., Shackleton, N.J., 1999. Misleading positions of geomagnetic reversal boundaries in Eurasian loess and implications for correlation between continental and marine sediment sequences. Earth and Planetary Science Letters, 168: 117-130.

Zhou, L.P., Oldfield, F., Wintle, A.G., Robinson, S.G., Wang, J.T., 1990. Partly pedogenic origin of magnetic variations in Chinese loess. Nature, 346: 737-739. 